\title{
Příběh Kőkenúrska v Amdu
}

\author{
Josef Kolmaš
}

\section{THE STORY OF AMDO KOKONUR}

ABSTRACT Location of the Kokonor region in Amdo. - Memorable places and personalities of the region. - Sumpa-khanpo Yeshepaljor (1704-1788), his life and work. - „The Annals of Kokonor“ (Mtsho-sngon-gyi lo-rgyus), 1786. - Translation. - Literature.

KEY WORDS Amdo; Kokonor; Sumpa-khanpo Yeshepaljor (1704-1788); “The Annals of Kokonor” (Mtsho-sngon-gyi lo-rgyus), 1786

\begin{abstract}
ABSTRAKT Lokalizace Kőkenúrska v Amdu (severovýchodní část provincie Čching-chaj). - Kőkenúrsko, jeho památná místa a významné osobnosti. - Sumpa-khänpo Ješepaldžor (1704-1788), život a dílo. - „Letopisy Kőkenúrska“ (Cchongöngji lurgjü), 1786. - Překlad. - Literatura. - Transliterace tibetských výrazů.
\end{abstract}

KLÍČOVÁ SLOVA Amdo; Kőkenúrsko; Sumpa-khänpo Ješepaldžor (1704-1788); „Letopisy Kőkenúrska“ (Cchongöngji lurgjü), 1786

\section{KÖKENÚRSKO V AMDU}

\section{Lokalizace}

Tak jak kdysi za časů G. J. Caesara byla „Gallia omnis divisa in partes tres“, dá se i o Tibetu říci, že se tradičně skládal ze tří územních částí: Ücang (Centrální Tibet), tvořený tzv. Předním Tibetem Ü a Zadním Tibetem Cang; Kham (Východní Tibet), pozdější čínská provincie Si-kchang 西康, dnes rozpůlená na západní část, připojenou $\mathrm{k}$ Tibetské autonomní oblasti, a východní polovinu, která je od roku 1965 součástí čínské provincie S’-čchuan 四川; Amdo, též Domä, čínsky An-tuo 安多 (Severovýchodní Tibet) neboli pozdější čínská provincie Čching-chaj 青海.

Provincie ČCHING-CHAJ (někdejší Amdo) se rozkládá na ploše 720000 km² na Čchingchajsko-tibetské náhorní plošině v západní Číně, dosahující průměrné nadmořské výšky 3000-5000 m. Je pramennou oblastí dvou největších čínských řek Čchang-tiang 長江 (Dlouhá řeka) alias Jang-c’-tiang 揚子江 a Chuang-che 黃河 (Žlutá řeka) a procházejí jí mohutná horská pásma Tchang-ku-la-šan 唐古拉山, Kchunlun-šan 崑崙山, Čchi-lien-šan 祁連山 ad.

$\mathrm{V}$ nejstarších dobách se tomuto území v čínské historii říkalo oblast obývaná etnickou skupinou Si-žung 西戎 („Západní Žungové“), za dynastie Chan 漢 (206 př. n. 1.-8 n. l. a znovu
25-220) oblast obývaná etnikem Čchiang 㒸, za Wang Mangovy 王莽 dynastie Sin 新 (9-25) zde byla zřízena prefektura Si-chaj-tün 西海郡 („Západní moře“), k níž za Suejů 隋 (581-618) přibyla prefektura Che-jüan 河源 („Pramen [Žluté] Řeky“).

Za Tchangů 唐 (618-907) a Sungů 宋 (960-1279) se území ŕíkalo Tchu-fan 吐蕃 (recte: Tchu-po 吐番) („Tibet“), za Jüanů 元 (1260-1368) byla severovýchodní část území pojmenována Kuej-te-čou 貴德州 („Kraj vzácné ctnosti“) a za Mingů 明 (1368-1644) se pro ně užíval název Si-fan 西 番 („Západní barbaři“).

Za mandžuské dynastie Čching 清 (1644-1911) se Čchingchaj postupně stal organickou součástí říše a k oficiálnímu zrrízení čínské provincie Čching-chaj došlo za Čínské republiky v roce 1928.

Jméno provincie je odvozeno od názvu největšího vnitročínského slaného jezera Čching-chaj-chu 青海湖 („Modré jezero"). Oblast obývají vedle Chanů (Číňanů) rozmanité původní menšinové nechanské národy a národnosti Tibetanů, Mongolů, muslimských Chuejů 回, türkických Salarů a dalších. ${ }^{1}$ Tibetané mají v současné době na území Čching-chaje zrrí-

1 Blíže o národnostní situaci na území Číny viz Dreyer 1976; Kolmaš 1980; Kolmaš - Malina 2005, 107-123; Mackerras 1995. 


\section{T I B E T}

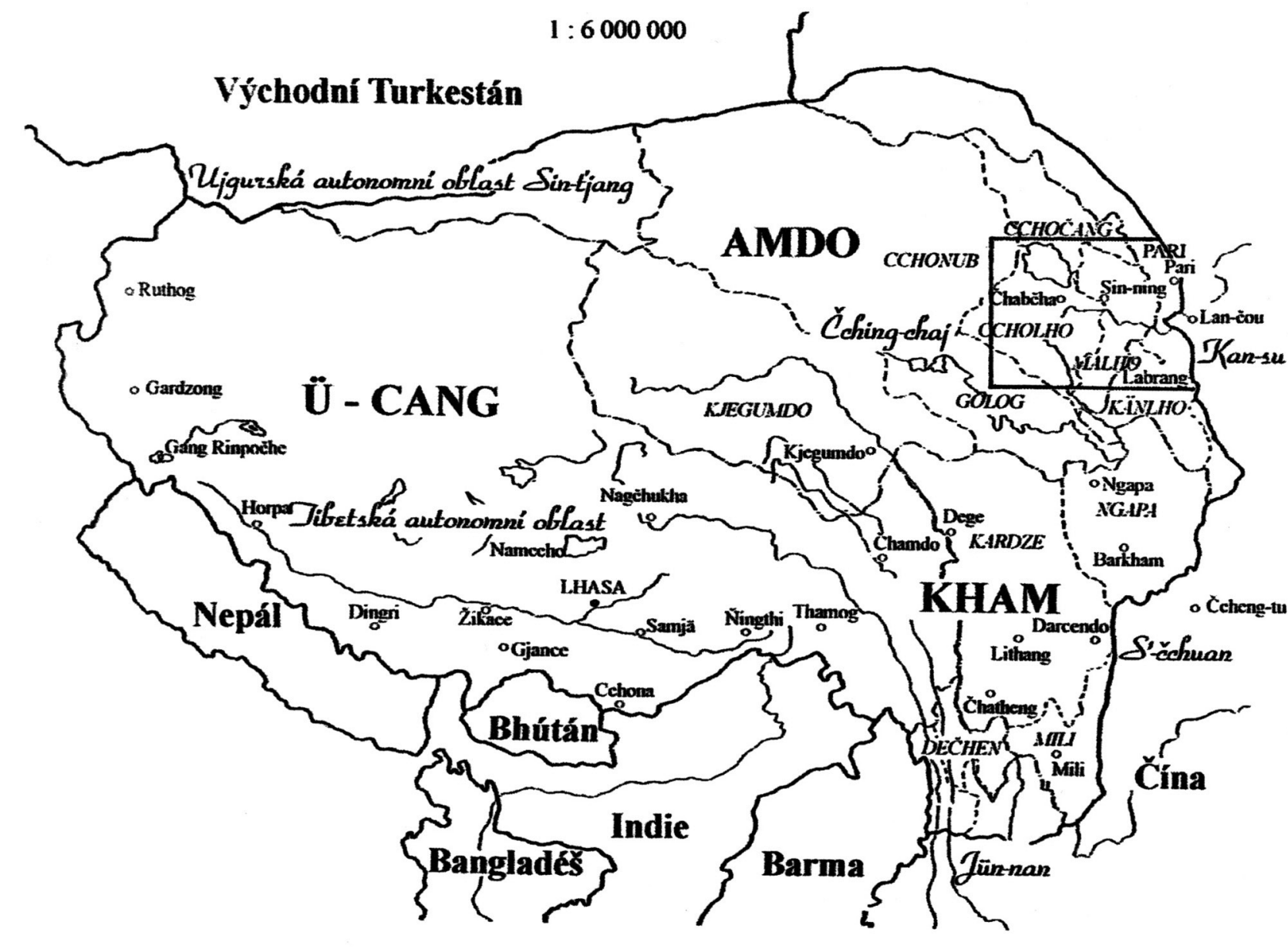

Obr. 1. Mapa etnického „Většího Tibetu“ se zakreslením území Kőkenúrska.

zeno pět „autonomních krajü“ - Chaj-pej 海北 (39 354 $\mathrm{km}^{2}$ ), Chuang-nan 黃南 (17 $921 \mathrm{~km}^{2}$ ), Chaj-nan 海南 (45 $\left.895 \mathrm{~km}^{2}\right)$, Kuo-luo 果洛 (76 $\left.312 \mathrm{~km}^{2}\right)$ a Jü-šu 玉树 (188 794 km²). Další dva Tibetské autonomní kraje Kan-nan 甘南 (čínsky Sia-che 夏河, $40201 \mathrm{~km}^{2}$ ) a Tchien-ču 天祝 $\left(6865 \mathrm{~km}^{2}\right)$ se nacházejí na teritoriu sousední čínské provincie Kan-su 甘肃.

Tradičním správním střediskem provincie Čching-chaj je Sining 西寧, kterým dnes prochází železnice spojující hlavní město ČLR Peking s administrativním střediskem Tibetské autonomní oblasti Lhasou. Další významnější místa jsou: Golmúd (Ke-er-mo 格尔莫), Jü-šu, Leng-chu 冷湖, Mangjaj 芒崖, Ta-čchaj-tan 大柴旦, kláštery Kumbum a Labrang (tento dnes v sousední provincii Kan-su) a př́rodní scenérie jezera Čching-chaj-chu s ostrůvkem Chaj-sin-šan 海心山 (tibetsky Cchoňingri), horstvo Amňemačhen, dvojice jezer Cchokjaring a Cchongoring, kde pramení Žlutá řeka (tibetsky Mačhu) ad.

Čching-chaj má podnebí vnitrozemské, léta studená, zimy suché trvající až 6 měsíců, sluneční svit dlouhý, roční deštové srážky 100-600 mm, v západním Čchaj-ta-mu 柴达木 (tibetsky Cchädam) nedosahují však ani $25 \mathrm{~mm}$.

KÖKENÚRSKO tvoří blíže teritoriálně nevymezené území severovýchodního cípu provincie Čching-chaj, jehož přirozeným centrem je jezero Čching-chaj-chu, mongolsky zvané Kőkenúr a tibetsky Cchongönpo - všechny výrazy s významem „Modré jezero“. Toto jezero, ležící přibližně mezi 99,5 až $100,7^{\circ}$ východní délky a 36,5 až $37,2^{\circ}$ severní šírky, sevřené horami Ta-tchung-šan 大通山, Ž'-jüe-šan 日月山 a Čchingchaj nan-šan 青海南山, v dávných dobách nazývané Si-chaj 西海 („Západní moře“), se rozlévá na ploše 4,583 km² v nadmořské výšce $3,195 \mathrm{~m}$. Jeho hloubka dosahuje $32,8 \mathrm{~m}$ a jeho vody jsou zásobovány od severozápadu řekou $\mathrm{Pu}$-cha-che 布哈河. V zimě jezero zamrzá. Jeho okolí tvoří rozlehlé pastviny. Uprošred jezera se nachází malebný ostrůvek Chaj-sinšan (tibetsky Cchoňingri, „Hora v srdci jezera“).

\section{Památná místa a významné osobnosti Kőkenúrska}

K pamětihodnostem Kőkenúrska patří především dva vel- 
kokláštery buddhistické školy Gelug ${ }^{2}$ - Kumbum (čínsky Tcha-er-s' 塔爾寺), založený v roce 1588 třetím dalajlamou Sönamgjamcchem, a Labrang (čínsky Sia-che), dnes v přilehlém Tibetském autonomním kraji Kan-nan v sousedním Kan-su, založený v roce 1709 prvním Džamjangžäpou Ngawangcöndüm (1648-1721). Památné je též „Cibulové údolí - Congkha, nedaleko od Kumbumu, rodiště zakladatele školy Gelug Congkhapy Lozangdagpy (1357-1419), a vesnice Tagccher pobliž Kumbumu, rodiště současného 14. dalajlamy a jeho šesti sourozenců.

Z území Kőkenúrska pochází celá plejáda předních představitelů Congkhapovy školy Gelug. Na prvním místě sám Congkhapa. Dále např́klad Ngawang Lozangčhödän (1642-1714), první pekingský metropolitní Čangkja-chutuchtu; ${ }^{3}$ Ngawangcöndü, známý též jako první Džamjangžäpa (1648-1721), zakladatel Labrangského kláštera, autor rozsáhlého literárního díla; historický spisovatel Sumpa-khänpo Ješepaldžor (1704-1788), autor dějin buddhismu v Indii, Č́ně, Tibetu a Mongolsku - Pagsam džönzang z roku 1748, a lokální historie rodného Kőkenúrska - Cchongöngji lurgjü z roku 1786 (podrobněji viz níže); Akja-chutuchtu Lozang Tänpägjalcchän (1708-1768), autor „Rodokmenů tibetských králů a ministrư“, v nichž líćí vývoj v zemi po rozpadu Tibetské ŕíše v 10. století; druhý Čangkja-chutuchtu Rolpädordže, známý též jako Lalitavadžra (1717-1786), důvěrník mandžusého císaře Čchien-lunga 乾隆 (1736-1795), znalec čínštiny, tibetštiny, mongolštiny a mandžuštiny, jazykový revizor mongolského překladu tibetského buddhistického kánonu Kandžuru a Tandžuru (1720-1749), autor či supervizor tibetského textu „Zrcadla mandžuského jazyka ve čtyřech jazycích“ - S'-tchi Čching wen-tien 四体清文鑑, totiž mandžuštiny, mongolštiny, tibetštiny a čínštiny (1771-1795); ${ }^{4}$ převtělenec kláštera Gungthang, gelugpovský spisovatel Tänpädönme (1728-1791), autor komentáŕů k pradžňápáramitovým ${ }^{5}$ textům; Lozang Čhökjiňima, známý též jako třetí Thukwan Dharmarádža (1732-1802), autor nábožensko-filozofického exkurzu dějinami buddhismu - Debther Šelgjimelong („Křištálové zrcadlo“) z roku 1802; Džigmesamtän (1803-1875), autor četných hagiografí;; významný amdoský vzdělanec Šerabgjamccho (1884-1968); Gendün Čhönphel

2 Gelug („Ctnostná řehole) - tzv. Žlutá škola tibetského buddhismu založená v 15. století Congkhapou. Jejím stoupencům se říká Gelugpa, někdy též Gedänpa („Ctnostní).

3 Čangkja - lokalita v Čching-chaji, od níž odvozují svůj název tzv. Čangkja-chutuchtové či tulkové sídlící v Pekingu. - Chutuchtu (staromongolsky chutughtu, novomongolsky chutagt) - významná buddhistická duchovní osobnost, její převtělenec (tulku). - Prvním pekingským Čangkja-chutuchtou byl Ngawang Lozangčhödän (1642-1714). Viz Chandra 1959, 26, 36-38; Kolmaš 2010b, 99-100.

4 S'-tchi Čching wen-tien, „Zrcadlo mandžuského jazyka“ - čtyřjazyčný mandžusko-mongolsko-tibetsko-čínský slovník z let 17711795. Blíže viz Kolmaš 2010a.

5 Pradžňápáramitá - různě obsáhlé mahájánské texty o „dosažení onoho břehu poznání pomocí transcendentální moudrosti“. V Tibetu tvoří součást Kandžuru.

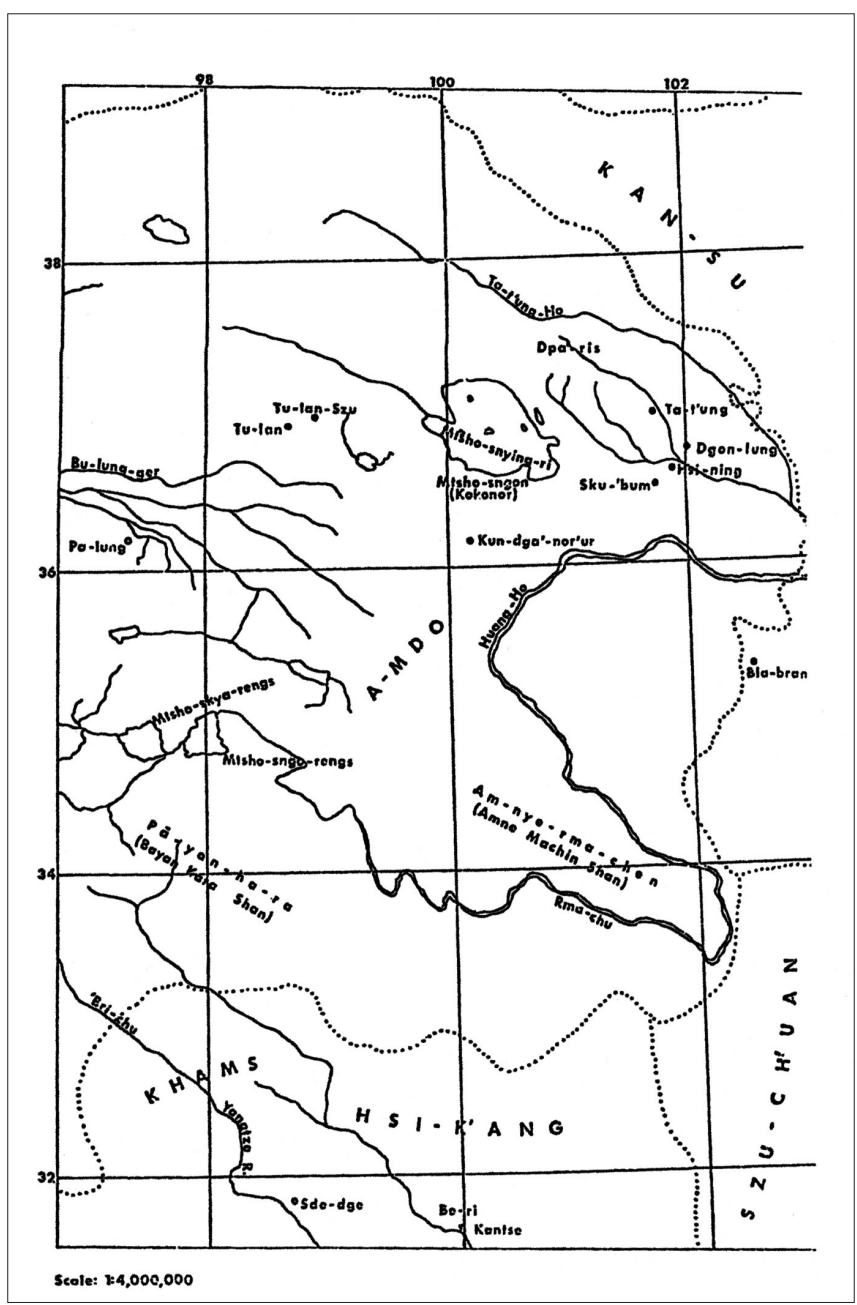

Obr. 2. Mapka Kőkenúrska.

(1905-1959), gelugpovský učenec, malíř, spisovatel a historik, autor moderně koncipovaných tradičních dějin Tibetu Debther karpo („Bílé anály“) z roku 1946; ${ }^{6}$ Tagccher-rinpočhe Thubtän Džigmenorbu (Thubten Jigme Norbu, 1922-2008), nejstarší bratr 14. dalajlamy, někdejší opat kláštera Kumbum, žijící od 50. let minulého století mimo Tibet, mimo jiné jako dalajlamův představitel $\mathrm{v}$ Japonsku; Tändzingjamccho (narozen 1935), 14. dalajlama, od roku 1959 zdržující se v Indii, laureát Nobelovy ceny míru (1989), autor četných prací o tibetském buddhismu a současném politickém vývoji v čínskotibetských vztazích; ${ }^{7}$ Čhökjigjalcchän alias Kalzangcchetän (1938-1989), 10. pančhenlama, významný činitel na tibetskočínské politické scéně.

6 Debther karpo - „Bílé anály“ autora Gendün Čhönphela (19051959) z roku 1946. Viz Kolmaš 2010b, 57, 67.

7 Čtrnáctý dalajlama Tändzingjamccho (narozen 6. 7. 1935). K jeho životu a dílu viz Svoboda $v$ exilu, Praha 1992 (reprint Praha 2011); Dekji Cchering, Můj syn dalajlama. Př́běh matky, Praha 2010; Moje duchovní pout žzivotem, Praha 2010; Kolmaš 2010b, 118. 


\section{J O U R N A L}

OF THE:

ASIATIC SOCIETY OF BENGAL.

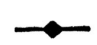

VOL. LVIII.

PART I. (History, ANTIQuities, \&C.)

(Nos. I to III.-1889 : with 10 plates; also a Supplement with 2 plntes.)

ELITED BY

THE HONORARY PHILOLOGICAL SECRETary,

CALCUTTA :

TRINTED AT THE BAPTIST MISSION PERSS,

AND PUBLISHED BY THE

ASIATIC SOCIETY, 57, PARK STREET.

1889.

\section{JOURNAL}

or Tne

\section{ASIATIC SOCIETY OF BENGAL. - \\ Part 1.-History, Literature, \&c.}

No. II. -1889 .

Lije of Sum-pa Khan-po, alsi siyled Yeses-Dpal-hbyor, the author of the liehumig (Chronological 'Table.)-liy Bábú Sarat Chasdia Das, C. I. $\mathbf{E}$.

This great Lama was born in the year $1702 \mathrm{~A}$. D. (Tree-monkey of the 12th ejele of 60 gears) at a place in the neighbourhood of the $D_{\text {gon-lun }}$ monastery of Amdo in ulterior 'libet. He is better known by his family name of Sum-pa, which means one from the country of Sum, a province in Wester"n Tibet. In his infancy he is said to have given indications of his identifying himself with the spirit of his predecessor. While very young he learnt to read and write with extraordinary facility. He became well known by the name of Sumpa-Shabs-drun He was admitted into the monastery of 1 gon-lun in the 9 th yenr of his nge. He received instruction in the sacred literature of the Buddhists under Lchan skya Riupo-chhe Nag-Dran chlos ldan) and Thu Kwan chhos kyirzya-mtsho and other great Lamas. From Lchañ.skyn ho received tho vows of monkhood, who gave him the name Yeses Dpal hbyor. He studied metaphysics, loric, rhetoric, poetry, Buddhist liturgy, ritunl, and tho dogmatical and theoretical differences of the various Buddhist schools. He also lenrnt arithmetic, medicine, the science of vocal music, the works on Sútras and Tantras, and the art of sacred painting. With tho acquisition of all this learning he was oecupied till the twentieth year of his age. In addition to acquiring all the virtues and talents of his predecessor, he gined the highest proficiency in astronomy, astrology aud the science

Obr. 3. Začátek S. Č. Dásova textu „Life of Sum-pa Khan-po“, JASB LVIII, Pt I. (Das S. Ch., 1889, p. 37).

\section{SUMPA-KHÄNPO JEŠEPALDŽOR (1704-1788)}

\section{Život}

Sumpa-khänpo („Učenec ze Sumpy“) alias Sumpa-khänčhen („Veleučený ze Sumpy“), národnosti monguorské, ${ }^{8}$ pocházel ze starého prototibetského kmene Sumpa, ${ }^{9}$ obývajícího v drrivějších dobách oblast Centrální Asie a severního Tibetu. Podle jeho vlastních „Letopisů Kőkenúrska“ se narodil v muž-

8 Monguor - mongolská národnost žijící na hranicích Kan-su a Čching-chaje mezi řekami Si-ning-che 西寧河 a Ta-tchung-che 大通河. Jejich jazyk má nejblí̌̌e k západomongolským (ojratským) nářečím. Rozšířená mezi nimi, zejména ve vzdělaneckých vrstvách, je však i tibetština a čínština. Viz A. Mostaert, The Mongols of Kansu and their language, Bulletin of the Catholic University of Peking 8 (1931), 75-89; Kolmaš - Malina 2005, 119.

9 Sumpa - jeden $\mathrm{z}$ dávných tibetských kmenů žijících na horních tocích řek Dičhu a Dzačhu na Tibetské náhorní plošině. Viz Tarthang 144-146. ském roce Dřeva a Opice třináctého šedesátiletého cyklu, ${ }^{10}$ tj. 1704 , v osadě Tholi při březích řeky Mačhu v Amdu. Podle S. Ch. Dásových chronologických tabulek v jeho „Life of Sumpa Khan-po“ (1889), str. 37, je mylně uváděn rok 1702 a místo narození poblíž buddhistického kláštera Gönlung v téže lokalitě.

Nadaného hocha čekala skvělá duchovní kariéra. V roce 1712 byl přijat do noviciátu v Gönlungském klášteře, kde na jeho duchovní formaci dohlíželi učitelé Lozangješe a Džampalgjamccho z nedalekého velkokláštera Kumbum a dále dva

10 Šedesátiletý cyklus - tibetsky rabčhung, používá kombinaci dvanácti zviŕat čínského zodiaku (myš, vưl, tygr, zajíc, drak, had, kůn̆, ovce, opice, pták, pes, vepř) s pěti „prvky“ (dřevo, oheň, země, železo, voda). Každý „prvek“ se opakuje dvakrát v kombinaci s dvěma za sebou jdoucími zvírraty. Sudé roky jsou z astrologických důvodů označovány jako „mužské“, liché jako „ženské“. První šedesátitiletý cyklus začal v Tibetu ženským rokem Ohně a Zajíce v roce 1027. V práci zmiňované události se vztahují k cyklům X. (léta 1567-1626) až XIII. (léta 1747-1806). Blíže viz Kolmaš 2010b, 162-167. 
АКАДЕМИЯ НАУК ССCP

СИБИРСКОЕ ОТ ДЕЛЕНИЕ

БУРЯТСКИИ ФИЛИАЛ

БУРЯТСКИИ ИНСТИТУТ ОБЩЕСТВЕННЫХ НАУК

P. Е. ПУБАЕВ

„ПАГСАМ-ЧЖОНСАН“ -

ПАМЯТНИК

ТИБЕТСКОЙ

ИСТОРИОГРАФИИ

XVIII BEKA

Ответственный редактор

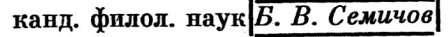

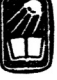

И З Д А Т Е Л ВСТ В

СИБИРСКОЕ ОТДЕЛЕНИЕ

Новосибирск • 1981

Obr. 4. Titulní list R. J. Pubajevovy práce „Pagsam-čžonsan“(Pubajev 1981a).

„převtělenci“ tulkuové ${ }^{11}$ - Čangkja-chutuchtu Ngawangčhödän (1642-1714), který mu také udělil osobní jméno Ješepaldžor („Moudrost a Hojnost“), odpovídající sanskrtskému Džňánašríbhúti, a Thukwan-chutuchtu Ngawang Čhökjigjamccho (1680-1735). U svých učitelů studoval na základě súter a tanter též buddhistickou metafyziku, logiku, rétoriku, poetiku, liturgii a rituál, jakož i dogmatické a teoretické rozdíly mezi různými školami tibetského buddhismu. Kromě toho se věnoval též astronomii, astrologii a malování náboženských ikon. Své první mnišské sliby složil u Čangkja-chutuchty.

Další studia v rodném Kőkenúrsku přerušilo v roce 1723 povstání chošúdského ${ }^{12}$ prince Lozangtändzina, jemuž padl za obět i Gönlungský klášter a ostatní kultovní místa. Sumpa-khänpo v té době odešel do Centrálního Tibetu (Ücang)

11 Tulku - buddhistický duchovní, do něhož je převtělena nějaká vynikající zesnulá osobnost. Blí̌ze viz Kolmaš 2009, 199-200.

12 Chošúd (staromongolsky Chosighud) - západomongolský kmen. - Lozangtändzin byl synem Gušrichanova desátého syna Tašibáthura Tändzinčhögjala, který vyvolal povstání v Kőkenúrsku proti čínské správě, které v roce 1724 potlačila mandžuská vojska (viz poznámku 158).

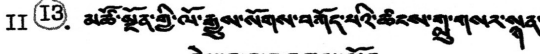

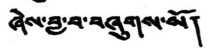 Прекраснве мотивы и'з песни брахман (Исторшя Кукунора)}

Повествованше в "Истории Кукунора" делштая на четвре гвавы или раздела, которве Сумба-канбо назнвает четнрымя основвми вопpocamm.

I. Јегенди о возникновении Кукунора. Здесь пршводятся два предания, бнтушие в народе.

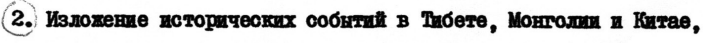

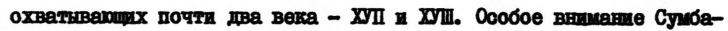
канбо уделяет пстории Тибета.

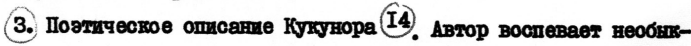
новенные ботатства области и красоту ее пршоді.

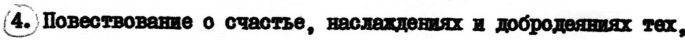

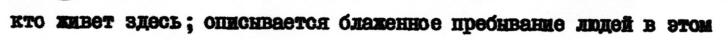

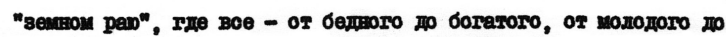

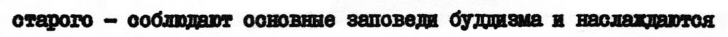
oчracrsen.

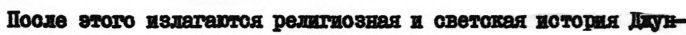

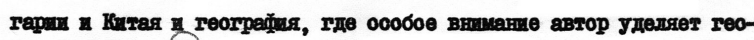
Ipeinan Troera (I5).

I9 moros.

I3 0 том, что этот труд имеет в томе порядвовы $\mathrm{II}$, см. Bume crp.I2.

(I4) Современная провинпвя Iинхай в КнР.

I5)

I5 Б. Д. Дандароном законсен в основном перевод әтого труда ва

pyccrent язвк.

Obr. 5. Bibliografický záznam o „Análech Kőkenúrska“v B. D. Dandaronově Opisanije tibetskich rukopisej (Dandaron 1965).

- není známo, zda již před vypálením Gönlungu, nebo až po něm -, kde se přihlásil ke studiu na klášterní univerzitě v Däpungu. U osobního lékaře (lamän) 5. dalajlamy Ngawang Lozanggjamccha (1617-1682) Rawaphugpočheho a dalšího mänrampy (léčitele) Ňimagjalcchäna zde studoval teorii a praxi tibetské medicíny podle traktátu Sorig gjüži („Čtvero medicínských tanter") ${ }_{13}^{13}$ dále nauku o tibetském kalendáři ${ }^{14} \mathrm{a}$ indické (cikar) a čínské (cinag) chronologii, gramatiku (sumtag) a poetiku (ňänngag). Na závěr úspěšného studia získal učený titul Sumpa-pandita („Pandita ze Sumpy“).

Za pobytu v Centrálním Tibetu navštívil v roce 1725 také klášter Tašilhünpo ${ }^{15} \mathrm{v}$ Zadním Tibetu (Cang), kde v přítomnosti 5. pančhenlamy Lozangješeho (1663-1737) složil poslední řeholní sliby a v roce 1726 byl jmenován khänpem (zde: „děkanem“) na učilišti Gomang, jednom ze čtyř däpungských fakult ${ }^{16}$. Svého pobytu v Centrálním Tibetu využil také k ná-

13 Sorig gjüži („Čtvero medicínských tanter“) - základní dílo tibetské lékařské a farmakologické literatury autora Juthog Jöntängönpa (1127-1203). Viz Kolmaš 2010b, 75.

14 Tibetský kalendár - viz poznámku 10.

15 Tašilhünpo - velkoklášter školy Gelug poblíž Žikace, založený $\mathrm{v}$ roce 1447. Tradiční sídlo pančhenlamů.

16 Gomang - gelugpovský klášter Däpung je tvořen čtyřmi da- 


\section{TRANSCRIPTION OF TEXT}

(p. 429, line 13) //Rtsa ba'i gnyis pa ni/ Gna' sngon gang sus yul de bdag byas pa'i yi ge bdag gis ma mthong la/ 'on kyang snga dus su sa stong lta bu la su 'dug gi nges pa med dam snyam/ bar skabs nas bod dpa' ris kyis bdag byas tshe phur tsha sgam pa chos rdo rje zhes pa'ang byung nas mtsho snying ri sogs la bsdad/ dpa' ris kyi rjes su bod a chi'i dpon rta mang po yod pa la khri rta dmar can du grags pa 'bangs bcas kyis ljongs (Origo: ljogs) de la dbang bsgyur dus su glang dkar po zhon nas 'gro ba'i bla ma glang dkar can zhes pa grub pa thob pa lta bu zhig mtsho snying dang mtsho'i nub (Origo: zhub) 'gram gyi mgon po gdong zhes pa'i brag khung dang/ khro bo lta bu dang bskang rdzas 'dra ba rang byung du ma yod pa'i brag bar sogs su bsdod pa'ang byung/ yang bar der bod co ni'i mi sde zhig dang/ phyis su len tan hu thog thu yar 'ongs nas lam du 'das rjes su ru sde 'thor ba'i nang gi cha gwar sde tshan zhig kyang rma chu khar bsdad de sa mkhar bzung nas zhing btab zer/ de ltar na sngar rgyal dpon chen po kho nas bdag byas pa'i nges pa med pa 'dra/ de nas thu med ho lo che dpon spun 'bangs bcas yun ring bsdad/ de dus (p. 430) su rgyal ba gnyis pa rje blo bzang grags pa'i dge lugs zhwa ser ba'i bstan pa dri ma med pa bod dang bod chen dang sog yul du dar rgyas che la/ de'i nang nas de la snying nas dad pa byang stod kyi sog po o rod (Origo: rong) tsho bzhi dang/ bar du bod chen gyi a mdo dpa' ris sogs dang/ smad kyi sog po mon gwol phal cher yin la/ de la mi dad par bod kyi chos lugs gzhan

Obr. 6. Transliterovaný tibetský text vstupní části „Análů Kőkenúrska“ (Yang $1969,10)$

vštěvě kraje Lhokha v sousedství Bhútánu, spojené s poutí do nejstarší tibetské buddhistické svatyně a kláštera Samjä jihovýchodně od Lhasy z poloviny 8 . století. ${ }^{17}$

$\mathrm{V}$ roce 1731 se po dlouhých osmi letech, $\mathrm{z}$ toho po pěti letech ve funkci khänpa Gomangu, vrátil do rodného Amda, kde už byl mezitím opraven vypálený klášter Gönlung. Sám pak v roce 1733 dal podnět k založení kláštera Šädubling pro zhruba osmdesát mnichů v místě staré poustevny Samtänling. V roce 1737 mu přišlo od čtvrtého mandžuského císaře Čchien-lunga pozvání k návštěvě Pekingu, kam ho doprovázel věhlasný již tehdy amdoský učenec druhý Čangkja-chutuchtu Rolpädordže. V říšském hlavním městě pak zůstal v klášteře Cchodüngön („Klášter sedmi moří) celkem pět let a věnoval se spolu s Rolpädordžem práci na revizích tibetských knih tištěných v Pekingu. Za tuto úspěšnou práci byl císařem poctěn titulem erdeni pandita („,zzácný pandita“) s diplomem na žlutém hedvábu.

V roce 1743 odešel na tři roky na vyhledávané čínské buddhistické poutní místo Wu-tchaj-šan 五台山 („Hora pěti

cchangy („fakultami“), z nichž Gomang je dacchang „bohoslovecký“.

17 Samjä - starobylá svatyně a klášter asi $150 \mathrm{~km}$ jihovýchodně od Lhasy, založený Padmasambhavou v 8. století. Viz Kolmaš 2009, 179. teras“) v severočínské provincii Šan-si 山西, kde je uctíván bódhisattva Maňdžušrí (čínsky Wen-šu pchu-sa 文殊菩薩). ${ }^{18}$ Po návratu do Amda v roce 1746 byl ustanoven opatem (khänpo) Gönlungského kláštera a dále se věnoval svému dílu o tibetské chronologii. Jsa nespokojen s dosavadními tibetskými pracemi o astronomii, astrologii a chronologii, shromáždil na dvacet těchto děl od různých autorů, porovnal je mezi sebou, přičemž za nejspolehlivější uznal práci Čhödžung („Původ Nauky“) ${ }^{19}$ starotibetského polyhistora Butön Rinčhenduba (1290-1364). Na základě komparativního studia vytvořil své vlastní chronologické dílo Pagsam džönzang („Dobrý strom splňující přáni“), představující dějiny buddhismu v Indii, Číně, Tibetu a Mongolsku v časové posloupnosti, na kterém začal pracovat již v roce 1736 a které dokončil v roce 1748. Dílo se stalo na mnoho let standardní prací v tomto oboru. ${ }^{20}$ Dále sepisoval své četné práce různého rozsahu o tibetské astrologii, medicíně, geografii a historii. V roce 1786 napsal své poslední dílko „Letopisy Kőkenúrska“ - Cchongöngji lurgjü. ${ }^{21}$

Za dva roky nato, $v$ mužském roce Země a Opice třináctého šedesátiletého cyklu, tj. 1788, ve věku 85 let v klášteře Gönlung zemřel.

\section{Dílo}

Prvním, kdo do světové vědy uvedl jméno Sumpa-khänpa Ješepaldžora a jeho originální dílo Pagsam džönzang, byl bengálský tibetolog Bábú Sarat Chandra Dás (1849-1917) v práci „Life of Sum-pa Khan-po, also styled Yeśes -Dpal-hbyor, the author of the Rehumig (Chronological Table)“, uveřejněné $\mathrm{v}$ Journal of the Asiatic Society of Bengal, Vol. LVIII, Part I. (History, Antiquities, etc.), Calcutta 1889, 37-84. Práce je anglickým překladem díla Chronologické tabulky pro léta 1026-1745 (s dnešními kalkulacemi se autor rozchází o dva roky; správně má být 1024-1743).

Pokud je mi známo celé Sumpa-khänpovo dílo (sungbum) existuje v xylografických tiscích z Kőkenúrska, chovaných v Library of Congress (Coll. Rock) a také v mongolské Státní knihovně v Ulánbátaru. Poprvé tibetský originál Pagsam džönzangu zveřejnil indický tibetolog Lokesh Chandra z International Academy of Indian Culture v jím vydávané edici Śata-pițaka, 8, New Delhi 1959.

Popis jednotlivých titulů Sumpa-khänpových Sebraných spisů (sungbum), pod záhlavím Ješepaldžor Sumpa-pandita-khänpö

18 Maňdžušrí - tibetsky Džampal, bódhisattva, ztělesňující nejvyšší mystickou moudrost. V Číně uctíván na „Hoře pěti teras“ Wutchaj-šan. Viz Kolmaš 2009, 88-89 a 159.

19 Čhödžung („Původ Nauky“) - vrcholné dílo tibetské historiografie autora Butön Rinčhenduba (1290-1364) z roku 1322. Viz Kolmaš 2010, 45 a 52 .

20 Pagsam džönzang („Dobrý strom splňující přáni“) - Sumpakhänpovo vrcholné dílo z roku 1748. Viz Kolmaš 2010b, 102 a 114115.

21 Cchongöngji lurgjü („Historie Kökenúrska“) - autora Sumpakhänpo Ješepaldžora z roku 1786. Viz Kolmaš 2010b, 48 a 114-115. 
Sungbumgji karčhag („Soupis Sebranýh spisů pandity Sumpakhänpa Ješepaldžora“), doplněný stručným technickým a částečně i obsahovým popisem podal Lokesh Chandra ve svých Materials for a History of Tibetan Literature [Śata-pițaka, 29 (2)], New Delhi 1963, 49-50. Lokesh Chandrova edice obsahuje v osmi svazcích (KA - ŇA) a Dodatcích dohromady 92 bibliografických jednotek. Přepis tibetských titulů je podán tamtéž na str. 477-481.

Podle jiného exempláře Sumpa-khänpových děl uloženého v Tibetském fondu Burjatského institutu v Ulan-Ude se v týchž osmi identických svazích Sumpa-khänpových Sebraných spisů nachází celkem 69 bibliografických položek. Přepis názvů jednotlivých děl $\mathrm{z}$ tohoto exempláře spolu $\mathrm{s}$ jejich překladem do ruštiny doplněným poznámkami vydal Bidija Dandarovič Dandaron (1914-1974) ve své práci Opisanije tibetskich rukopisej i ksilografov Burjatskogo kompleksnogo naučno-issledovatěl'skogo instituta, Vypusk II, Moskva 1965, 18-54.

Mezi Sumpa-khänpovými díly jsou např́íklad tato (odkazováno na jejich číslování u Dandarona):

„Dějiny buddhismu v Indii, Č́ně, Tibetu a Mongolsku“ Pagsam džönzang (I/1, 317 fol.); ;2

„Stručné vylíčení světa“ - Dzamling čišä, obsahující geografii Indie, zejména míst Buddhova pozemského působení, dále Číny, Tibetu a Mongolska, jakož i bájné země Šambhaly (II/10, 14 fol.);

Letopisy Kökenúrska“ - Cchongöngji lurgjü (II/11, 14 fol., podrobněji viz níže); ${ }^{23}$

Rozbor a komentáŕ díla 4. pančhenlamy Lozang Čhökjigjalcchäna (1570-1662) Lama čhöpä čhoga („Obřad klanění se učiteli“) (III/2, 62 fol.);

Výklad učení mádhjamiků ${ }^{24}$ (III/6 a 7,, $12+4$ fol.);

Výtah ze sútry Šerab ňingpo („Jádro transcendentální moudrosti“') $)^{25}$ (III/8, 18 fol.);

Traktát o dosahování dlouhověkosti (cchepagme) (IV/3, 18 fol.);

Rukovět tantrického mystického rituálu phur ${ }^{26}$ (IV/12, 35 fol.);

Výklad slov modlitby pro přechod nebezpečenstvími posmrtného stavu bardo ${ }^{27}$ (IV/13, 11 fol.);

22 Viz poznámku 20.

23 Podle Dandarona 22-23 a 24, poznámka 15, má mít [Dandaron] „, podstatě hotový překlad tohoto díla do ruštiny“. Autoru (JK) se nepodařilo tuto informaci ověrit.

24 Mádhjamika - mnich mahájánské školy madhjamaka, „školy stř̌edu" (tibetsky uma).

25 Šerab ňingpo - mahájánská sútra, jejímž tématem je nauka o prázdnotě (sanskrtsky šúnjata, tibetsky tongpaňi) a jejích konkrétních projevech $\mathrm{v}$ etické rovině. Viz Jádro transcendentální moudrosti, Praha 1992.

26 Phur, též phowa - přenesení vědomí („ejekce, vystřelení ${ }^{\prime \prime)}$, speciální technika přenesení vědomí skrze otvor v temeni hlavy praktikovaná jóginy v hodině smrti, mající jim zajistit znovuzrození v podobě, kterou si sami přejí. Viz Tibetská kniha mrtvých, 35, poznámka 6.

27 Bardo - viz „Modlitba za vysvobození z nebezpečných cest bar-
Objasnění základních tezí tantrických metod dosahování vysvobození (dol) a duchovního osvícení (čhangčhub), podle Congkhapových spisů Lamrim čhenpo a Ngagrim čhenpo ${ }^{28}(\mathrm{~V}$, 417 fol.);

Vyložení základních tezí buddhismu, obsažených ve dvou Congkhapových výše uvedených pracích (VI, 405 fol.);

Pět medicínských (sorig) traktátů (VII/1-5, $20+47+38+7$ +49 fol.);

Tři pojednání o indické (kar, „bíléc) a čínské (nag, „černé“) astrologii (ci) (VII/6-8, $69+93+26$ fol.);

O skapulimancii čili věštění podle ovčích lopatkových kostí (luggi sogpa) (VII/9, 4 fol.);

Dvě pojednání o poetice a verzologii (ňänngag) (VII/10-11, $5+46$ fol.);

Dvě pojednání o korespondenčním stylu (jigkur) (VII/12-13, $69+22$ fol.);

Dva traktáty o pravidlech mnišského chování (VIII/1-2, 52 +18 fol.);

Ukázka Sumpa-khänpovy korespondence s 6. pančhenlamou Lozang Paldänješem (1738-1780) formou „otázek a odpovědí (dilän nebo žulän) o rozmanitých problémech historie, náboženství, mystiky, filozofie, k problému eposu o Gesarovi aj. (VIII/4, 100 fol.);

Biografie Sumpa-khänpa do 73. roku jeho věku, tj. do roku 1776 , napsaná $z$ jeho podnětu žáky, a soupis všech jeho prací ${ }^{29}$ (VIII/5 a 7, $294+12$ fol.);

Pojednání o prohlídce koní (tačä) podle indické metodiky (VIII/8, 5 fol.).

\section{CCHONGÖNGJI LURJÜ (LETOPISY KÖKENÚRSKA), 1786}

\section{Struktura a obsah díla}

Zatímco Pagsam džönzang je Sumpa-khänpovým nejvýznamnějším a také nejznámějším dílem, patři jeho „Letopisy Kökenúrska“ - celým titulem metaforicky zvané Cchongöngji lurgjü sog köpä cchanglu sar ňän („Nová píseň Brahmova tvořená Letopisy Kőkenúrska“) - k drobnějším dílkům spíše lokálního charakteru a významu.

Dílko vyšlo tiskem poprvé v roce 1960, zařazeno za Sanggjägjamcchovy (1653-1705) dějiny gelugpovských klášterů. Vaidúrja serpö melong („Zrcadlo ze žlutého lapisu lazuli“) ${ }^{30}$, vydané Lokeshem Chandrou v ediční řadě Sata-pițaka, 12 (2), 425-458.

dem“, Tibetská kniha mrtvých, str. 147-151.

28 Lamrim čhenpo - viz Lam-rim Čen-po (Stěpeni puti k blažen$s t v u)$. Díl I: Mongolskij perevod, Vladivostok 1910; Díl II: Russkij perevod s predislovijem i primečanijem G. C. Cybikova, Vladivostok 1913.

29 Chandra 1963, 477-481; Dandaron, 18-54

30 Sanggjägjamccho-1653-1705, politik, regent (desi) Tibetu, autor prací lékařských, astrologických a právnických, mimo jiné i dějin školy Gelug spolu s kronikou kláštera Gandän, Vaidúrja serpö melong. Viz Kolmaš 2010b, 111-112. 


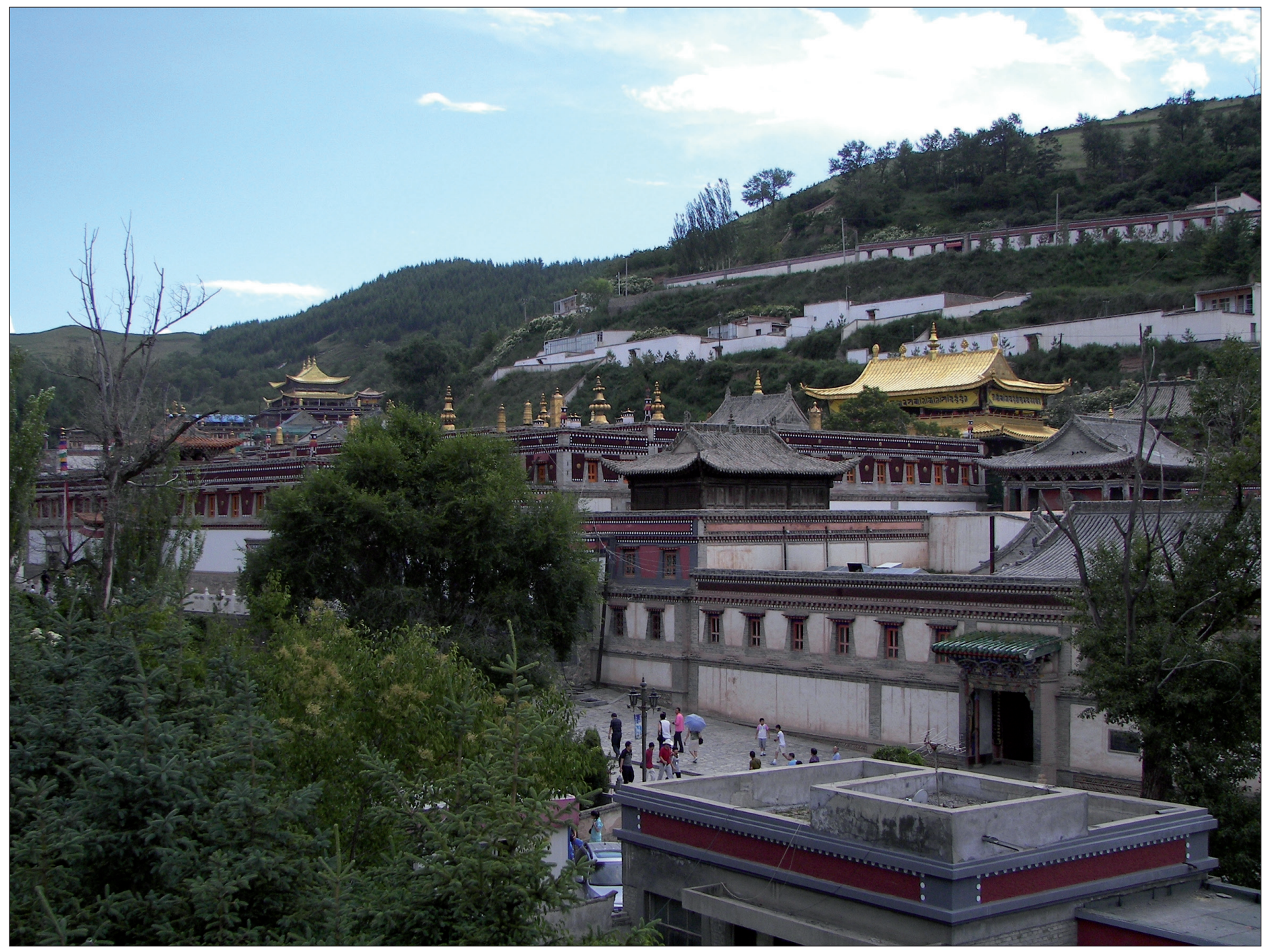

Obr. 7. Klášter Kumbum Čhampaling (čínsky Tcha-er-s’ 塔爾寺) u Si-ningu (provincie Čching-chaj) - hlavní shromaždovací síň kláštera. Kapli postavenou na místě Congkhapova narození kryje pozlacená stř̌echa. Foto Jakub Hrubý.

Dílko tvoři čtyři kapitoly:

Kapitola I (str. 427-429) - legenda o původu jezera Kökenúr kolující mezi místními lidmi. Autor přitom vyjadřuje některé své nesouhlasné názory s touto legendou.

Kapitola II (str. 429-445) - vlastní historický př́běh Kökenúrska a souvisejíć s ním historické události v Tibetu, Mongolsku a Číně v 17.-18. století (viz zde Překlad).

Kapitola III (str. 445-450) - básnický popis Kökenúrské země, jejího bohatství a prírodních krás.

Kapitola IV (str. 450-452) - O blahu a požehnání těch, kdo žijí v tomto „pozemském ráji“, kde se všichni - od chudých po bohaté, od mladých po staré - ř́dí základními př́kazy Buddhova učení a čerpají z něho pro sebe štěstí.

Na závěr (str. 452-458) je stručně vyložena náboženská a světská historie Džúngarska ${ }^{31}$ a Číny, v níž je zvláštní pozornost věnována geografii Tibetu.

V kolofonu (str. 458) se vyzvedá autorova hluboká úcta

31 Džúngarsko - území historického Čínského Turkestánu. Původní země ojratských Mongolů, k nimž náležel Gušrichan. ke Gušrichanovu ${ }^{32}$ potomstvu, v posledním století vládnoucímu Kőkenúrsku. Vyslovuje se dík jakémusi Marmedzä Ješemu za pomoc při obstarávání pramenné literatury. Připomíná se, že nástin práce původně napsal ručně cünčhung [novic] Lozangtänphel a jeho konečnou verzi do dřevěných matric vyryl gecchul [mladší mnich] Lozangcöndü.

Kőkenúrsko bylo již od počátků mandžuské vlády v Číně v 17. století známé jako pastevecké území mongolského kmene Chošúdư ${ }^{33}$ a jmenovitě jejich vůdce „krále Tibetu“ Gušri-

32 Gušrichan (staromongolsky Gosichan, novomongolsky Güšchan) - 1582-1655, potomek v devatenácté generaci Čingischánova bratra Chabutu Chasara, vládce mongolských Chošúdů, jedné z větví západomongolských Ojratů. Po přesunu svého kmene do Kőkenúrska se zapojil do bojů proti tibetské dynastii Cangpa (1565-1642), pomohl pátému dalajlamovi k získání světské moci ve Lhase a založil vlastní dynastii chošúdských Mongolů v Tibetu (1642-1717). U Tibetanů zván Tändzinčhögjal a Kőkenúřané ho považují za svého národního hrdinu.

33 Chošúd (staromongolsky Chosighud) - západomongolský kmen, k němuž náležel Gušrichan. 


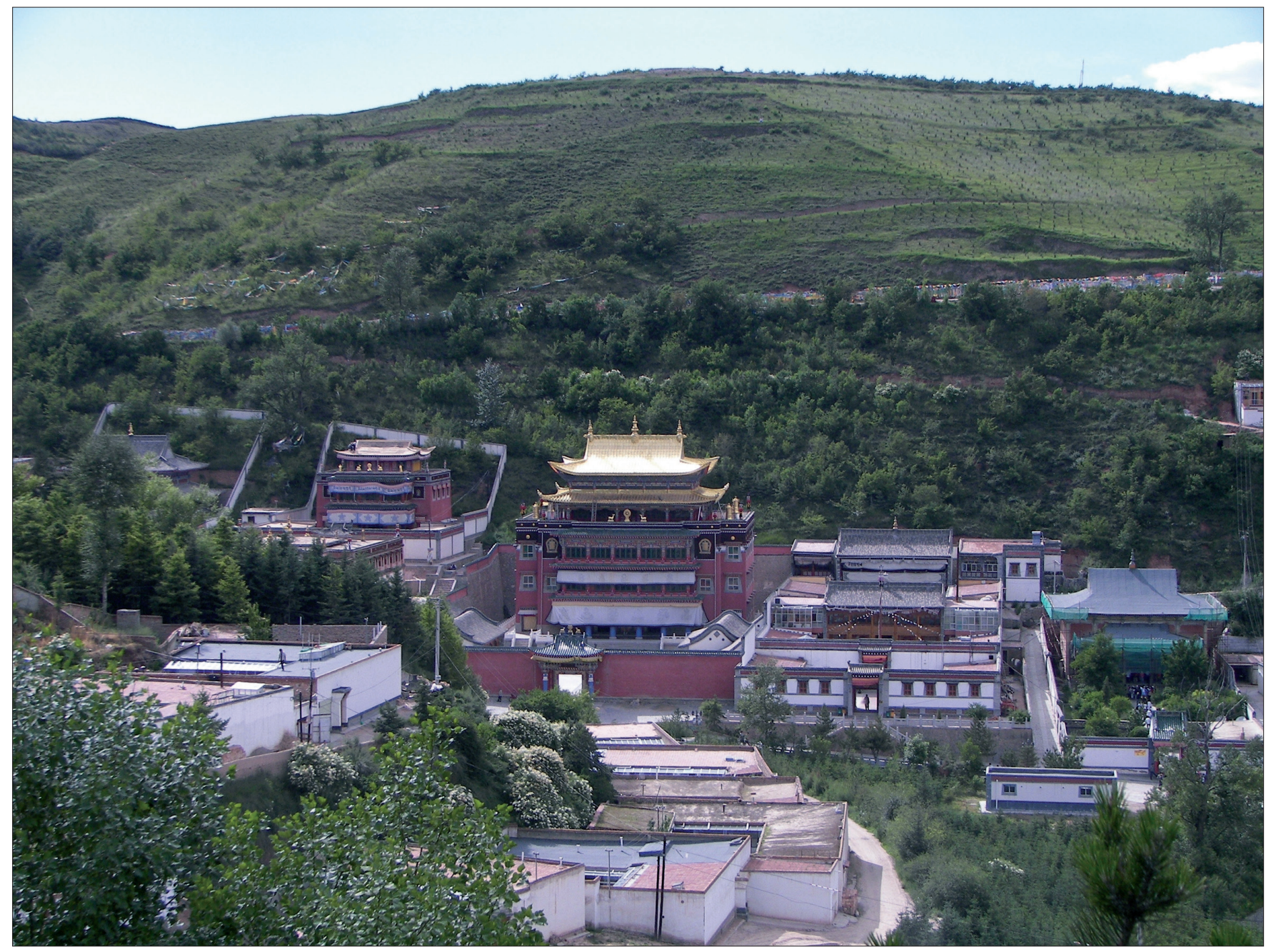

Obr. 8. Část areálu kláštera Kumbum Čhampaling s jednou z kolejí a novou síní vystavěnou před několika lety na náklady jednoho z převtělencủ kláštera, který v současné době žije v indickém exilu. Foto Jakub Hrubý.

chana (1582-1655) a jeho potomstva. Ti odvozovali svůj rod od Čingischánova mladšího bratra Chazara. Sumpa-khänpovy „Letopisy Kőkenúrska“ jsou tak apoteózou Gušrichanova rodu a celého období Chošúdského panství v Tibetu (16421717). Vlastně pro tento rod autor dílo psal a jemu je také celé věnoval.

Gušrichan dobyl Tibet pro Žlutou sektu Gelug na domácí dynastii Cangpa (1565-1642) v roce 1642 a takto dobytou zemi jako svůj „náboženský dar“ věnoval 5. dalajlamovi Ngawang Lozanggjamcchovi (1617-1682). Sumpa-khänpo, i když výchovou gelugpovec, etnicky však jako Monguor bližší Chošúdům, byl Tibetany nahlížen jako „cizák“. Zalíbení v Gušrichanovi u něj tak zcela přirozeně převážilo nad obdivem k „Velkému Pátému“ dalajlamovi, o němž se ve své práci zmiňuje jen sporadicky, aniž by blíže hodnotil jeho úlohu v tibetských dějinách.

„Letopisy Kőkenúrska“ jsou nedocenitelnými dějinami země Kőkenúrské, nebot’ byly napsány učeným lamou zrozeným a svou činností spjatým s Kőkenúrskem. Pokud jde o historická fakta a data, vyniká dílo vysokým stupněm přesnosti a spolehlivosti a nachází potvrzení v dobových čínských a ti- betských pramenech. Navíc na rozdíl od jiných tibetských historiků nezdůrazňuje tolik náboženské události. Rovněž jeho jazyk - spisovná tibetština - je zřetelný a jasný. Jeho výpravný styl je místy tradičně tibetsky obrazný a básnivý. Autor občas projevuje zálibu $v$ květnaté mluvě a lidových rčeních a příslovích. Důkaz to toho, že chtěl, aby jeho Kőkenúřané dobře porozuměli historii své země a získali k ní lásku.

Žánrově patří dílko do tibetské historické literatury kategorie lurgjü („letopisy, anály“, Kolmaš 2010b, 18). Na rozdíl však od jiných prací tohoto druhu je vybudováno na principu osobní autorovy výpovědi (časté ,jác, „můj” apod.).

Následující překlad je pořízen $\mathrm{z}$ transliterovaného tibetského textu, který uveřejnil Yang 1969, 11-28.

Technická poznámka: a) Otazník v kulatých závorkách za slovem (?) značí, že dotyčné osobní či místní jméno nebylo autorem identifikováno; b) Slova $\mathrm{v}$ hranatých závorkách [ ] jsou autorem ze stylistických či věcných důvodů přidána; c) Text vysázený kurzívou a vložený do složených závorek představuje původní poznámku či doplněk tibetského autora; d) Pravopisná podoba tibetských slov je uvedena v části „Transliterace tibetských výrazů“. 


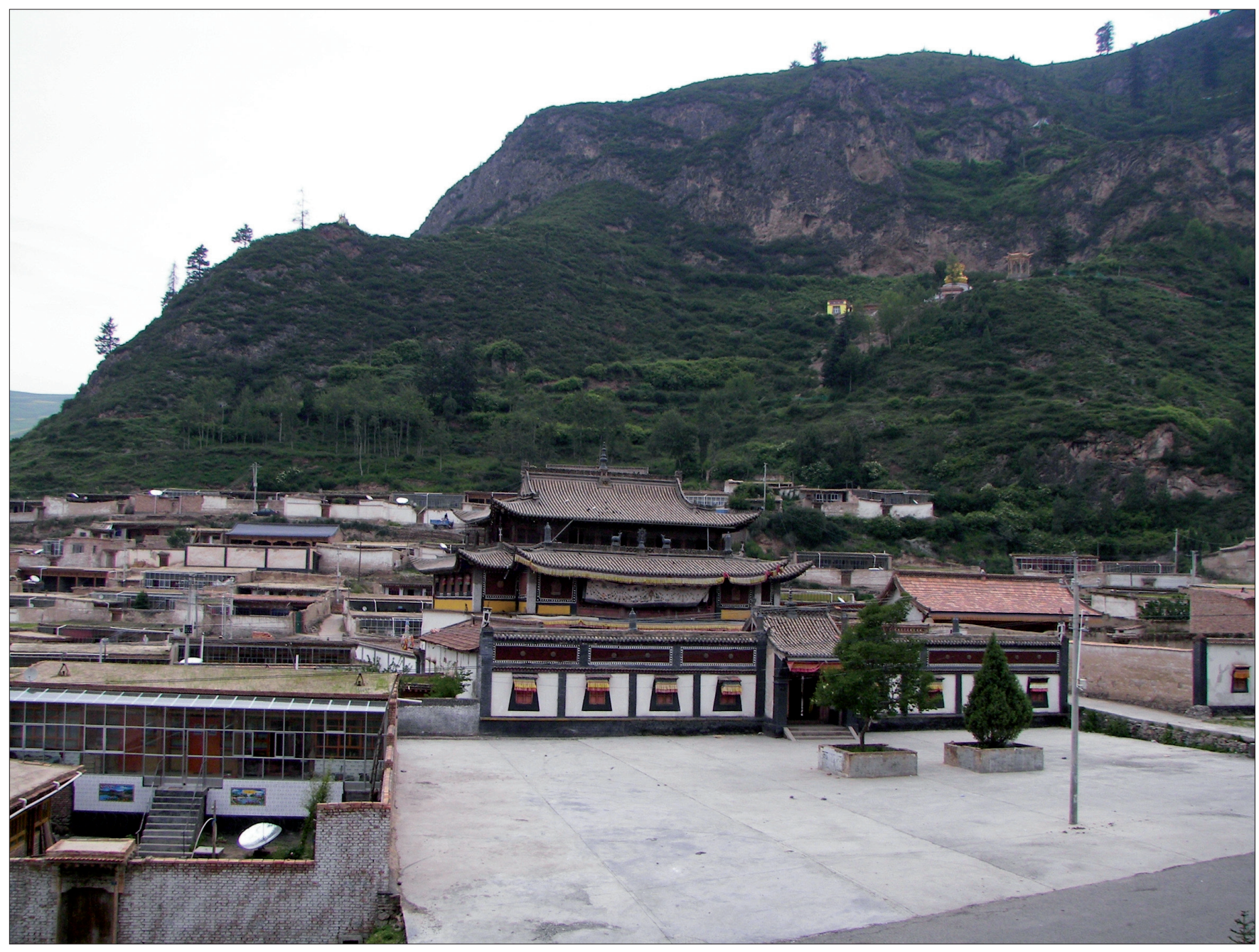

Obr. 9. Klášter Gönlunggönčhen (čínsky Jou-ning-s’ 佑寧寺) v provincii Čching-chaj - shromaždovací síń jedné z tantrických kolejí kláštera. Foto Jakub Hrubý.

\section{PŘEKLAD}

(Kapitola II, fol. 429-445)

Neviděl jsem žádný zápis o tom, kdo v nejstarších dobách panoval na území Kökenúrska. Ani není jisté, kdo na této pusté zemi ve starých dobách žil. Později, když kraj ovládli Tibetané z Pari ${ }^{34}$, se mezi nimi vyskytl blíže neznámý Phurccha-gampa Čhödordže(?) a ten žil na ostrůvku Cchoňingri v [jezeře Kőkenúr] a na dalších místech.

Po něm přišel vůdce tibetského kmene Ačhi(?), který vlastnil mnoho koní a byl zván Thitamarčän („Majitel 10000 červených koní"). $\mathrm{V}$ době, kdy on a jeho lid ovládali tento kraj, vyskytl se lama Langkarčän („Vlastník bílého vola“), putující na bílém volu a vypadající jako svatý muž. Ten žil v místech jako Cchoňing[ri] a ve skalní jeskyni Gönpodong, nacházející se na západním břehu jezera. Mnohé z těch skal připomínaly přirozeně vzniklé [podoby] hněvivých božstev a [tvary] obřadních předmětů.

34 Pari - oblast v povodí řeky Ta-tchung-che tekoucí na rozhraní Čching-chaje a Kan-su.
V té samé době zde žili Tibetané z Čone. ${ }^{35}$ Později do těchto míst táhl Lingdan-chutuchtu ${ }^{36}$, avšak cestou zemřel. Potom se mezi zde rozptýleně žijícími kmeny usadil na březích řeky Mačhu (Žlutá řeka) kmen Čacharů. ${ }^{37} \mathrm{~A}$ ti, poté co zabrali zemi a zmocnili se jejích pevností, začali obdělávat zdejší půdu. - Je-li tomu tak, pak se nezdá být jisté, že by [toto území] do té doby vủbec mělo nějakého velkého vládce. Potom [v oblasti Kökenúru] po dlouhou dobu žil se svými poddanými a pŕíbuzenstvem tümedský [vůdce],

35 Čone, též Čoni - okresní město v provincii Kan-su, dnešní středisko Tibetského autonomního kraje Känlho osídleného Tibetany. Více o nich J. F. Rock, Life Among the Lamas of Choni, The National Geographic Magazine 54 (1928), 569-616.

36 Lingdan, též Ligdan - 1592-1634, poslední chán z rodu Čingisova, s čestným titulem chutuchtu pro jeho horlivé šírení tibetského buddhismu mezi Mongoly.

37 Čachar - Čacharsko, rozsáhlé území táhnoucí se podél severní strany Č́nské zdi na východ až do dnešního Vnitřního Mongolska. Též název jeho obyvatel. 


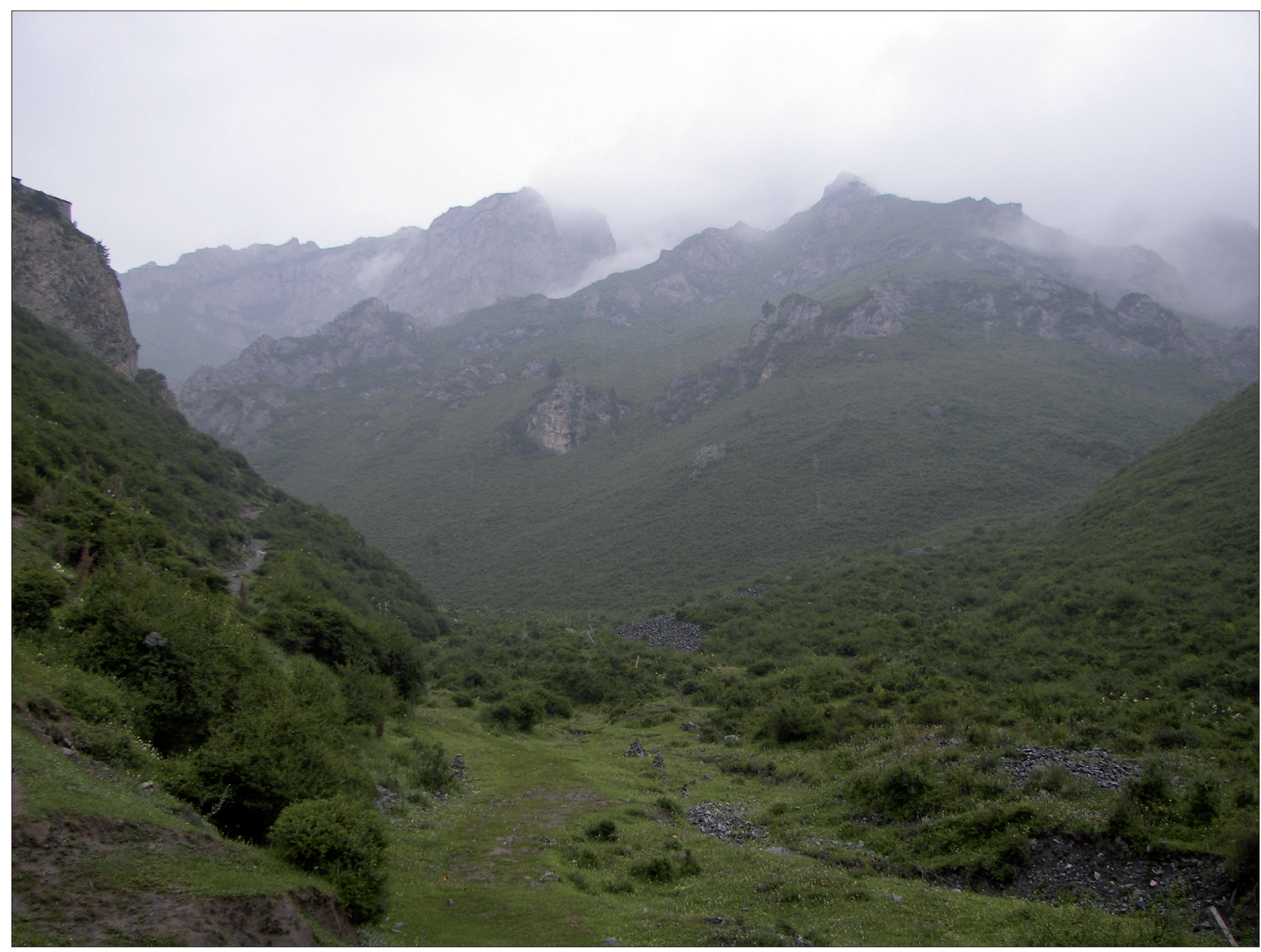

Obr. 10. Svahy posvátné hory Tugaan-ula za klášterem Gönlung cestou k jedné z klášterních pousteven (Tchien-men-s’ 天門寺). Foto Jakub Hrubý.

jménem (v čínském přepise) Chuo-luo-čch. ${ }^{38}$

Tehdy se neposkvrněné učení Žlutých čepic Gelugu druhého Buddhy Pána Lozangdagpy ${ }^{39}$ rozšírilo po Tibetu, ve Velkém $\mathrm{Tibetu}^{40}$ a $\mathrm{v}$ zemi mongolské. Mezi těmi, kdo v ně upřímně věřili, byli:

- Čtyři [kmeny] mongolských Öledư̊ ${ }^{41}$ na Severních pláních

38 Chuo-luo-čch'(?) - prasynovec vůdce tümedských Mongolů Altanchana (1507-1582). - Tümediané (novomongolsky Tümd) tvořili součást tzv. konfederace jižních Mongolů.

39 Lozangdagpa - známější jako Congkhapa (1357-1419), pochází z okresu Congkha v Amdu. Za studií v Centrálním Tibetu založil reformovanou školu Gelug, tzv. Žlutou sektu. Zde uctivě zván „druhým Buddhou“ (po prvním, jímž je Buddha Šákjamuni).

40 Velký Tibet - autor rozlišuje „Tibet“ (Bö), pod nímž rozumí území Centrálního Tibetu (Ücang) tvořené Předním Tibetem (Ü), Zadním Tibetem (Cang) a oblastí Ngari na nejzazším západě, a „Velký (nebo Větší) Tibet“" (Böčhen), pod nějž zahrnuje také Kham na východě a Amdo na severovýchodě.

41 Öled (staromongolsky Ögeled, novomongolsky Öld), též Ojrat - skupina čtyř jižních a západních Mongolů Chošúdů, Džúngarů, nahoře; Amdané z Pari a další ve Velkém Tibetu uprostřed. - Většina Monguorů v nížinách dole.

Pokud jde o ty, kteří [gelugpovské] učení nepřijali, ale hlásili se upř́mně k jiným tibetským náboženským školám, byli to: - Cangský král Karma Phüncchognamgjal a jeho syn Tänkjongwangpo ${ }^{42}$, kteří se dříve i později zbožně hlásili ke školám Karma a Dugpa. ${ }^{43}$

- Khamský král v Beri Dönjögjalpo ${ }^{44}$ se skláněl před učením

\section{Dörbetů a Torgúdů.}

42 Cangpa - tibetská dynastie (1565-1642), podporující školu Karma, byla v opozici vůči škole Gelug. Třetí její král byl zván Karma Phüncchognamgjal (1607-1621). Jeho nástupcem byl Karma Tänkjongwangpo (1621-1642), usmrcený Gušrichanovými vojáky.

43 Karma - subsekta školy Kagjü, založená Gampopovým (10791153) žákem Čhöndzingenphelem (1110-1193), známým též jako Düsumkhjenpa. - Dugpa - škola tibetského buddhismu založená Lingräpou Pämadordžem (1128-1183). Škola Dugpa dnes převládá v Bhútánu.

44 Kham - východní Tibet, tvořící oblast mezi Předním Tibetem a provincií Jün-nan 云南, zahrnovaná pod pojem „Velkého Tibetu“. 


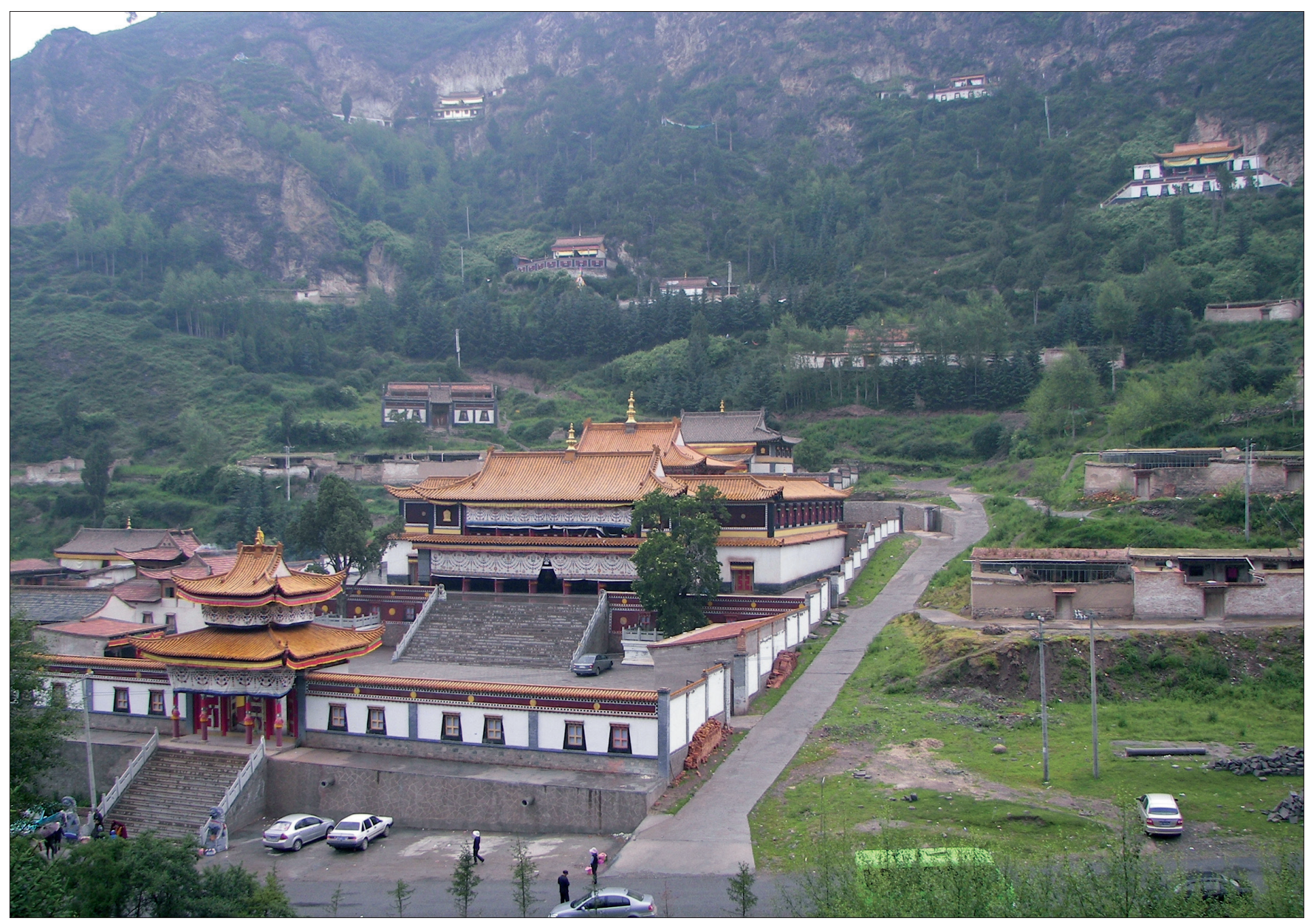

Obr. 11. Hlavní shromaždovací síň kláštera Gönlung a poustevny a rezidence převtělenců ve svazích hory Tugaan-ula. Foto Jakub Hrubý.

bönu. ${ }^{45}$ Pokud jde o krále Cchogthua v Chalše ${ }^{46}$, ten tvrdil, že vyznává buddhismus, ve skutečnosti však našel zalíbení $\mathrm{v}$ [učení] čínských bönistư ${ }^{47}$, to jest v taoismu.

- Pokud jde o tř́icátého sedmého ${ }^{48}$ vládce z královského potomstva Čingisova (16 velkých chánů a 21 menších chanů)

\footnotetext{
- Beri - město ležící na levém břehu řeky Ňagčhu (čínsky Ja-lung 鴉礱). - Na beriského krále Dönjögjalpa, též Dönjödordžeho, pronásledovatele místních gelugpovců, Gušrichan v roce 1639 zaútočil a v následujícím roce ho zajal.

45 Bön - bönismus, původní náboženství Tibetanů před přijetím buddhismu. V pozdějším vývoji byl bönismus doktrinálně i organizačně značně ovlivněn tibetským buddhismem. Viz Kolmaš 2009, 59.

46 Chalcha, Chalšsko - bývalé Vnější Mongolsko (dnešní Mongolská republika). - Cchogthu, též Čhogthu - chalšský „král“, který se svou armádou vtrhl do Kökenúrska.

47 Čínští bönisté - rozumí se taoisté (tao-žen 道人).

48 Třicet sedm vládců - představuje 16 (ve skutečnosti 17) velkých chánů (ze starotürkického „kagan“), po Čingischánovi (1206-1227) jako prvním, kteř́ od roku 1271 vládli jako mongolská dynastie Jüan na čínském císařském trůnu (1271-1368), a 21 menších chanů (z čínského „kuan“ 官), kteří se udrželi u moci na mongolských zemích po pádu Jüanů a útěku posledního chána Toghon Temüra (1333-1368) za čínské dynastie Ming (1368-1644).
}

Lingdana, není jasné, k jaké víře se hlásil.

Dále, lidé [v provincii] $\mathrm{U}^{49} \mathrm{v}$ Centrálním Tibetu se přidržují učení Staré školy [Ňingma], které hlásal Guru Čhöwang. ${ }^{50}$

I když čtyř̀i výše zmínění vládcové se každý hlásili k nestejné víre, byli všichni zajedno ve velkém nesouhlasu s gelugpovci. Je to jako v prísloví: „Jelen je živ trávou a listím, sup kamínky, plaz vzduchem a sněžný medvěd ovocnými plody“ - každý požírá různou stravu, ale všichni žerou maso a všichni se shodují v odporu k pachu pižma, které je obecně považováno za libě vonící a za nejlepší medikament.

Avšak později, když do těchto míst přišel džúngarský vládce Gušri, jak bude vyloženo níže, všechny odpůrce učení Žluté školy potřel a čisté mravy školy Gedän ${ }^{51}$ nechal zářit jako mocné slunce.

Tolik [v kostce] obecné vylíčení [osudů tohoto území]. Po-

$49 \ddot{U}$ - tzv. Přední Tibet s centrem ve Lhase, východní ćást Centrálního Tibetu (Ücang) přiléhající ke Khamu.

50 Guru Čhöwang, též Čhökjiwangčhug - 1212-1278, který hrál důležitou úlohu v pozdějším rozvoji Staré školy (Ňingma) tibetského buddhismu jako nálezce tzv. termových („ukrytých“) textů.

51 Gedän - doslova „Ctnostná“, je alternativní název pro Congkhapovu školu Gelug. Gelugpovci jsou u autora často zaměňováni Gedänpovci. 
kud jde o konkrétní [historické] události, podám - dodatkem $\mathrm{k}$ [předchozímu stručnému] výkladu několika př́běhů jednotlivých vládců - obecnější dějiny pro informaci mnohých pozdějších generací, kterak $\mathrm{v}$ oněch dobách za sebou následovali velcí lamové a vládci Číny, Tibetu a Horu ${ }^{52}$, jakož i k jakým dobrým či neblahým událostem kdy docházelo.

\section{HISTORICKÝ VÝVOJ CHRONOLOGICKY (1570-1786)}

\section{0}

V [mužském] roce Železa a Koně desátého šedesátiletého cyklu [1570] se narodil pančhenlama Lozang Čhökjigjalcchän $[1570-1662] .^{53}$

1612

V [mužském] roce Vody a Myši [1612] Cangpa Karma Phüncchognamgjal $^{54}$ [1607-1621] podrobil své moci území Cangu a byl prohlášen prvním králem Horního Cangu.

1617

V [ženském] roce Ohně a Hada [1617] se narodil velevzácný lama Pátý dalajlama. ${ }^{55}$

1618

V [mužském] roce Země a Koně [1618] se cangský král zmocnil také Předního Tibetu [Ü] a pronásledoval množství stovek mnichů a laiků na horách za Lhasou a Däpungem a [dokonce] měnil gelugpovské nauky. Mniši z Däpungu a Sery ${ }^{56}$ se rozutekli a když dorazili do Taglungu a Phumda, ${ }^{57}$ dostalo se jim [od tamních lidí] vřelého přijetí. Říká se, že později byly Taglungským věnovány použité čajové lístečky, které byly během svátku Mönlam ve Lhase používány k hoštění „čajem pro mnohé“. 58

52 Hor - obecný název pro Mongoly žijící na Tibetské náhorní plošině od Ngari na západě až po Východní Turkestán a vlastní Mongolsko (Sogjul) na severu.

53 Pančhenlama, též Pančhen-rinpočhe nebo Pančhen-erdeni - titul druhého nejvýše postaveného duchovního školy Gelug, sídlícího v klášteře Tašilhünpo, a datující se od roku 1385. - Lozang Čhökjigjalcchän (1570-1662) byl podle jednoho číslování prvním, podle jiného (dnes převládajícího) čtvrtým pančhenlamou.

\section{Viz poznámku 42.}

55 Pátý dalajlama - Ngawang Lozanggjamccho (1617-1682), doma zvaný Ngapa-čhenpo („Velký Pátý“), sjednotil s pomocí Gušrichana politicky Tibet, sídlo dalajlamů přenesl z Däpungu do Lhasy, kde začal s výstavbou paláce Potaly. - Dalajlama - mongolsko-tibetský titul s významem „oceánový lama“, udělený poprvé v roce 1578 mongolským vládcem Altanchanem (1507-1582) tehdejšímu třetímu nejvyššímu představenému školy Gelug Sönamgjamcchovi (1543-1588).

56 Däpung - velkoklášter západně od Lhasy (založen 1416), jehož první čtyři opati byli původně nejvyššími představenými školy Gelug. - Sera - nacházející se severně od Lhasy, po Däpungu druhý největší gelugpovský klášter v Tibetu, založený v roce 1419.

57 Taglung - okres severně od Lhasy na horním toku řeky Kjičhu. Tamní kagjüpovský klášter byl založen v roce 1180. - Phumdo - město v blízkosti Taglungu při jižním břehu řeky Kjičhu.

58 Čaj pro mnohé, tibetsky mangdža - obyčej poskytování čajo-
Zhruba v téže době byl u Tašilhünpa stavěn nový velký klášter pro karmapovce a ňingmapovce. ${ }^{59}$ Když se na hoře za [tímto] novým klášterem stavěla vysoká věž, mnozí posměváčci jí dali jméno Tašizilnön, ${ }^{60}$ což mělo být zlým znamením. Ř́íká se, že [cangský král] také v Předním Tibetu vydržoval [kláštery] Seri(?) v Kjišö ${ }^{61}$ a karmapovský a ňingmapovský Thubčhenling(?). V těch dobách si gelugpovští mniši dělali klobouky se žlutou vlněnou podšívkou uvnitř a červenou nášivkou zvenčí a podle okolností je [na veřejnosti] nosili bud'to vnitřkem ven, nebo venkem dovnitř. Ještě dnes mezi svými stoupenci tento Garu-locawovský klobouk nosí. ${ }^{62}$

1621

V [ženském] roce Železa a Ptáka [1621] přitáhli z dolních částí [Kőkenúrska] synové vládce Chuo-luo-čch’a Guru chungtajdž a lhabcün („ctihodnýc) Lozang Tändzingjamccho s mongolskými vojsky a spojíce síly se spř́telenými vojsky kjišöských vrhli se $\mathrm{v}$ kjišöském Kjangthanggangu ${ }^{63}$ jako blesk na cangská vojska a Cangské porazili. Následně pak osvobodili Lhasu a jiná místa, dříve ztracená, a změněné [náboženské] nauky obnovili do původní podoby.

A dále, podle platných zákonů známých jako „Šest velkých mongolských kmenü“"64 se [mezi Mongoly] netrpěly žádné nedobré praktiky, jako $\mathrm{v}$ době války vnitřní nesváry mezi vlastními soukmenovci či zabíjení zajatců jako ovcí. Zbraně bylo možno používat pouze v dobách války. Avšak za časů špatných vládců Lingdanchana a Cchogthua se tyto obyčeje běžně rozšiřily.

1628

Tak v [mužském] roce Země a Draka jedenáctého šedesátile-

vých lístků mnichům coby almužnu o svátku Mönlam-čhenpo („Velké modlení), náboženské slavnosti ve Lhase v období tibetského Nového roku. Tradici zavedl Congkhapa v roce 1409.

59 Karmapa - karmapovec, prŕslušník školy Karmakagjü z 12. století - Ňingmapa - ňingmapovec, př́slušník předreformní školy tibetského buddhismu Ňingma („Stará škola“), spojované s činností indických mistrů Šántarakšity, Vimalamitry a Padmasambhavy v 8. století. Viz Kolmaš 2009, 111 a 150.

60 Tašizilnön - doslova „Utláčeč Taši[lhünpa]", karmapovský klášter v Žikace s výhledem na sousední gelugpovský klášter Tašilhünpo. „Kvádry potřebné na stavbu kláštera byly získávány z hory nad Tašilhünpem a dělníci je schválně nechali dopadat na př́bytky gelugpovských mnichů, mnohé z nichž tímto způsobem zabili." Viz Žagabpa 2000 [2008], 99.

61 Kjišö - starý název území v okolí Lhasy.

62 Garu-locawa - gelugpovský mnich z kláštera Gönlunggönčhen v Amdu v předstíraných službách cangského krále. On, anebo jiný mnich Semňi(?), byl vyslán do Džúngarska požádat o pomoc pro gelugpovce utiskované cangským králem.

63 Kjangthanggang - místo mezi lhaskou Potalou a klášterem Däpung na severozápadní straně lhaského kopce Čagpori.

64 Šest velkých mongolských kmenů, též „Šest tümenů [desetitisícníků] “ - Gušrichanův syn Dajanchan, chošúdský král Tibetu v letech 1655-1668, si rozdělil poddané mongolské kmeny na „Pravé korouhve“ (Barúngar) a „Levé korouhve“ (Džúngar). Do „Pravých korouhvi“ patřili Čachaři, Urianchajci (Tuvinci) a Chalšané, do „Levých korouhví pak Ordosané, Tümedi a Jungsijebüové. 


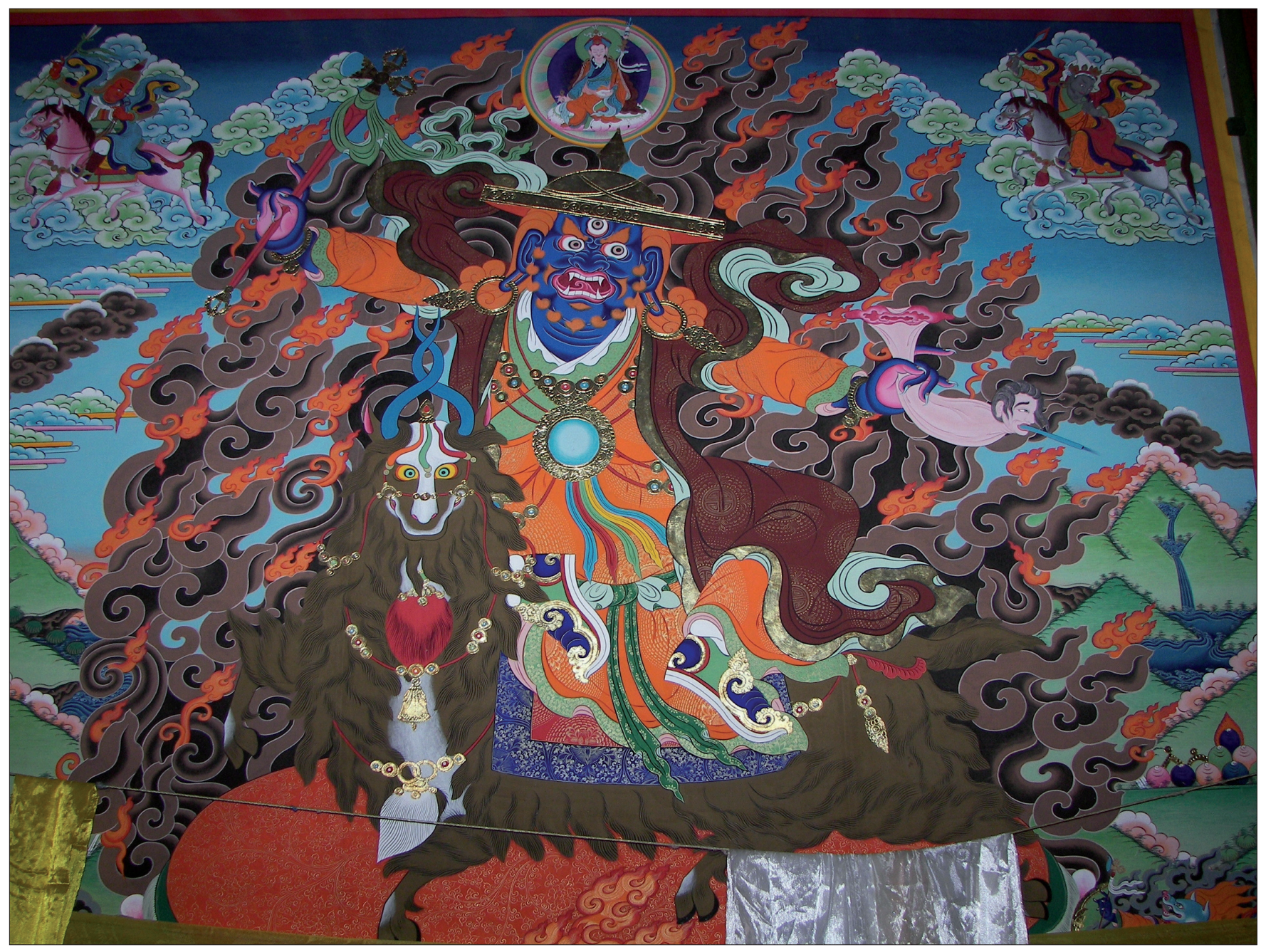

Obr. 12. Ochranné božstvo (damčän) Garwänagpo - nástěnná malba v hlavní síni lékařské koleje kláštera Čhakhjung (Ťia-čchiung-ča-s’ 甲窮札寺).

Foto Jakub Hrubý.

tého cyklu [1628] Lingdanchan porušil zákony Čingischánova vlastního kmene, rozpoutal občanskou válku mezi Čachary, pobil mnoho lidí a uzavřel přátelství s těmi, kdo nahoře [na severu] pronásledovali gelugpovce. Cestou do [Kőkenúrska] porazil několik tümedských a ordoských kmenů. ${ }^{65}$

1634

V [mužském] roce Dřeva a Psa [1634], když [Lingdanchan] dorazil k Šara-talu na tibetském území, ${ }^{66}$ ho [božstva] Čhögjal-namsum ${ }^{67}$ poslala do "pátého stavu“ [to jest usmrtila]. ${ }^{68}$ $\mathrm{V}$ dobách, kdy knížata mezi sebou bojovala, se mnoho ča-

65 Ordos - pouštní oblast ve velkém ohbí Žluté řeky (Che-tchao 河套) v severní části čínské provincie Šen-si 陝西. Ordosané jsou př́slušníky mongolských národů $\mathrm{v}$ dnešní Čínské lidové republice.

66 Šara-tal - „Žlutá planina“v Tangutsku, kde Lingdanchan v bojích o Kőkenúrsko v roce 1634 skonal.

67 Čhögjal-namsum - tř̀ ochranná božstva (čhökjongové) školy Gelug.

68 pátý stav - tibetsky ngapa. Podle bráhmanského učení je pět životních stavů: 1) život $\mathrm{v}$ čistotě, 2) život světského hospodáře, 3 ) přebývání v pralese, 4) tuláctví, 5) smrt. charských utečenců uchýlilo do Chalšska. V tom roce Dřeva a Psa [1634], kdy zlý vládce Cchogthu rozpoutal občanskou válku a oddával se svým zvrácenostem, ho mnozí lidé z Chalchy od sebe vyhnali. On se pak uchýlil do Kőkenúrska, kde si podmanil tümedského Chuo-luo-čch’a a jeho lid. Byl pak zván Kőkenúrským králem Cchogthuem.

A tak, když král Horního Cangu zle pronásledoval gelugpovce, zabíjel král z dolního Beri mnoho mnichů a úředníků vyznávajících buddhismus a mnohé $\mathrm{z}$ nich vsadil do vězení. Mnozí gelugpovští lamové a mniši byli Cchogthuchanem budto zabiti, nebo uvězněni. Vinou počínání těchto dvou [králů], jako bylo například zboření zlatého mostu, po kterém množství věrících přecházelo do Předního a Zadního Tibetu, spělo Congkhapovo učení k úpadku.

Tehdy odešel do Tibetu také jeden tibetský úředník Sönamčhönphel a dva učení mniši z amdoského kláštera Gönlunggönčhenu - Garu-locawa, přezdívaný Načhen („Nosatý“), a Semňi(?), přezdívaný Khačhe („Velkohubý“) ${ }^{69}$ Ač všichni tři

69 Sönamčhönphel - první regent (desi) jmenovaný Gušrichanem v roce 1642. Zemřel v roce 1658. - Garu-locawa - viz poznámku 62. 


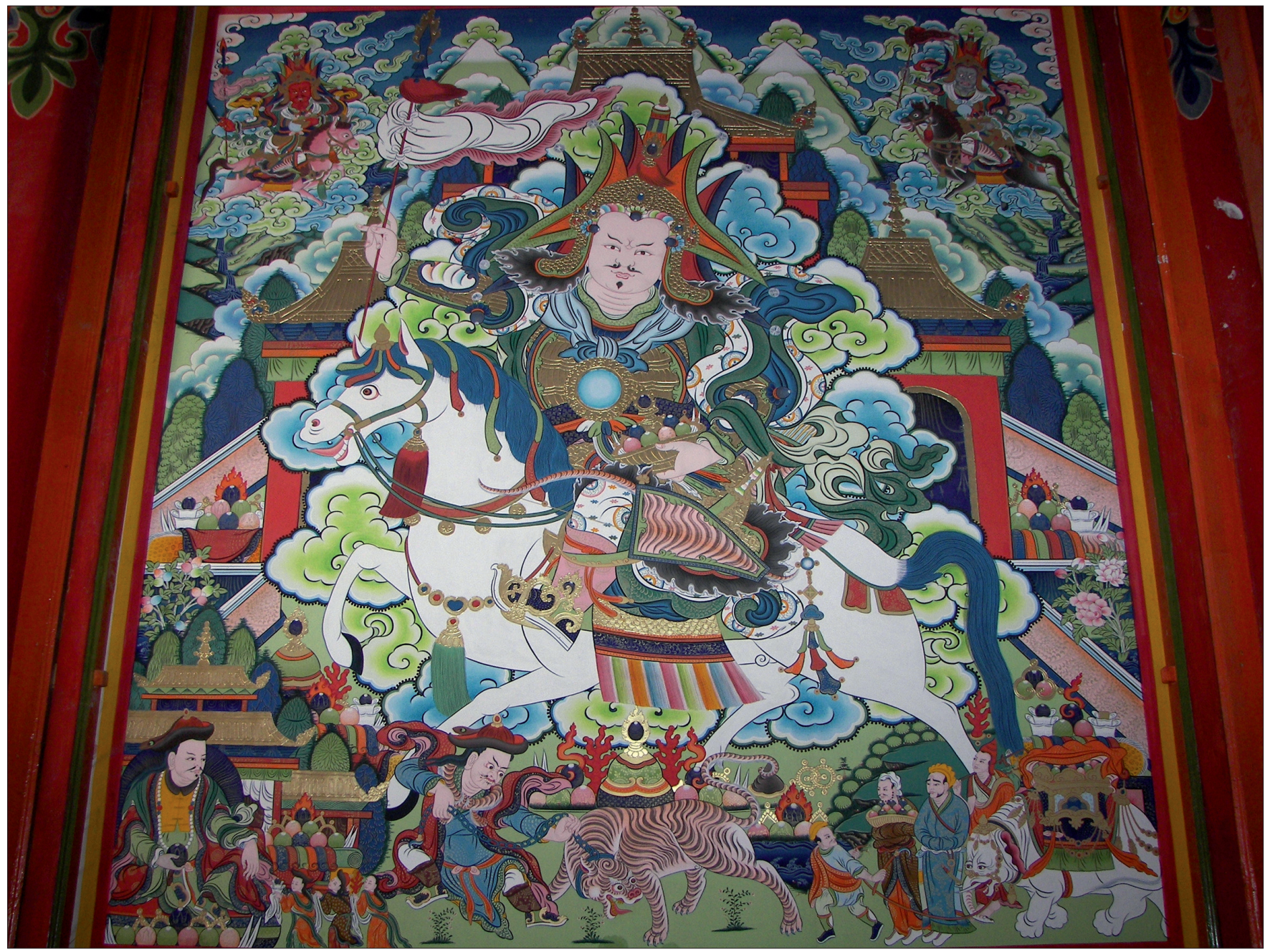

Obr. 13. Horské božstvo Amňe Čhakhjung uctívané jako ochránce kraje na horním toku Žluté řeky - nástěnná malba v hlavní síni lékařské koleje kláštera Čhakhjung (Ťia-čchiung-ča-s’甲窮札寺). Foto Jakub Hrubý.

byli stoupenci školy Gelug, byli bezmocně zařazeni do družiny cangského krále. Tehdy se tito [tři] dohodli s dobrodincem kláštera Gandän v Kjišö a s guvernérem okresu Tagcedzong Cchokjedordžem a požádali lamoského čhökjonga („věštce“) o provedení věštby. ${ }^{70}$ [Dostalo se jim předpovědi]: „Vůdce ze severu, opásaný šerpou v podobě hada, dokáže nepř́itele porazit." Ponechavše si tuto věštbu v tajnosti, vyslali do oblasti Džúngarska Semňiho nebo Garu-locawu.

Přišed do vlastní země [Amda], ujal se velení menšího oddílu spřátelených vojáků z Pari a vyrazil s nimi do Džúngarska.

- Gönlunggönčhen - gelugpovský klášter v Amdu, založený v roce 1604. - Načhen („Nosatý“) a Khačhe („Velkohubý“) jsou přezdívky dotyčných mnichů.

70 Gandän - jeden ze tř́i gelugpovských velkoklášterů východoseverovýchodně od Lhasy, založený Congkhapou v roce 1409. Ten tam má také svůj hrob. - Cchokjedordže - guvernér okresu Tagce severovýchodně od Lhasy na pravém břehu řeky Kjičhu, otec tagceského depy Lhagjalrabtäna (viz poznámku 138). - Lamo - malý klášter severovýchodně od Gandänu, kde měl své sídlo věštec-orákul (čhökjong).
Králi a úředníkům [tam] oznámil, že cangský král a ostatní chtějí nyní zničit Gedänpu a Žlutou školu velice nenávidí. A když byl vylíčil alarmující situaci nepřítele, vrátil se zpět do Cangu.

Když se poté král a úřednictvo sešli, aby rozhodli, kdo by se měl do Předního a Zadního Tibetu vydat, jistý člověk jménem Gušrichan učinil přísahu, řka: „Já se do Předního Tibetu vypravím!“

[Tento Gušrichan] patřil k rodu chošúdských Galgasů․․ kteři byli původně jedním ze čtyř öledských kmenů. Velký vladař Ha-niì nojan Hong-gwar(?) a jeho mladší královna A-hải chatun měli pět synů, známých jako „pět nadaných a odvážných tygrü“. Třetí z nich jménem Tho-ri-pe’ui-hu(?) se narodil v [mužském] roce Vody a Koně [1582]. Když mu bylo třináct let, táhl $s$ vojskem a porazil čtyřicetitisícovou armádu mus-

71 Galgas - královský rod údajných potomků Chasara, Čingischánova bratra. Gušrichan byl devatenáctým potomkem Chasarovým a Galgas bylo pravděpodobně jeho rodové jméno. Galgasové vládli Chošúdům. 


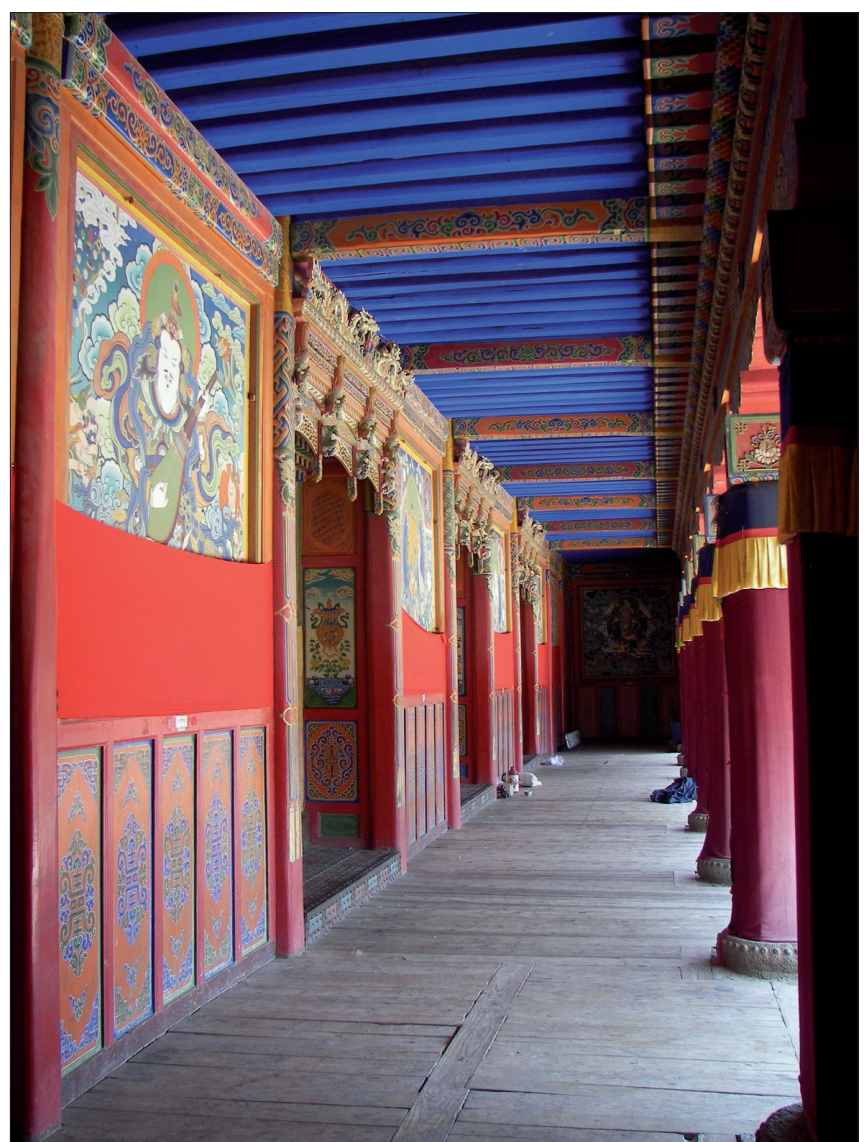

Obr. 14. Vestibul hlavní síně lékařské koleje kláštera Čhakhjung (Ťia-čchiung-ča-s’') s nástěnnými malbami čtyř králů ochránců světových stran. Foto Jakub Hrubý.

limských Gokarů („Bělohlavých“), ${ }^{72} \mathrm{v}$ důsledku čehož se jeho pověst hrdiny rozšírila a jeho moc vzrostla.

Dále pak, když měl dvacet pět let, došlo $\mathrm{k}$ nesrovnalostem mezi Öledy a Chalšany a vypukla [mezi nimi] velká občanská válka. A právě tehdy se tu objevil [Gušri] a svou dovedností a dobrými slovy dosáhl [mezi stranami] usmíření. Velký chalšský chán mu prredal [úřední] pečet' a titul ta'i-gu'u-šri. ${ }^{73}$ Tím se jeho hrdinství a dovednosti staly proslulými.

1635

V [ženském] roce Dřeva a Vepře [1635] vyslal Cchogthu svého syna Arsalang tajdže $e^{74}$ s deseti tisíci vojáky do Předního a Zadního Tibetu, aby pobil vysoké lamy školy Gedän a jejich kláštery a meditační místa rozprášil.

Ř́ká se, že když [Arsalang] dorazil k hornímu toku řeky

72 Gokar - „Bělohlav“, pojmenování muslimů podle bílé barvy jejich čepiček.

73 Ta'i-gu’u-šri-odpovídá čínskému ta-kuo-š’大國師, ,velký učitel ř́še“. Může souviset se jménem „Gušri“. - U jmen Hong-gwar, A-ha’i, Tho-ri-pe’ui-hu a titulu ta'i-gu'u-šri se jedná o tibetský přepis mongolských jmen.

74 tajdž - mongolský titul (staromongolsky tajidži, novomongolsky tajž), „šlechtic, aristokrat“, odvozený z čínkého tchaj-c’太子, „princ“.
Dičhu, ${ }^{75}$ setkal se s ním Gušri s několika svými úředníky, přicházející z Džúngarska jakoby na pout', ale [ve skutečnosti], aby zvěděli, zda zprávy někdejšího posla jsou pravdivé či nikoli. Po setkání s Arsalangem pokračoval tento s nimi, nebot mu Gušri předložil mnoho důkazů [o tom], proč je nepatřičné působit učení Žluté sekty škody. [Arsalang] si to vzal k srdci a pokračovali [spolu] do Tibetu. V prřśśtím roce [1636] se prý Gušri stejnou cestou vrátil do své země.

Když Arsalang se svými vojáky dorazil do Tibetu, nedbal slov svého otce a rozděliv vojsko do tř́ skupin - střední, pravé a levé - vtrhl k Jamdogu, ${ }^{76}$ kde svedl velkou bitvu s vojskem Cangských. Ale pro šírící se falešné zvěsti o silné tibetské armádě se mongolská vojska stáhla do Kjišö.

1636

V prvním měsíci [mužského] roku Ohně a Myši [1636] se Arsalang a ostatní setkali s Pátým dalajlamou. Klášterům a meditačním místům gedänpovců nepůsobil žádné škody, naopak vůči nim projevoval nábožnou úctu. Když se potom velké tibetské vojsko zformované cangským králem blížilo $\mathrm{k}$ [jezeru] Namccho ${ }^{77}$ na severu, přesunula se také mongolská armáda k severu a chystala se k boji. Protože však Cangové tehdy použili magickou sílu starých zaklínadel, Arsalang se pomátl na rozumu a vrhl se jako šílenec mezi své vojsko. Mongolští vojáci pak stř̌et odložili a tibetské vojsko se rozešlo. Tehdy byl rozšíren názor rabdžampy ze školy Červených čepic $^{78}$ a ostatních, kteří byli na straně cangského krále, že Cchogthu a Cangští mají stejný cíl, totiž že podporují karmapovce, dugpovce a ňingmapovce a k ostatním náboženským školám v Tibetu zaujímají stejný postoj, ale že [ve skutečnosti] chtějí jméno gelugpovců vyhladit. Je to jak se praví v přísloví: „Kůň nepoběží tam, kam si to jezdec přeje.“

Rabdžampa z Červených čepic a jeho úředníci, kteří se dostavili do Cchogthuova vojska, vyslali do Kőkenúrska posla s [tímto vzkazem]: „Arsalang, neposlušen slov svého otce krále, gelugpovcům škody nezpůsobuje, naopak projevuje vůči nim nábožnou úctu a s cangským králem bojuje. Tak si počíná." Cchogthu odpověděl: „Zabte ho [všemi] zpưsoby!“ Podle toho se [Arsalang] ztratil jako když [mizí] mráček uprostřed jasné oblohy, a mongolská vojska se vrátila [do Kökenúrska]. V tom roce [1636] Gušri se spojeneckými vojsky džúngarského Bátur-tajdže $e^{79}$ přišli na toto území. Cestou procházeli [krajinou] I-li a Tarimem, ${ }^{80}$ a na rozhraní podzimu a zimy překro-

75 Dičhu - tibetské jméno horního toku řeky Jang-c'-tiang, v těch místech zvané Tchung-tchien-che 通天河.

76 Jamdog - jezero Jamdogccho v jižní části Centrálního Tibetu na rozmezí Předního a Zadního Tibetu.

77 Namccho - „Nebeské jezero“, mongolsky zvané Tengrinúr (severně od Lhasy).

78 rabdžampa - akademický titul „doktor bohosloví, zde mnicha předcongkhapovské sekty „Červených čepic“ (Žamar).

79 Bátur-tajdž, též Bátur-chungtajdž - vládce Džúngarska. Titul chungtajdž odvozen z čínského chuang-tchaj-c’ 皇太子, „dědic-nástupce“.

80 I-li 伊犁 - hlavní sídlo Džúngarů v Čínském Turkestánu (dnešním Sin-tiangu 新疆). - Tarim - územní proláklina v Č́nském Turkestánu. 


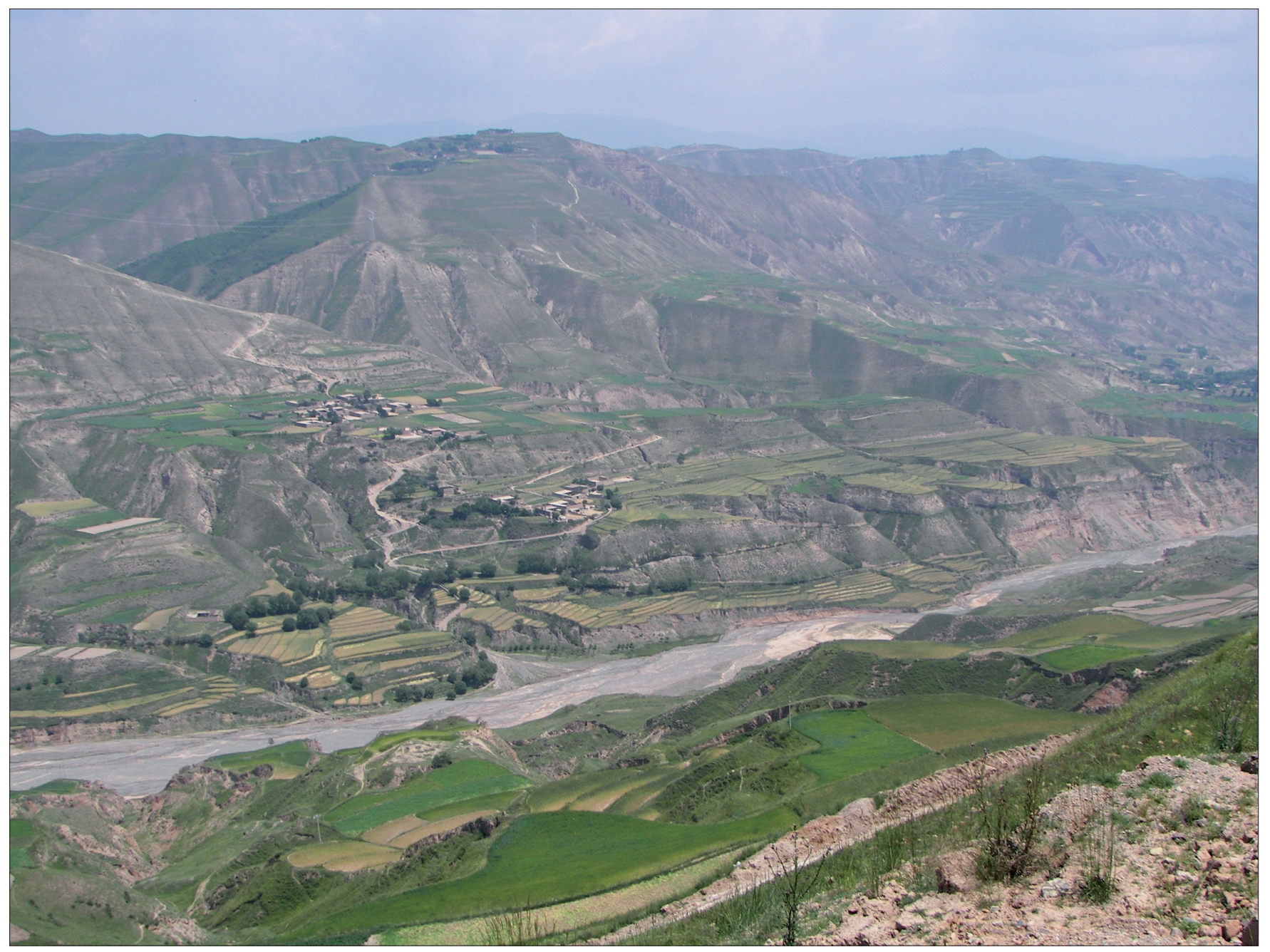

Obr. 15. Pole s dozrávajícím ječmenem v údolí jednoho z př́itoků Žluté řeky pod klášterem Čhakhjung. Foto Jakub Hrubý.

čili řeku Has-tag(?) a velká mokřiska Cchädamu. ${ }^{81}$ Dorazivše k Bulungiru ${ }^{82}$ na hranicích Kőkenúrska, kde si vojáci a koně odpočinuli. Živi na množství divokých antilop, dali hoře jméno Gwan-jam-thu(?).

1637

Na Novoroční den prvního měsíce [ženského] roku Ohně a Vola [1637] dorazilo desetitisícové [Gušriho] vojsko do horního Kökenúrska a svedlo velkou bitvu s třicetitisícovým vojskem Cchogthuovým. Protože oba [tamní] horské srázy zrudly krví, říká se jim dnes Velký a Malý Ulán-chošú („Rudé předhoříi").

[Gušriho] syn Dajanchan tajdžz a ostatní pronásledovali s vojskem zbytky Cchogthuova vojska přes zamrzlou [řeku] Har-gel(?) a porazili je. Někteří vojáci zamírili až do údo-

81 Cchädam, staromongolsky Čajidam, novomongolsky Cajdam, čínsky Čchaj-ta-mu 柴达木 - „Slané bahnisko“, proláklina v severozápadní části Čching-chaje.

82 Bulungir - lokalita na západním břehu řeky Pu-lung-šuej 布隆水v Čching-chaji.

83 Dajanchan - 1655-1668, Gušrichanův syn a nástupce. lí na východní straně [řeky], které obsadili. Dnes se [tomu místu] ř́ká Ša-hal(?). Pokud jde o vůdce Cchogthua, ten byl lapen ve svištově díře a [tento] nepřítel učení gedänpovců byl poražen. Kdyby to tehdy bylo jako $\mathrm{v}$ Indii, pokládalo by se za patřičné bušit do triumfálního bubnu a vztyčovat praporce vítězství nad neprrítelem.

1638

Potom v [mužském] roce Země a Tygra [1638] a v [ženském] roce Země a Zajíce [1639] postupně také všichni [lidé] Gušrichanova kmene $\mathrm{v}$ Džúngarsku přicházeli do Kőkenúrska. Poté [Gušrichan] udělil svému bojovému druhu tajdžovi titul Bátur-chungtajdž, [poctil ho] bezpočtem darů a vlastní dceru Amintáru(?) mu dal za ženu a poslal je zpět do své země [Džúngarska]. V tom roce, kdy přišel [Gušrichan] do Předního Tibetu, vyznamenal ho Pátý dalajlama názvem tändzinčhögjal, „zbožný král vyznavač Učení“.

1639

Navíc, na počátku [ženského] roku Země a Zajíce [1639] vládce $\mathrm{z}$ Beri poslal cangskému králi poselství [tohoto obsahu:] „Spojme se $\mathrm{v}$ přátelství! Jelikož ta měděná socha 
Džowo-rinpočheho ${ }^{84}$ byla příčinou války, vhod’me ji do vody! Na troskách tří klášterů Sery, Däpungu a Gandänu vystavme po čhörtenu ${ }^{85}$, a potom at' se každý $\mathrm{z}$ nás drží toho [učení], které shledá výhodnějším - buddhismu, nebo bönismu. “ Někteří lidé se [beriskému králi] vysmívali, říkajíce o něm, že je zcela zkažený.

V té době svolal cangský král vojsko [všech] třinácti myriarchii $^{86}$ Tibetu. [Gušrichan] se s ním neutkal a vrátil se nazpět do Kőkenúrska. Tehdy [také Dajanchanův] syn Ratna-tajdžz7 a jiní svolali všechny poddané tibetské vojáky z Amda, [známé] svou sílou a vojenským hrdinstvím. Velkoklášteru Gönlungčhamlingu ${ }^{88} \mathrm{v}$ centru Pari byl darován velký klášterní majetek [na území] od Lab-ccho-khra-mangu(?) až po jezero $\mathrm{Te}(?)$.

Potom v pátém měsíci [ženského] roku Země a Zajíce [1639] Gušri-gegénchan ${ }^{89}$ vyrazil osobně s velkou odstrašující mongolskou armádou, která [se hnala] jako rudo-černá vichřice. Když dorazila na území malého krále z Beri, který zničil téměř všechno učení Buddhovo, zmocnil se [Gušri-gegénchan] svou silou a dovedností většiny Khamu.

1640

Dvacátého pátého dne jedenáctého měsíce [mužského] roku Železa a Draka [1640] byl král z Beri zajat a uvězněn. Poté mnozí [beriským] králem věznění lamové a laici, sakjapovci, gelugpovci, karmapovci, dugpovci, digungpovci a taglungpovci ${ }^{90}$ byli [ $z$ vězení] propuštěni. A tak se kraj naplnil slovy radostných písní. Následně všechna území krále ze Sadamu na území Džangu ${ }^{91}$ se ocitla pod [Gušri-gegénchanovou] vládou.

84 Džowo-rinpočhe - slavná Buddhova socha, představující ho ve dvanácti letech, kterou přinesla do Tibetu princezna Wen-čcheng 文成věnem tibetskému králi Songcängampovi (605-650).

85 čhörten - „schrána obětních předmětů“, obecně schrána tělesných ostatků, zejména význačných lamů-převtělenců. Kultovní stavba, zpravidla zděná, v půdorysu čtvercová, přecházející pyramidovitě v kupoli a zakončená emblémy slunce a měsíce. Viz Kolmaš 2009, 71.

86 myriarchie - tibetsky thikor-čusum („třináct okruhů po deseti tisíci“), územně-administrativní uspořádání Předního (1-6) a Zadního (7-13) Tibetu.

87 Ratna-tajdž - „Drahocenný tajdž, Dajanchanův syn a nástupce Dalajchan (1668-1701), Gušrichanův vnuk.

88 Gönlungčhamling, též Gönlunggönpa - klášter v Pari založený $\mathrm{v}$ roce 1604 .

89 gegénchan - gegén, jedna z nejvyšších hodností v mongolské buddhistické církvi.

90 Sakjapovci - př́islušníci školy Sakja, založené v roce 1073. Gelugpovci - viz poznámku 2. - Karmapovci - viz pozn. 59. - Dugpovci - viz poznámku 43. - Digungpovci - prŕslušníci subsekty školy Kagjü, založené Džigtengönpem (narozen 1143). - Taglungpovci sekta odvozená z Digungpy, založená Tašipalem (1142-1210). Viz poznámku 57.

91 Džang - území mezi východním Tibetem a Jün-nanem. Za Tchangů zde byla říše Nan-čao 南詔, za Suejů se území ŕíkalo Ta-li-kuo 大理國. - Sadam - lokalita v severozápadním Jün-nanu zvaná ćínsky Li-tiang 麗江.
1641

V [ženském] roce Železa a Hada [1641] opět vedl [Gušrichan] velké vojsko a přes Přední Tibet dorazil do Cangu. Tam se velká armáda vedená zbrklým mladším synem dřivějšího cangského krále ${ }^{92}$ utkala v boji s mongolským vojskem, byla však jako ptáček pronásledovaný jestřábem zneškodněna.

1642

Když bylo Gušrimu šedesát jedna let, osmého dne prvního měsíce [mužského] roku Vody a Koně [1642], získal třináct tvrzí (dzongů) v Horním Cangu. Cangský král byl zajat a zašit do kůže. Také se říká, že byl usmrcen úředníkem Sönamčhönphelem. ${ }^{93}$

Potom se i Kongpo, území mezi Khamem a Tibetem, kde [lidé] věřili karmapovcům a velice nenáviděli gedänpovce, dostalo pod [Gušrichanovu] moc. [Ten rovněž] poskytl nové nadace mnišským školám ve třinácti známých klášterech (lingzích). Učiniv tak, tím, že totálně zvítězil nad všemi nepřátelskými územími, ovládl svou mocí všechno, co je známé jako Čholkhasum („Tři tibetské provincie“).94

Patnáctého dne třetího měsíce toho roku [1642] usedl [Gušri] na vysoký trůn „tibetského krále“ (bögjal) a někteří králové Indie, Nepálu a [na západě ležícího] Ngari ho podarovali hodnotnými dary.

Stručně řečeno, tak velice rozšíril své panství a jméno tändzinčhögjal Gušri-gegénchan zaznívalo na všech stranách. Jeho početná, hrdinská, obratná vojska se jako vše zatemňující černý deštový mrak podobala velké akšauhiní armádě Indie. ${ }^{95}$ Pohybovala se jako černá vichřice a vyrážela neustále [do bojů] jako hlučné červené blýskání. [Jejich] víra vystřelovala blesky zastrašujících, nezadržitelných a všespalujících zbraní a plod skutků minulých temných zvráceností nyní dozrál. Rozliční nepřátelé se zvrácenými myslemi, krutí a drsní jako skaliska, vzpírající se gelugpovskému učení Pána druhého Buddhy [Congkhapy] a jeho svatých následovatelů a dobrodinců, byli nakonec slavnostně poraženi. Díky působení jemného deštíku „dvojice zákonů“ thimzung, ${ }^{96}$ který zavlažuje všechna přání, rozkvetlo v Tibetu za panování duchovní a světské moci jako na jarním jezeře všechno ovoce i úroda na horách, pláních a v lesích. Jako slunce a měsíc zdobí nebesa, tak se i na zemi po vší Číně, Tibetu a Mongolsku rozléhají zvučné tóny vítězného bubnu dobrých skutků, zaznívající z činů [spojení] „lamy obětníka a patrona almužníka ${ }^{\text {"97 }}$ na ho-

92 Dřívější cangský král - jedná se o čtvrtého (a posledního) cangského krále Tänkjongwangpa (1621-1642). Viz též poznámku 42.

93 Sönamčhönphel - viz poznámku 69.

94 Čholkhasum - „Tři čholkhy“ neboli země. Tradiční dělení Tibetu na tři „povincie“: 1) Ücang (Centrální Tibet) - země Dharmy; 2) Dotä (Kham) - země s hojností lidí; 3) Domä (Amdo) - země koní.

95 Akšauhiní - indická armáda tvořená deseti aníkiní čili 21870 slony, 21870 vozy, 65610 koňmi a 109350 pěšáky. Viz M. MonierWilliams, A Sanskrit-English Dictionary, Oxford 1899, str. 4.

96 Thimzung - „dvojice zákonư“, blahodárné působení zákonů spojené světské a duchovní moci, když jsou ve vzájemném souladu.

97 Lama obětník a patron almužník - čhöjön, spojení duchovní moci, vykonávané církví, s podporou moci světské. Instituce čhöjön 


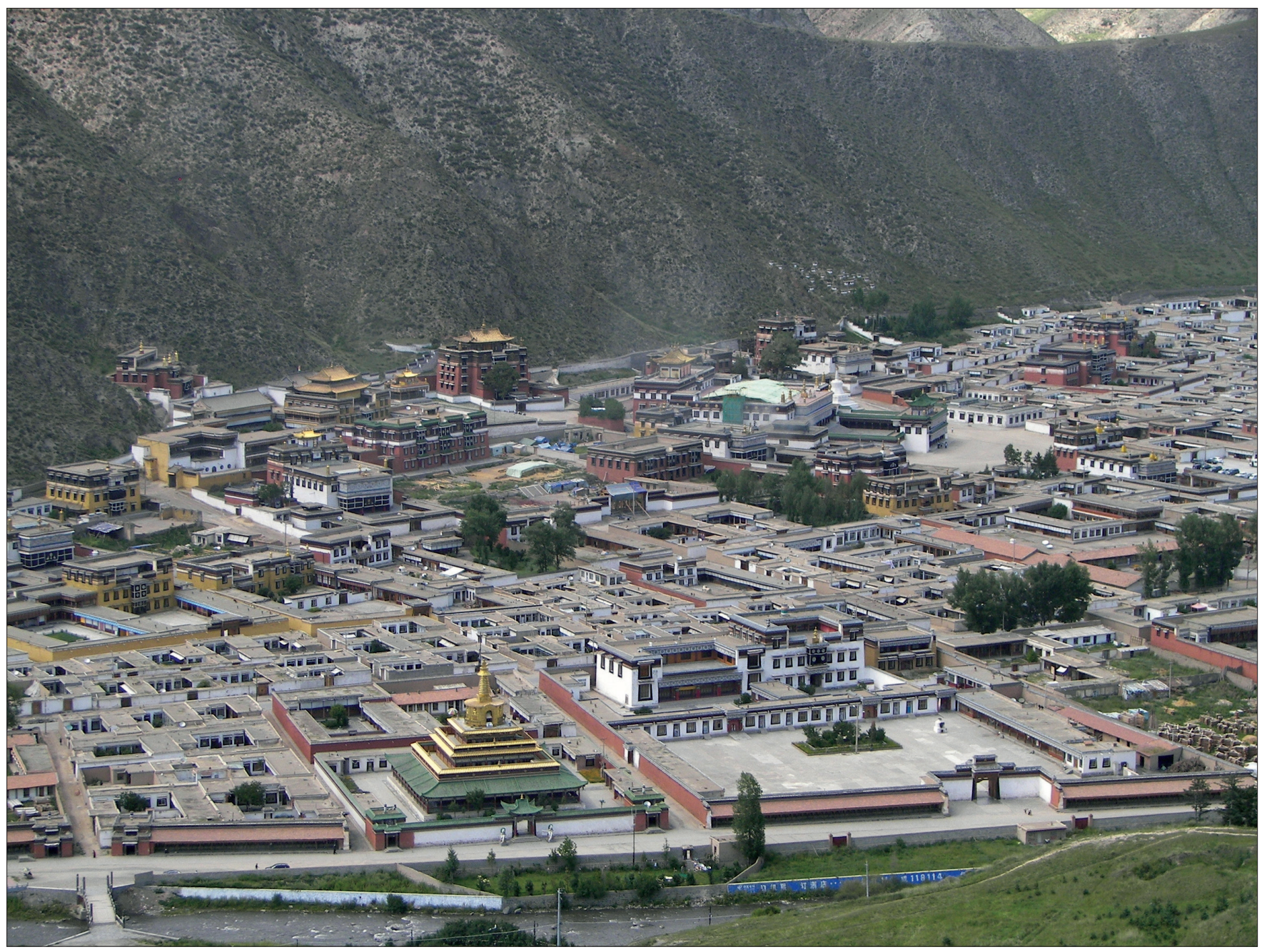

Obr. 16. Klášter Labrang Tašikhjil (čínsky La-pu-leng-s’ 拉卜楞寺) - jeden z nejvýznamnějších gelugpovských klášterů Amda ležící na jihu provincie Kan-su (Lin-sia 臨夏). Foto Jakub Hrubý.

rách ctnostné země Sněhem pokryté. Tak byl vztyčen praporec vítězství vše si podmaňujícího učení školy Gedän, soupeřící s vznešeností ŕriše bohů. Po celém Tibetu od Gangtese [na západě] až po Dokham [na východě ${ }^{98}$ stali se lidé dobrodinci školy Gelug a všem, lamům, klášterům, [všem] třídám bohů, mnišstvu a světskému lidu se dostalo svrchovaného blaha. Mnozí Tibetané tehdy říkali: „Všichni, kdo jsou nezávislí, jsou štastní; všichni, kdo závisí na jiných, jsou ubozí.“ Anebo [jinak]: „Úzkoprsý je ten, kdo neposkytne svobodu jiným.“

Sám král pomýšlel na dloudobý prospěch jiných. Aby odstra-

byla zavedena za Jüanů mezi duchovenstvem školy Sakja a mongolskými chány.

98 Gangtese, též Gangtise - název mytologické hory Méru či Suméru, tibetsky Rirab, bájné „Osy světa“. Ztotožňována s majestátní horou Kailás v západním Tibetu, sahající do výšky 6714 metrů a svými ledovci zásobující vodou čtyři asijské veletoky Sindhu, Satladž, Karnálí a Cangpo (Brahmaputra). - Dokham - společný název východního Tibetu (Dotä, Kham) a severovýchodního Tibetu (Domä, Amdo), tvořících součást tzv. „Velkého Tibetu“ (Böčhen). nil nenávist vůči Gedänpě, kdyby se znovu vyskytla, a [mohl] poskytnout vojenskou pomoc věřícímu lidu, mnišstvu a dobrodincům Gedänpy, zavedl, jak výše řečeno, tradici „tibetských králü " pro své vlastní potomstvo a sám jako první dosedl na královský trůn.

1644

V té době, v [mužském] roce Dřeva a Opice [1644], Li C'čcheng 李自成, ${ }^{99}$ jeden $\mathrm{z}$ šesti lupičů patrících do tlupy vládce z Thapuru(?) ${ }^{100}$ na hranicích, vedl přes Si-ning vojsko banditů

99 Li C’-čcheng 李自成 - Čínský vzbouřenec, který se v roce 1631 přidal k povstání svého strýce Kao Jing-sianga 高迎祥a po jeho smrti (1636) převzal velení povstaleckých vojsk, která se zmocnila Siningu 西寧 a v roce 1644 pronikla do Pekingu, kde ohrozila existenci dynastie Ming. Z Pekingu ho vytlačila až mandžuská vojska, která na pomoc Mingům přivolal zrádný čínský generál Wu San-kuej 吳三桂. Poté, co asi 40 dnů držel Peking, byl Li C'-čcheng v roce 1645 zabit v provincii Chu-pej 湖北.

100 Thapur - Z kontextu vyplývá, že se jedná o Li C'-čchengova strýce Kao Jing-sianga, zvaného Čchuang-wang 闖王, „Prudký 
a dorazil do Pekingu. Připraviv o vládu posledního čínského císaře Čchung-čena 崇禎, ${ }^{101}$ okupoval několik měsícư ${ }^{102}$ hlavní město. Tehdy jistý Čchung-čenův ministr Wu San-kuej 吳三桂 ${ }^{103}$ požádal o pomoc císaře mandžuských Nü-čenů 女真 [Džürdžedů], ${ }^{104}$ který byl potomkem Nurhačiho 努爾哈赤. ${ }^{105}$ Když potom jeho vojska a mandžuská armáda obklíčila Peking, oddíly vzbouřenců prchly [na západ] k hranicím a na trůn nastoupil první mandžuský císař Šun-č 順治. ${ }^{106}$

V [ženském] roce Ohně a Vepře [1647] se prohloubila roztržka mezi Cangem a Předním Tibetem.

1652

V [mužském] roce Vody a Draka [1652] se vydal Pátý dalajlama do Pekingu a v následujícím roce [1653] se do Tibetu vrátil. Od té doby byly Čína a Tibet v těsném spojení a Tibet od Ngari [na západě] dolů [na východ] přešel pod vládu císařu Číny.

1654

V [mužském] roce Dřeva a Koně [1654] Gušri[chan] zemřel ${ }^{107}$ a na královský trůn nastoupil jeho nejstarší syn Dajanchan. [Vládní] pečet’ mu byla předána $\mathrm{v}$ [mužském] roce Země a Psa [1658].

1662

V [mužském] roce Vody a Tygra [1662] usedl na trůn Kchangsi 康熙 (1661-1722), císař Maháčíny (Velké Číny).

1667

V [ženském] roce Ohně a Ovce [1667] vojska Kőkenúřanů obsadila čínské město Si-ning, ale když přitáhla velká čínská armáda ke Grong-langu(?), [Kőkenúrurané] se opět v pokoji [stáhli].

1671

V [ženském] roce Železa a Vepře [1671] se tibetským králem stal Ratna ${ }^{108}$ a udály se další věci, o kterých bude řeč níže.

král“, který rebelii v Šen-si v roce 1628 zahájil. Viz poznámku 99.

101 Čchung-čen 崇禎 - poslední mingský císař (1628-1644).

102 několik měsíců - Li C'-čcheng držel Peking pouze asi 40 dnů. Viz poznámku 99.

103 Wu San-kuej 吳三桂 - zrádný čínský generál, který umožnil vstup mandžuských vojsk do Pekingu, která zde pak založila mandžuskou dynastii Čching 清 (1644-1911). V roce 1674 se proti ní vzbouřil a založil vlastní dynastii Čou 周.

$104 N$ Nü-čen 女真, též Džürdžed - předchůdci kmene Mandžuů v severovýchodní Číně, jejichž císařem byl Nurchači (viz poznámku 105).

105 Nurchač $i$ 努爾哈赤 - zakladatel a první císař dynastie Ťin 金 (1616-1636) s posmrtným titulem Tchaj-cu 太祖 (1583-1626). Viz Couling 1917, 402.

106 Šun-č 順治 - 1644-1661, první císař mandžuské dynastie Čching.

107 Gušrichan - zemřel 17. dne 12. měsíce ženského roku Dřeva a Koně jedenáctého šedesátiletého cyklu [1654], což v gregoriánském kalendári odpovídá 24 . lednu 1655 . - Jeho syn a nástupce $D a-$ janchan byl u moci 1655-1668.

108 Ratna - „Klenot“, zrèmě domácí přízvisko nejstaršího syna a nástupce Dajanchanova Tändzin Dalajchana (1668-1701).
1674

Mezitím v [mužském] roce Dřeva a Tygra [1674] se pching-si čchin-wang] 平西親王 ${ }^{109} \mathrm{Wu}$ San-kuej, někdejší čínský Ralpačän („Vlasatec"), ${ }^{110}$ vzbouřil proti čínskému císaři, ale tato situace byla rychle vyřešena.

1679

V [ženském] roce Země a Ovce [1679] se Abar Sanggjägjamccho $^{111}$ stal regentem desi.

1683

V [ženském] roce Vody a Vepře [1683] se narodil [Šestý dalajlama] Cchangjanggjamccho. ${ }^{12}$

1685

V [ženském] roce Dřeva a Vola [1685] nastoupil [Cchangjanggjamccho] na dalajlamovský stolec. ${ }^{113}$

1686

$\mathrm{V}$ [mužském] roce Ohně a Tygra [1686], posledním roce jedenáctého šedesátiletého cyklu, se narodil Lama-rinpočhe z Mönu. ${ }^{114}$

Dále, moje rodiště Tholi na březích řeky Mačhu v Kökenúrsku, zabrala poprvé většina potomků velkého krále Gušriho, jeho deseti synů od tř́ královen, a jiní. [Tito potomci] jsou známi jako Barún-gar [„Pravokorouhevní] Öled’ané. Později byla postavena svatyně Cchabčhe(?).

Potom byl do Kőkenúrska poslán Mongol, Gomangský „lama v důchodu“ (lazur) Ngawang Thinlälhündub, kterému Pátý dalajlama udělil titul nomunchána. ${ }^{115}$ Když tam dorazil, svolal dohromady všechny úředníky $\mathrm{z}$ okolí kláštera Tagnago'usi ${ }^{116}$ při ústí [řeky] Šugšapätong(?) na horním Džulagu, ${ }^{117}$ který dřive drželi Džúngaři. Rozděliv zemi, přidělil každému místo k přebývání. Tak byly zřízeny „korouhve“ (gar) Pravá [Barún] a Levá [Džún]. Až do neklidného času v následujícím [žen-

109 pching-si čchin-wang 平西親王 - „princ pacifikátor západu“, titul udělený v roce 1662 císařem Kchang-si Wu San-kuejovi.

110 Ralpačän - narážka na Wu San-kueje, který si nechal růst dlouhé vlasy jako projev neposlušnosti k mandžuskému př́kazu, aby si Č́ínané vyholovali hlavu. Čtyřicátý první tibetský král Ralpačän („Vlasatý“), pověstný svou hřívou, panoval v letech 815-838.

111 Sanggjägjamccho - 1653-1705, byl regentem (desi) Tibetu v letech 1679-1703. Viz též poznámky 30 a 126. - Abar - zdvořilostní výraz pro „dítě“ bylo Sanggjägjamcchovo přízvisko.

112 Cchangjanggjamccho - Šestý dalajlama (1683-1706?), talentovaný básník, autor milostných čtyřverší Gullu, pověstný svým romantickým životem. Viz též poznámku 125 a dále Kolmaš 2010b, 46. 113 dalajlamovskýstolec - Šestý dalajlama byl uznán převtělencem svého předchůdce Pátého dalajlamy (1617-1682) tehdejším Pátým pančhenlamou Lozangješem (1663-1737).

114 Lama-rinpočhe - Lhabzangchanův (poznámka 123) Sedmý „lžidalajlama“ Ngawang Ješegjamccho (1707-1717), narozený v roce 1686 a do úřadu uvedený v roce 1707. - Mön (Mönjul) - kraj jihovýchodně od Lhasy v sousedství Bhútánu.

115 Nomunchán - mongolský titul „chán víry“, odpovídající tibetskému čhögjal („král Nauky“).

116 Tagnago’usi - pravděpodobně čínský Tu-lan-kuo-s’ 都蘭國寺 v Čching-chaji.

117 Džulag - čínské jméno řeky Ta-tchung-che. 
ském] roce Dřeva a Zajíce [1675], ${ }^{118}$ Žili všichni ve svornosti, lidí i zvířectva přibývalo, [všude] vládlo štěstí.

1697

V [ženském] roce Ohně a Vola [1697] dvanáctého šedesátiletého cyklu, když císař Kchang-si na okružní cestě po zemi projížděl městem Ning-sia 寧夏 a dorazil do Si-anu 西安, byl Tümed’an Čhagnadordže-tálama ${ }^{119}$ a jiní vysláni, aby přizvali [na setkání s císařem] Kőkenúrské úřednictvo. Současně byl tehdy vypraven [do Tibetu] také první Čangkja-chutuch$t u,{ }^{120}$ aby přinesl Šestému dalajlamovi [císařský] úřední výnos a pečet. Vůdcům Kőkenúrského území bylo řečeno: „Dostavíte-li se vzdát císaři poctu, bude to [pro vás] dobré." Oni [na ta slova] dali a do Si-anu se dostavili.

Císař tehdy předal pečet’ a titul čchin-wanga] 親王 nejmladšímu Gušrichanovu synovi Taši-báthurovi ${ }^{121}$ a jiným udělil postupně tituly tün-wanga 郡王, bejileho, bejiseho, günga a džasagha, ${ }^{122}$ jakož i předal [všem] hojné dary. Tak si Kőkenúřany poddal své moci a dobré vztahy mezi Číňany a Mongoly svázal zlatým poutem.

Tehdy někteři vůdcové, kteří se [původně] k setkání [v Sianu] nedostavili, jako Dajan-chungtajdž a jiní, přišli později do Pekingu. Lhabzang, ${ }^{123}$ který [do Pekingu] nešel, se v příštím [mužském] roce Země a Tygra [1698] odebral z Baročhugagu do Předního Tibetu a usadil se v místě, kde žili dřívější mongolští králové. ${ }^{124}$

1702

V [mužském] roce Vody a Koně [1702], kdy se byl před Pánem Dharmy [Pátým] Pančhen-rinpočhem Lozangješem [16631737] zřekl slibů mnišské discipliny [vinaja], žil Cchangjanggjamccho s ženou a počínal si jako světský vládce. ${ }^{125} \mathrm{~V}$ témže

118 neklidný rok 1675 - V tom roce císař Kchang-si nařídil Kőkenúrským Mongolům, aby vyslali vojsko proti vzbouřivšímu se Wu San-kuejovi (viz poznámku 103). V roce 1675 na Kökenúřany zaútočil Galdanchan (1644-1697), v letech 1676-97 vůdce džúngarských Mongolů.

119 Čhagnadordže-tálama - vrchní siningský 西寧 lama.

120 První Čangkja-rinpočhe - viz poznámku 3.

121 čchin-wang 親王 - čínský titul „dědičný princ I. tř́ídy“, udělený Gušrichanovu nejmladšímu synovi Taši-báthurovi v roce 1698.

122 císařské tituly - 1) tün-wang 郡王 - „princ II. třídy“; 2) bejile (čínsky pej-le 貝勒) - „princ III. třídy; 3) bejise (čínsky pej-c’ 貝子) - princ IV. třídy; güng (čínsky kung 公) - „císařský vévoda“; 5) džasagh (čínsky ča-sa-kche 札薩克), „náčelník“. Viz Couling 1917, 248-249.

123 Lhabzangchan - mladší Tändzin Dalajchanův (viz poznámku 108) syn, poslední chošúdský král Tibetu (1703-1717), za něhož došlo k džúngarské invazi do Lhasy.

124 Baročhugag - lokalita při Cchädamu na Tibetské náhorní plošině. Dřívější chošúdští králové Tibetu měli v kraji Dam jihovýchodně od jezera Tengrinúr své sídlo.

125 Cchangjanggjamccho - O „tajném“ soukromém životě Šestého dalajlamy po jeho odstavení $\mathrm{z}$ úřadu v roce 1706 koluje řada legend: o jeho tajné pouti do Khamu, poté do Centrálního Tibetu, Indie, Nepálu a jinam, 1716 měl pobývat v Alašanu, 1717 podnikl tajnou cestu do Pekingu, 1724 navštívil Urgu atd. Jeho „tajemný “ život se uzavřel v Alašanu v roce 1746. Viz Cybikov 1987, 18, 185-186; Klafkowski 1979. roce [1702] odešel [desi] Sanggjägjamccho $\mathrm{z}$ úřadu a uchýlil se do ústraní, ustanoviv regentem svého nejstaršího syna. ${ }^{126}$ 1703

I když byl Lhabzang v [ženském] roce Vody a Ovce [1703] uveden do postavení krále, nevycházel s regentem kvưli rozporům o prvenství zadobře.

1705

Královna Ccheringtaši se nechovala dobře, proto regent a další v prvním měsíci [téhož ženského] roku Dřeva a Ptáka [1705] předložili návrh odvézt ji do Lhabzangova okresu [v Damu], odkud by je [oba potom] eskortovali do Kőkenúrska. Tam však oni nešli.

[Lhabzang], aniž by se vydal do Kőkenúrska, shromáždil mezitím po příchodu do „Černých vod“ (Nagčhu) vojáky a v šestém měsíci s třemi oddíly vojsk vyrazil [na Lhasu]. \{Byla to vojska tamního krále z Gämothangu, vojska z průsmyku Gola, vedená Thugü-džajisangem, a z Tölungu, vedená jistým Ccheringem nebo Cchewanggjalmo\}. ${ }^{127}$

Veda je, dorazil s nimi do Goly, Gämothangu a Tölungu, kde vojska svedla lítý boj se [spojenými] početnými vojsky třinácti myriarchií Tibetu, Khamu a Ngari a Lhasu dobyla.

Sanggjampa prchl v koženém člunu do Gongkardzongu. ${ }^{128}$ $\{[$ Lhabzang]chanův generál Thugü-džajisang bojoval s regentovým [velitelem] Dordžerabtänem v průsmyku Gola a Thugüdžajisang Dordžerabtäna zabil. [Na místě] stojí mohyla, [označující tohoto člověka] za převtěleného démona\}.

Když byl [desi] královninými vojáky u Kjorlungu ${ }^{129}$ dopaden, byl „eskortován do drahocenné říše“, \{to jest, byl zavražděn jistým Barčhokha Dargjab cho'ušočhem(?)\}.

Co se týče jeho [totiž Lhabzangchana], nebylo prý - podle podání starších - pro jeho velkou moc Nejvyššího úředníka člověka více obávaného. Postrádaje stud, vydal špatné duchovní a světské zákony, které protiřečily [dosavadní praxi] „dvojí tradice“ lugzung. ${ }^{130}$ Tím se dopouštěl zločinů. Vzhledem k tomu si lze představit, že na Lhabzangchana později [musely] dopadnout některé květy předurčené za plody [jeho] skutků, konaných v blízkosti [chrámu] Džowo-rinpočheho. ${ }^{131}$ A tak se od této doby držel Lhabzangchan u královské moci [celých] dvanáct let [do roku 1717].

126 Sanggjägjamccho - dále zvaný též Sanggjampa, odešel z regentského úřadu v roce 1703, ustanoviv svým nástupcem svého nejstaršího syna. V roce 1705 byl zabit. Viz též poznámky 30 a 111. Dále Lange 1976. 127 Nagčhu - „Černé vody“, lokalita severně od Lhasy. - Gola průsmyk na sever od Lhasy. - Gämothang, též Gamothang - lokalita na řece Kjičhu východně od Lhasy. - Tölung - údolí při pravé straně Kjičhu západně od Lhasy.

128 Gongkardzong - tvrz a město nacházející se jihovýchodně od Lhasy na jižní straně řeky Cangpo. - Sanggjampa - jiné jméno regenta Sanggjägjamccha (viz poznámku 126).

129 Kjorlung, též Kjormolung - klášter na úbočí hory při jižní straně řeky Tölung západně od Lhasy.

130 lugzung - „dvojí tradice“, totiž respektování vzájemných závazků plynoucích ze vztahu světského knížete-dobrodince (jön) a duchovního lamy-obětníka (čhö). Viz poznámku 97.

131 Viz poznámku 84. 
1706

V [mužském] roce Ohně a Psa [1706] bylo rozhodnuto, že Cchangjanggjamccho nebyl [pravým] převtělencem tulkuem [Pátého] dalajlamy. Když potom on a synové [regenta] Sanggjampy byli z nařízení čínského císaře eskortováni dolů [do Číny], stalo se jistým, že Cchangjanggjamccho zemřel v Künganúru v horní části Kőkenúrska. Ostatní byli odvlečeni do Dolonnúru na čacharském území. ${ }^{132}$

1707

Podle předpovědi některých lamů a věštců-orakulů byl v [ženském] roce Ohně a Vepře [1707] na dalajlamovský stolec dosazen Ješegjamccho z Mönu [1707-1717]. ${ }^{133}$

1708

$\mathrm{V}$ [mužském] roce Země a Myši [1708] se v Lithangu v Khamu narodil [Sedmý] dalajlama Kalzanggjamccho [1708-1757].

1713

Někdy okolo [ženského] roku Vody a Hada [1713] se vedl spor o „Pravou“ a "Levou“ korouhev mezi Dajan-chungtajdžem ${ }^{134}$ a Cchecchen(?)-tajdžem, který krátce předtím přišel i se svým kmenem z Džúngarska a usadil se v „Levé korouhvi“. Tehdy poslal Pančhen-rinpočhe [jistého] Dordžedzinpa(?)-tulkua [prostředkovat], a Cchecchen-tajdž dostal [tehdy] „Pravou korouhev“.

1716

V [mužském] roce Ohně a Opice [1716] Kőkenúrští vůdcové pozvali künziga [„vševidoucího“] Kalzanggjamccha do velkokláštera Kumbumu, ${ }^{135}$ zbudovaného v místech, kde se narodil dželama [Congkhapa].

I když Lhabzangchan z Předního [Ü] a Zadního [Cang] Tibetu a džúngarský vůdce Cchewangrabtän-chungtajdž (16971727) dříve spolu dobře vycházeli, začal Lhabzang postupem doby tajně vyznávat starou víru. Dříve než po něm Šindžečhögjal [„Pán smrti“ Jamarádža] zatoužil, odeslal jako dar do Džúngarska [nějaké] psané kletby, [ukryté] v koňských sedlech a oděvech. Džúngarští, dovědouce se o doručovateli, \{jímž byl Tibetan, [Lhabzang]chanưv učitel [bagš $\left.]^{136}\right\}$, těchto sedmi(?) zakletých předmětů, vypravili v [ženském] roce Ohně a Ptáka [1717] z Džúngarska staršího Ccheringdönduba $^{137}$ a dalších pět generálů \{Čhönphela, Thobčhiho, Sanggjäa a Dugkar-džajisanga\} s vojskem, které přes Depanagcchong(?) a Lágän(?) dorazilo do Damu.

132 Künganúr - nevelké jezero jižně od Kőkenúru. - Dolonnúr - „Sedm jezer“, lokalita v Čacharsku na území dnešního Vnitřního Mongolska.

133 Ješegjamccho - viz poznámku 114.

134 Dajan-chungtajdž - Lhabzangchanův bratranec, náčelník Pravé korouhve v Kökenúrsku.

135 künzig - „Vševidouci“, stejně jako künkhjen („vševědouci“), jsou běžné zdvořilostí tituly dalajlamů. - Kumbum - gelugpovský velkoklášter v Čching-chaji při jezeře Kőkenúr, čínsky zvaný Tchaer-s' 塔爾寺, založený v roce 1588, rodiště reformátora Congkhapy. Viz Kolmaš 2009, 119-120.

136 bagš - učitel, název odvozený z čínského po-š” 博士, „doktor“.

137 Ccheringdöndub starší - bratranec džúngarského vůdce Cchewangrabtäna, svým vlivem druhý muž v Džúngarsku.
V té době, kdy i Lhabzang \{a syn hrdiny Thugü-džajisanga Dala-tajdž a Ašita(?)\} vyslali početná tibetská a mongolská vojska k utkání [s protivníkem], dostavil se [na místo] i Pančhen-rinpočhe Lozangješe a další k jednání o míru, avšak neuspěli.

Džúngarská vojska pronikla do Lhasy, Lhabzanga přemohla a předvedla mu pomíjivost [člověkova] života, [to jest usmrtila ho]. Cchokjedordže, náčelník depa z Tagce, byl jmenován regentem. ${ }^{138}$

1718 a 1719

Na ústní příkaz „vysokého lamy“ [lhabcüna] z Džúngarska Lozangphüncchoga byli v letech Země a Psa [1718] a Země a Vepře [1719] zabiti vysoký ňingmapovský lama Dordžedag-tulku a další. Klášterní kolej Namgjalling při Gandänphodangu ${ }^{139}$ a kláštery Dordžedag a Mindolling a další patřící pod dozor [kláštera] Samjä byly zbořeny. ${ }^{140}$ Mnišská pravidla [tř́i klášterů] Sera, Däpung a Gandän byla [znovu] zavedena. Všichni učení [lamové] se shromažd’ovali ve lhaské Khjamře ${ }^{141}$ a obnovili debaty o buddhistické logice [cchänňi]. Učenci byli řazeni podle svých odborných kvalifikací a ustanovováni na místa opatů (khänpů), profesorů (lobpönů) a byla jim prokazována nezměrná úcta.

Mezitím přišla zpráva, že Sedmý dalajlama se narodil v Lithangu $\mathrm{v}$ Khamu, \{také že První Džamjangžäpa ${ }^{142}$ se vrátil do své země\} a že Ješegjamccho byl načas umístěn na [lhaský] kopec Čagpori. ${ }^{143}$ Potom byl Päkardzin z Mönu eskortován přes Kham dolů [do Číny] a bylo mu nařízeno zůstávat v Džeholu v Mongolsku. ${ }^{144}$

138 Cchokjedordže - džúngarský vůdce Ccheringdöndub ustanovil v roce 1717 regentem (sakjongem, „ochráncem země“) v Tibetu tagceského depu Lhagjalrabtäna (zabit 1720). Cchokjedordže bylo jméno regentova otce.

139 Gandänphodang - dalajlamovský palác (phodang) v Däpungu, postavený z iniciativy Druhého dalajlamy Gendüngjamccha v letech 1518-1530.

140 Dordžedag - důležité klášterní stř̌edisko sekty Ňingma v Předním Tibetu mezi Samjä a Lhasou. - Mindolling - ňingmapovský klášter ležící jižně od Samjä za řekou Cangpo. - Samjä - starobylý klášter východně od Lhasy z 8 . století, tehdy v držení ňingmapovců. Viz poznámku 17. - Všechna tato tři místa, jako centra školy Ňingma, byla Džúngary, lítými pronásledovateli sekty „Červených čepic“ (Žamar) a horlivými stoupenci školy „Žlutých čepic“ (Žaser), devastována. Podrobněji o džúngarské invazi a okupaci Tibetu v letech 1717-1720 viz Petech 1972, kap. 3-4, 32-65.

141 Khjamra - hlavní nádvoři lhaské katedrály Džókhang (Džowökhang), sloužící jako shromaždiště mnichů při učených debatách.

142 První Džamjangžäpa - „Usmívající se Maňdžušri', vlastním jménem Ngawangcöndü, amdoský rodák (1648-1721), zakladatel kláštera Labrang (1709), autor rozsáhlého literárního díla. V Předním Tibetu pobýval od roku 1668 a do Amda se vrátil poprvé již v roce 1708 . Viz Chandra 1959, 28, 45-49; Cybikov 1987, 38; Kolmaš 2010b, 99.

143 Čagpori - „Železný kopec“, pahorek naproti Potale ve Lhase se známou fakultou tibetské medicíny (v roce 1959 padla za obět čínskému vandalství).

144 Päkardzin z Mönu - titul „Držitel bílého lotosu“ sedmého 


\section{0}

Když bylo künzigovi [Sedmému dalajlamovi] Kalzanggjamcchovi třináct roků, to bylo v [mužském] roce Železa a Myši [1720], byli všichni, kteří byli ve věcech vnějších i vnitřních otevřeně a neskrývaně jedné víry a jedné touhy, $\mathrm{z}$ rozkazu toho, jenž „otáčí kolesem moci“, ${ }^{145}$ [to jest vládne] nad východní částí světa [to jest císaře Kchang-si], vypraveni do Předního Tibetu (Ü) ve Sněžné zemi. Byli to tito: (I) z Pekingu - čtrnáctý císařův syn Jün-tchi 允祯 [s titulem] Cangtün čchin-wang 藏軍親王 ${ }^{146}$ a vysocí úředníci s vojskem [... a dalších sedm vysokých duchovních a světských hodnostářů]; (II) z Kőkenúrska - potomek ojratského Gušrichana Lozangtändzin čchin-wang, ${ }^{147}$ [... a dalších devět vysokých duchovních a světských hodnostářů]; (III) z Alašanu - Chalšan z Čingischánova rodu [s titulem] efu-bejile-báturdžunang ${ }^{148}$ [... a další tři vysocí duchovní a světští hodnostáři].

[Skupina] se postupně ubírala podél břehů jezera [Kőkenúr], Ňäncchor(?), Solomo, ${ }^{149}$ horního toku řeky Mačhu, [pohoří] Bajankaraula ${ }^{150}$ až $\mathrm{k}$ řece Dičhu. Dorazivši tam, Jün-tchi čchin-wang se svou družinou se vrátili nazpět. Když potom [výprava] dorazila nahoře do Dungbury, [k průsmyku] Dangla a do Bogšagu(?), narazila nečekaně na vojsko ojratských Džúngarů vracející se do své země. Ale k ničemu nedošlo. Načež od Cchomora(?), Nagčhu, Radengu, Taglungu a Phumda dospěli v Kjišö do Lhasy. ${ }^{151}$

Potom postupně uvedli [Sedmého dalajlamu] na „druhý

„lžidalajlamy“ Ješegjamccha, rodáka z Mönu (viz poznámku 114). Džehol - tibetsky Šehor, čínsky Že-che 熱河, dnes Čcheng-te 承德. Někdejší letní císařské město vzdálené asi 180 kilometrů severovýchodně od Pekingu v dnešní provincii Che-pej 河北(nikoli v Mongolsku!), s nákladnými stavebními napodobeninami lhaské Potaly a žikackého Tašilhünpa. Viz Kolmaš 2009, 159.

145 otáčet kolesem moci - tibetsky khorlö gjurwa, synonymum svrchovaného vládce čakravartina, ideálního panovníka, vládnoucího podle Buddhova učení. Kolmaš 2009, 114.

146 Jün-tchi 允禵 - tibetsky Žise, čtrnáctý syn císaře Kchang-si, žijící v letech 1688-1755. Měl titul Cang-tün čchin-wang 藏軍親王, „princ I. třídy, generál Tibetu“. Viz Petech 1972, kap. 5 (The Chinese Conquest of Tibet), 66-73.

147 Lozangtändzin - Gušrichanův vnuk, syn jeho desátého syna Taši-báthura Tändzinčhögjala (viz poznámky 12 a 175). O významné roli, kterou sehrál při vzniku čínského protektorátu v Tibetu v závěru vlády císaře Kchang-si a nástupu nové tibetské politiky císaře Jungčenga (1723-1735), viz Petech 1972, kap. 6 (The Chinese Protectorate during the last years of K'ang-hsi), 71-90, a kap. 7 (Tibet and the New Policy of Yung-cheng), 91-112.

148 Alašan - tibetsky Alagša, oblast severního Šen-si osídlená ordoskými Mongoly. - Efu-bejile-báturdžunang je mandžuský titul s významem „manžel císařské princezny“. Mayers 1897, 2 (poznámka 15).

149 Solomo, též Soloma - mongolský název pro úsek řeky Mačhu západně od jezera Caringnúr.

150 Bajankaraula - horský hřeben tvořící předěl horních toků řek Mačhu (Žlutá řeka) a Dičhu (Dlouhá řeka).

151 Dungbura - průsmyk jihozápadně od Dičhu. - Dangla - průsmyk v pohoří Thanglha. - Radeng - klášter školy Kadam severovýchodně od Lhasy (založen 1056).
Dudzin“, tibetskou Potalu, ${ }^{152}$ a [dosadili ho] na sengthi („lví trůn“) v däpungském Gandänphodangu. ${ }^{153}$ Byla to velká slavnost všech pěti smyslových požitků. ${ }^{154}$ [Dalajlama] byl nazván „korunní ozdobou“ Tibetu i Velkého Tibetu a Pánem [Buddhova] učení. Jeho věhlas naplňoval celý svět.

$\mathrm{V}$ některých pověstech se o lidech [z okolí] jezera [Kőkenúr] tradují [tyto] příběhy z těch dob:

„Během velkých slavností v Potale byli vysocí úředníci z Číny posazeni do prostředních řad a obřadně obsluhováni, zatímco naši Kőkenúřané byli posazeni dohromady do zadních řad a jídlo jim bylo servírováno $\mathrm{v}$ chvatu.

Za druhé, třebaže jsme [chtěli] život depy z Tagce [regenta Lhagjalrabtäna] zachránit, nikdo nám nenaslouchal a naše žádost vyzněla naprázdno.

Za třetí, přivedli jsme dalajlamu $\mathrm{z}$ Lithangu a vlastním úsilím ho dosadili na „lví trůn“. Toto sice bylo považováno za velkou věc, když to bylo potřeba, jindy to bylo znevažováno.

Navíc podle našeho názoru Gušrichanovi potomci byli od dávna ustanovováni tibetskými králi, proto by tomu tak mělo být i nyní. Přesto byl do funkce regenta desi dosazen Khangčhennä ze Šangu v Zadním Tibetu! ${ }^{155} \mathrm{~V}$ důsledku mnoha [takových] př́ípadů zalévá naše tváře pot hanby a do našich srdcí vniká trn. Jsouce [s tímto jednáním] nespokojeni, př́sahali jsme před ,Paládiem 'Sněžné země tibetské, ${ }^{156}$ že proti Číně zvedneme revoltu.“

Slyšel jsem, že [lidé, kteří] se vrátili do Kökenúrska, [o tom] říkali všemu lidu. Nicméně bojovat, at už proti Číně, nebo proti Tibetu, zvlášt když [náš lid] žije v zemi čínského císaře, by bylo bojovat s Čínou. [Jak praví] přísloví: „Démon [číhá u dveří] na východě, [a ty posíláš] výkupné [ke dveřím] na západě!“

1721

V [ženském] roce [Železa a] Vola [1721] se vrátili.

1722

Když se [v mužském] roce [Vody] a Tygra [1722] shromáždili, neujednotili se [ani] na dřívější přísaze, [ani] na vnitřních pořádcích.

1723

V [ženském] roce Vody a Zajíce [1723], kdy nastoupil na trůn čínský císař Jung-čeng 雍正, ${ }^{157}$ byla svolána [mongolská] vojska, at' už kvůli vnitřním, nebo vnějším nepokojům. Viděl jsem je na své cestě do [provincie] Ü v Tibetu. Následně,

152 Druhý Dudzin - „Druhý přístav“, jiný název dalajlamovského paláce ve Lhase.

153 Gandänphodang - viz poznámku 139. - Lví trůn - tibetsky sengthi, metaforické označení dalajlamovského stolce.

154 pět smyslových požitkư, tibetsky döjönnga - potěšení skýtané pěti smyslům - zraku, sluchu, čichu, hmatu a chuti.

155 Khangčhennä - „Z Khangčhenu“, zvaný též Khangčhenpa („Khangčhenský“), z údolí řeky Šangčhu východně od Žikace, vlastním jménem Sönamgjalpo. Pưvodně jeden z Lhabzangových ministrů a zároveň guvernér oblasti Ngari. V letech 1721-1727 předseda Rady ministrů-kalönů (nikoli regent-desi).

156 „Paládium“ - tj. Buddhova socha či čhörten.

157 Jung-čeng 雍正 - 1723-1735, třetí císař dynastie Čching. 
svářejíce se uvnitř [mezi sebou], napadla ve zmatku některé čínské pevnosti, avšak nerozumíce vojenským věcem, bylo to, jak když si děti hrají. Tehdy se do bojů o kontrolu nad tímto územím vložili dva čínští generálové ${ }^{158} \mathrm{~s}$ velkým vojskem. Rozprášeni, jako když se orel vrhne na hejno malých ptáčat, mongolští vůdcové prchli na sever a [jejich] vojsko se rozuteklo jinam.

Jako když je měsíc zastíněn [nějakou] mocí, i země se noří do stínu. V [ženském] roce Zajíce [1723] a

1724

v [mužském] roce Draka [1724] čínská vojska v Amdu zle poničila kláštery, meditační místa a špatně nakládala s [mnoha] vysokými lamy. Dokonce i v Pekingu se ukázala děsivá znamení na zemi, ${ }^{159}$ požáry a vichřice. Tehdy [Pátý] pančhen[lama] ${ }^{160}$ vyslal [do Pekingu] svého člověka. S tím byl srozuměn i Čangkja-tulku. ${ }^{161} \mathrm{Když} \mathrm{velmi} \mathrm{naléhavě} \mathrm{prosili} \mathrm{o} \mathrm{pomoc} \mathrm{pro}$ [amdoské] kláštery a meditační místa, setkali se u dharmarádže Velkého Jung-čenga s prrívětivým [pochopením].

1729

V [ženském] roce Země a Ptáka [1729] byly kláštery a meditační místa obnoveny [ $\mathrm{z}$ fondů císařovy] pokladny. Ten také nařídil zrušení pokladnou vybírané každoroční daně od klášterních komunit. Tento blahodárný nezměnitelný obyčej poskytování [státní podpory] se dobře osvědčil. Od té doby se v klášterech a meditačních místech úspěšně šírilo naslouchání výkladům [svatých písem] a Buddhovo učení se šířilo jako oceán. Díky zavedení dobrých zákonů se štěstí a podivuhodná sláva šiřily po celém Kőkenúrsku a Amdu.

Když jsem pobýval v Předním Tibetu v klášterní koleji Gomang, úřadoval tehdy jako regent (desi) Khangčhennä ze Šangu v Zadním Tibetu a jeho čtyřmi ministry (kalöny) byli Dordžegjalpo, Lumpanä a Ngabö Lozang, kteří pocházeli z Předního Tibetu, a mladší kalön Pholha-tajdž, který byl ze Zadního Tibetu. ${ }^{162}$

$158 d v a$ čínští generálové - Nien Keng-jao 年美堯, asi 1665-1726, "pacifikátor vzdálených končin“ - fu-jüan 撫遠. - Jüe Čung-čchi 岳鍾琪 - 1686-1754, „Ščchuanský místokrál“ - S’-čchuan tchi-tu 四川提督.

159 děsivá znamení na zemi - narážka na ničivé zemětřesení, které 30. zárí 1730 postihlo Peking, způsobilo velkou zkázu ve městě a jeho okolí a za obět mu padlo na sto tisíc obyvatel. Píše o tom i moravský misionář Karel Slavíček v dopise Štěpánu Soucietovi do Pařiže z 2. ř́ijna 1733. Viz K. Slavíček, Listy z Č́ny do vlasti a jiná korespondence s evropskými hvězdáři (1716-1735). Z latiny přeložil J. Kolmaš, Praha 1995, str. 161 a pozn. 204 na str. 245.

160 Pátý pančhenlama - Lozangješepalzangpo (1663-1737).

161 Čangkja-tulku - druhý pekingský Čangkja-chutuchtu Rolpädordže, jinak Ješetänpädönme či Lalitavadžra (1717-1786). Amdan, pozdější důvěrník císaře Čchien-lunga, brilantní lingvista ovládající čínštinu, tibetštinu, mongolštinu a mandžuštinu, jazykový revizor mongolského překladu Kandžuru a Tandžuru, editor slovníku S'-tchi Čching wen-tien (viz poznámku 4). O jeho životě a dílu viz Chandra 1959, 27, 38-45.

162 čtyři ministři - Pod Khangčhennä jako předsedou Rady ministrů-kalönů v letech 1721-1727 působili: Ngaphöpa Dordžegjalpo,
Lumpanä, zasažený v srdci pěti šípy [démona] Lüme-dagpa, ${ }^{163}$ tehdy ustavičně lamentoval: „Obecně řečeno, kdyby nebylo [oněch] tří velkoklášterů [Sery, Däpungu a Gandänu], ale zejména kolejí Gomang a Gjümä, ${ }^{164}$ vládlo by v Tibetu štěstí.“ Skutečně jsem to slyšel.

I když tři ministři z Předního Tibetu měli skrytý plán, nemohli s ním vyjít ven. Teprve, když Pholha-tajdž odešel do Pholhy v Zadním Tibetu, ${ }^{165}$ zosnovali svržení Khangčhenpy z regentského místa [ve skutečnosti z předsednictví Rady kalönů]. Následně ho před chrámem Džowa [ve Lhase] osmnáctého dne pátého měsíce [ženského] roku Ohně a Ovce dvanáctého šedesátiletého cyklu [1727] zabili. Bylo to dva roky před tím, co byly v [ženském] roce Země a Ptáka [1729] obnoveny $\mathrm{v}$ Amdu kláštery a meditační střediska.

Mezitím se Pholhawa („Pholhavský“) ve své tvrzi dozvěděl, že bylo vysláno zločinecké vojsko, [aby ho zabilo], a proto prchl, a i když ho pronásledovala velká armáda, unikl a získal spřátelená vojska Ngariského krále v Ladaku. ${ }^{166}$ [Tato vojska] spolu s armádou Zadotibetských téměř jeden rok sváděla bitvu s vojsky Předotibetských poblíž Gjanceské pevnosti. ${ }^{167}$ Na straně vojsk Předního Tibetu bojoval předotibetský hrdina Cchedag(?) a další, a na straně vojsk Zadního Tibetu byl velitel Julni(?) ze zadotibetského Ňašuru ${ }^{168}$ [a další]. Dvacátého osmého dne pátého měsíce [mužského] roku Země a Opice [1728] byli Předotibetané poraženi a tři kalöni a další \{celkem sedmnáct lidí\} byli zajati. Současně dorazili také úředníci a vojsko vyslaní císařem dharmarádžou Jung-čengem a ti, kdo se provinili, byli posláni do svých př́ǐtích životů [to jest byli popraveni].

Pholha-tajdž obdržel z císařova poručení titul tün-wanga, udělena mu pochvala a byl ustanoven „tibetským králem“ (bögjal). Od té doby pronásledování Gedänpy úplně ustalo a rozšírila se [praxe náboženských] výkladů, diskusí a písemné tvorby. ${ }^{169}$ Celé území Sněžné země se těšilo hojnosti štěstí.

Lumpanä Tašigjalpo a Džarawa Lodögjalpo - všichni z Předního Tibetu; a Pholhanä Sönamtobgjä ze Zadního Tibetu. Viz Petech 1972, 283.

163 Lüme-dagpo - doslova „Vlastník ne-těla“, epitet démona chlípnosti, nazývaného též „Držitel pěti šípư“ (Dangapa), totiž pomatenosti, roztouženosti, otupělosti, vyprahlosti, smrti.

164 Gomang - bohoslovecký dacchang v Däpungu (viz poznámku 16). - Gjümä - gelugpovská fakulta nižších tantrických studií, nacházející se v severovýchodní části Lhasy pobliž kláštera Meru.

165 Pholha - tvrz mezi Žikace a Gjance v Zadním Tibetu. Rodiště kalöna Pholhanä („Z Pholhy“), též Pholhawy („Pholhavský“) či Pholha-wanga Sönamtobgjä (viz poznámku 162), strůjce atentátu na předsedu Rady kalönů Sönamgjalpa (viz poznámku 155).

166 Ladak - území v údolí řeky Sindhu, ovládané Tibetany a dříve Tibetu patřící. Dnes je součástí indického svazového státu Džammú a Kašmír. - Ngariský král - ve skutečnosti guvernér nejzápadnější části Zadního Tibetu Ngari. Byl jím Cchetänrabdžam, starší bratr Khangčhennäův.

167 Gjance - město a tvrz v jižním Tibetu jihovýchodně od Žikace na řece Ňangčhu.

168 Ňašur - lokalita východně od Gjance.

$169 v y ́ k l a d y$, diskuse, písemná tvorba - tibetsky čhä, cö, com, běžná 


\section{8}

Později, to bylo v [mužském] roce Země a Draka třináctého šedesátiletého cyklu [1748], Dalajbátur, ${ }^{170}$ Pholha-wangưv mladší syn drsných mravů, zabral místo regenta [ve skutečnosti „krále“]. Jeho srdce však železným hákem držel [démon smrti Mára] Dü a stal se dokonce neprrítelem [Buddhova] učení. Zanedlouho však byl [v roce 1750] z císařova rozkazu usmrcen a jím tradice tibetských regentů (desiů) skončila. ${ }^{171}$ Po [Jung-čengovi] se chopil moci císař Čchien-lung a i v Tibetu nastal čas prosperity. V tom roce se narodil [Šestý] Pančhenrinpočhe Paldänješe, ${ }^{172}$ př̀evtělenec svého předchůdce. A v [mužském] roce Země a Tygra třináctého šedesátiletého cyklu [1758] přišel na svět Osmý dalajlama Džampalgjamccho. ${ }^{173}$

\section{9}

V [ženském] roce Země a Vola [1779] se künkhjen („vševědoucí) Pančhen[lama] vydal na cestu, aby lidem na východní straně hlásal buddhismus.

1780

V [mužském] roce Železa a Myši [1780] Pančhen-rinpočhe doputoval do Pekingu, sídelního města Číny. Díky zdvojenému duchovně-světskému vládnutí ve třech zemích - Číně, Tibetu a Mongolsku, [reprezentovanému] císařem Čchien-lungem, velkým vladařem, a Čangkja-rinpočhem, vlivným mistrem [Buddhova] učení, se naděje a touhy [lidí] naplňovaly [způsobem], který soutěžil s mocným „všesplňujícím klenotem“ (jižinnorbu). Po jedenačtyřiceti letech [ $\mathrm{v}$ úřadu se tento] pančhenlama z údolí smrti znovu vrátil do Tibetu mezi živé. ${ }^{174}$

1781

Když jsme se v [ženském] roce Železa a Vola [1781] doslechli, že v Zadním Tibetu přišel na svět [sedmý pančhenlamův] převtělenec, bylo to, jako když z vrcholků na východě zazárí mocné slunce a mysli nás všech se rozjasnily jako květ stolistého [lotosu].

Taši-báturwang, nejmladší z deseti [Gušrichanových] synů Tändzinčhögjal a jeho syn Lozangtändzin se se mnou setkali a projevili mi svou úctu. ${ }^{175}$ Pro toto [všechno] jsou jiná území

činnost tibetských lamů, tzn. byl v plném rozsahu obnoven náboženský život v zemi.

170 Dalajbátur - mongolský titul mladšího syna Pholhawova, „krále“ Gjurmenamgjala (mezi roky 1747-1750).

171 konec desiů - Po smrti „krále“ Gjurmenamgjala císař Čchienlung nařídil, aby byl Tibet spravován dalajlamou s pomocí Rady čtyř kalönů. Úřad a titul regenta desi byl zrušen. (Později používaný titul desi sloužil k označení lamy, který převzal funkci dalajlamovy agendy $\mathrm{v}$ době jeho nezletilosti.)

172 Šestý pančhenlama - Lozang Paldänješe (1738-1780), schopný diplomat a nadaný duchovní spisovatel. V roce 1780 pobyl krátce v Pekingu u císaře Čchien-lunga, který mu také udělil čestný titul pančhen-erdeni („vzácný veleučenec“). Jeho stručnou biografii viz Chandra 1959, 9, 22-23; Cybikov 1987, 258-259; Kolmaš 2010b, 91.

173 Osmý dalajlama - Džampalgjamccho (1758-1804).

174 Sedmý pančhenlama - Lozang Tänpäňima (1781-1853), který po ,jedenačtyřiceti letech“ (ve funkci) zemřel v roce 1780, se opět „vrátil mezi živé“, tj. převtělil se do osoby svého nástupce.

175 Taši-báturwang - nejmladší z Gušrichanových deseti synů nesrovnatelná s [Kőkenúrskem]. Podrobný rodokmen Gušrichanova potomstva vládnoucího tomuto území jsem sestavil ve své práci „Původ Nauky“, Čhödžung. ${ }^{176}$

1786

V současné době, v [mužském] roce Ohně a Koně tř̌ináctého šedesátiletého cyklu [1786] potomky Gušrichana, kteří žijí v Kőkenúrsku a v Alašanu, jsou tito:

A) Na pravé straně řeky Mačhu: wang 王 Ngawangdargjä, džasagh Lozangtändzin, džasagh Lumbum a tajdž Čhöpal.

B) Na levé straně řeky Mačhu: wang Sönamdordže, Gangkarwang, bejile Džigmeješe, bejise Cchokjedordže, güng Sönamtobgjä, güng Gendündöndub, güng Čhökjongkjab, džasagh Künzangcchering, džasagh Paldžor, džasagh Čhagdor, džasagh Bandhe, džasagh Norburinčhen, džasagh Dordže, Khurlugbejise Lozangcchetän, džasagh Lhakjab, džasagh Gendünkjab, Cchädam-džasagh Gandäntänkjong, džasagh Čhöcünkjab a džasagh Tašičhönphel.

C) Ostatní jsou: Džúngar-bejile Čhökjongkjab, Džúngar-bejise Čhimedawa, Chode-güng Tamdin, Torgút-džasagh Könčhog, džasagh Dolmakjab, džasagh Urgjän, džasagh Samdubgjamccho a Chalcha-džasagh Cchethar. - Ř́ká se, že dnes je tam třiatřicet chošúnů a sto a jeden sumy. ${ }^{177}$

D) V Alašanské korouhvi: Che-si čchin-wang Wangčhenpalbar a jeho bratři, kteří jsou güngy, a další [hodnostáři].

Dále jsou ještě güng Dordžecchetän, Thusa-lagčhi Cchewangdordže, Thusa-lagčhi Džigčhekjab a mnoho jiných tajdžů.

Necht’ výše vylíčené „Letopisy Kőkenúrska“ - Cchongöngji lurgjü, jsou jako právě vycházející kotouč měsíce v úplňku! Necht' všechny skutky lamů, králů, ministrů a lidu tří [zemí] - Číny, Tibetu a Mongolska, jsou jako jasné světlo pronikající otvory mezi nejkrásnějšími duhovými mraky pomalu se sunoucími oblohou!

Necht' vyprávění o potěšujících událostech této země jako chladivé paprsky odstraňuje horečnaté bolesti znavených myslí!

Necht̉ zároveň jasné paprsky světla prozařují temnotu [lidské] nevědomosti!

Necht' se tímto libě znějícím příběhem rozpučí v zahradách vodní lilie!

Necht' jsou [„Letopisy Kőkenúrska“] podivuhodnou podívanou, která nikdy neunaví zrak lidí, at zblízka či zdáli! Emaho! (Ó, jak skvělý [to př́běh Kőkenúrska!]) ${ }^{178}$

Tändzinčhögjal (1632-1714). - Lozangtändzin - Tändzinčhögjalův syn (viz poznámky 12 a 147). K setkání se Sumpa-khänpem došlo mezi roky 1712 (kdy nastoupil Sumpa-khänpo do noviciátu v Gönlungu) a 1714 (kdy Taši-báturwang zemřel).

176 Čhödžung - rozumí se Sumpa-khänpovo dílo Pagsam džönzang („Dobrý strom splňující přání) z roku 1748. Viz poznámku 20; dále Kolmaš 2010b, 102 a 114-115.

177 Chošún - mongolsky „prapor, korouhev“, menší územněsprávní jednotka pod ajmaky („kraji“). - Sum - mongolsky „šíp“, nejnižší územněsprávní jednotka u Mongolů v hierarchii ajmak chošún - sum.

178 Emaho! - citoslovce vyjadřující uznalý údiv: „Ó, jak skvělé!“ 


\section{LITERATURA}

Bičurin, I. (N. J.) (1833): Istorija Tibeta i Chuchunora, I-II. St. Petěrburg. Bira, Š. (1960): Mongolskaja tibetojazyčnaja istoričeskaja literatura (XVII-XIX $v v$.). Ulánbátar.

Bira, Š. (1975): Někotoryje novyje dannyje o Sumba-Chambo Išbalžire. Sovremennaja Mongolija (Ulánbátar), t. II (10), fasc. 20.

Cch'-chaj 辞海 [Encyklopedický slovník „Moře slov“], I-III (1987). Šanghaj. Couling, S. (1917): The Encyclopaedia Sinica. Shanghai: Kelly and Walsh.

Cybikov, G. C. (1987): Cesta k posvátným místům Tibetu. Z ruštiny přeložil Josef Kolmaš. Praha: Vyšehrad. 2. vyd. (2001), Praha: Argo.

Čang, I-sun 張怡䔉 (ed.) (1985): Bod-Rgja cchig-mdzod čhen-mo/Cang Chan ta cch'-tien 藏漢大辭典 [Velký tibetsko-čínský slovník], I-III. Peking.

Čung-chua žen-min kung-che-kuo ti-tchu-ti 中華人民共和國地圖集 [Atlas Cínské lidové republiky] (1957). Peking.

Dandaron, B. D. (1965): Opisanije tibetskich rukopisej i ksilografov Burjatskogo kompleksnogo naučno-issledovatel'skogo instituta, vypusk II. Moskva, 6-8.

Das, S. Ch. (1889): Life of Sum-pa Khan-po, also styled Yeśes-Dpal-hbyor, the author of the Rehumig (Chronological Table). Journal of the Asiatic Society of Bengal, LVIII. Part I. (History, Antiquities, \&c.), II, 37-39.

Das, S. Ch. (1902, 1951): A Tibetan-English Dictionary with Sanskrit Synonyms. Calcutta: Bengal Secretariat Book Depôt.

De Jong, J. W. (1967): Sum-pa mkhan-po (1704-1788) and his Works. Harvard Journal of Asiatic Studies, XXVII, 208-217.

Dge bšes Čhos kji grags pa/Ke-si Čchü-ča 格西曲札 (1957): Brda dag ming cchig gsal ba/Cang-wen cch'-tien 藏文辭典. [Tibetsko-čínský slovník]. Peking.

Dhondup, K. (1978): Gedun Chophel: the Man Behind the Legend. Tibetan Review, XIII (10), 10-18.

Dreyer, J. T. (1976): China's Forty Millions. Cambridge, Massachusetts and London, England: Harvard University Press.

Dungkar, L. K. (2002): Dung-dkar cchig-mdzod čhen-mo (Dungkar Tibetological Great Dictionary). Peking: China Tibetology Publishing House.

Filchner, W. (1954): Kumbum. Lamaismus in Lehre und Leben. Zürich: Rascher.

Howorth, H. H. (1876): History of the Mongols. Part I. London: Longmans, Green.

Chandra, L., ed. (1959): Dpag-bsam ljon-bzang, Part III. New Delhi (Śatapițaka, 8).

Chandra, L. (1963): Materials for a History of Tibetan Literature, I-II. New Delhi (Śata-pițaka, 28, 29).

Chopel, G. (1978): The White Annals (Deb-ther dkar-po). Translated by Samten Norboo. Dharamsala: Library of Tibetan Works \& Archives.

Jü, Tao-čchüan于道泉(1930): Cchangs dbjangs rgja mccho’i mgul glu [Cchangjanggjamcchovy Písně]. Academia Sinica, The National Research Institute of History and Philology, Series A, No. 5. Pej-pching 北平.

Kämpfe, Hans-Rainer (1976): Ni ma’i zer/Naran-u gerel. Die Biographie des 2. Pekinger lČang skya-Qutuqtu Rol pa’i rdo rje. St. Augustin (Monumenta Tibetica Historica, II/1).

Karmay, H. (1980): Dge-'dun Chos-'phel, the artist. In: M. Aris and Aung San Suu Kyi, eds., Tibetan Studies in Honour of Hugh Richardson. Warminster: Aris \& Philips, 145-149.

Klafkowski, P. (1979): The Secret Deliverance of the Sixth Dalai Lama as Narrated by Dharmatāla. Wien 1979 (Wiener Studien zur Tibetologie und Buddhismuskunde, Heft 3).

Kolmaš, Josef (1973): Tibetan Sources. In: D. Leslie et al. (eds.), Essays on the Sources for Chinese History. Canberra: Australian National University Press, 129-140.

Kolmaš Josef (1980): China’s Minority Nationalities (Some Statistical observations). Archív Orientální, 48 (1), 1-21.

Kolmaš, Josef (1982): Dge-'dun Chos-'phel (1905-1951): Artist, Scholar and Nationalistic Intellectual (From the history of Indo-Tibetan Cultural relations) In: Filipský, Jan, ed., Academician Vincenc Lesný and Indian Studies (Centenary Commemoration Volume). Praha, 121-136.

Kolmaš, Josef (1994): The Ambans and Assistant Ambans of Tibet (A Chronological Study). Archív orientální Supplementa VII. Prague.
Kolmaš, Josef (2009): Malá encyklopedie tibetského náboženství a mytologie. Praha: Libri.

Kolmaš, Josef (2010a): Mandžuský pětijazyčný vokabulář. Fragmenta Ioannea Collecta 12. Sv. Jan pod Skalou.

Kolmaš, Josef (2010b): Slovník tibetské literatury. Praha: Libri.

Kolmaš, Josef (2011): Stručná historie států - Tibet. Praha: Libri.

Kolmaš, Josef - Malina, Jaroslav (2005): Čína z antropologické perspektivy. In: Malina, Jaroslav, ed., Panoráma biologické a sociokulturní antropologie: Modulové učební texty pro studenty antropologie a "př́buzných" obori̊, 21. svazek. Edice Scientia Nadace Universitas. Brno: Akademické nakladatelství CERM - Masarykova univerzita v Brně - Nakladatelství a vydavatelství NAUMA.

Kolmaš, J. - Vančikova, C. P. (1990): Tibetologica Buryatica (A Contribution to the bibliography of Tibet). Archiv orientální, 58 (1), 60-75.

Lange, K. (1976): Die Werke des Regenten Sans rgyas rgya mco (1653-1705). Berlin.

Mackerras, C. (1995): China's Minority Cultures. New York: Palgrave Macmillan.

Martin, D. (1997): Tibetan Histories. A Bibliography of Tibetan-language Historical Works. London: Serindia Publications.

Mayers, W. F. (1897): The Chinese Government. A Manual of Chinese Titles Categorically Arranged and Explained, with an Appendix. Shanghai: Kelly \& Walsh Limited.

Mayers, W. F. (1924, reprint 1939): The Chinese Readers's Manual. Shanghai: American Presbyterian Mission Press.

Monier-Williams, Sir Monier (1899): A Sanskrit-English Dictionary. Oxford: Oxford Clarendon Press.

Nie, Čchung-čchi 聶崇岐 (1947): Man-kuan chan-š 滿官漢釋[Č́nské výklady mandžuských úředních titulů]. Yenching Journal of Chinese Studies, 32, 97-115.

Nietupski, P. K. (1999): Labrang. A Tibetan Buddhist Monastery at the Crossroads of Four Civilizations. Ithaca, New York: Snow Lion Publications.

Norboo, S. (1977): Life and Works of Gedun Chophel. Tibetan Review, XII (6), 12-13, 16 .

Petech, L. (1959): The Dalai-Lamas and Regents of Tibet: A Chronological Study. Toung Pao, XLVII, Livr. 3-5, 358-394.

Petech, L. (1966a): Notes on Tibetan History of the 18th Century. Toung Pao, LII, 261-292.

Petech, L. (1966b): Tibet. In: Handbuch der Orientalistik, Erste Abteilung, Fünfter Band, Fünfter Abschnitt: Geschichte Mittelasiens. Leiden / Köln 1966, str. 311-371, zejména str. 334 et seq. (IV. Die Theokratie).

Petech, L. (1972): China and Tibet in the 18th Century. 2. vydání. Leiden: Brill.

Pubajev, R. J. (1969): Buddijskaja kosmologija $v$ istoričeskom trude SumbaChambo „Drevo sozercanija“. MIFCA, vypusk 3.

Pubajev, R. J. (1971a): Voprosy tekstologii istoričekogo sočinenija SumbaChambo „Pagsam-Čžonsan“, in: Tibetica. Materialy tibetologičeskogo seminara. Ulan-Ude.

Pubajev, R. J. (1971b): Perevod iz istoričeskogo sočinenija Sumba-Chambo „Pagsam-čžonsan“. Vagin-Dara-Galba-Badra-Dana. MIFCA, vypusk 5.

Pubajev, R. J. (1974): Materialy po istorii Mongolii v trude „Pagsam-čžonsan“ Ješej-Balčžora In: Materialy i issledovanija po Mongolii. Ulan-Ude.

Pubajev, R. J. (1978): Osobennosti teksta istoričeskogo sočinenija SumbaChambo „Pagsam-čžonsan“ i ich interpretacija pri perevode In: Issledovanija po istorii i filologii Centralnoj Azii. Ulan-Ude.

Pubajev, R. J. (1981a): „Pagsam-čžonsan“ - Pamjatnik tibetskoj istoriografii XVIII veka. Novosibirsk.

Pubajev, R. J. (1991): Pagsam-džonsan: Istorija i chronologija Tibeta. Novosibirsk.

Pubayev, R. E. (1981b): The Historical Treatise APag-bsam lJon-bzang by Sum-pa mKhan-po (1704-1788). Peculiarities in the Text and their Interpretation in Translation. Transl. from the Russian by Stanley Frye. The Tibet Journal, VI (1), 14-23. - Viz Pubajev 1978.

Pubajev, R. J. (1991): Pagsam-džonsan: Istorija i chronologija Tibeta. Novosibirsk.

Richardson, H. (1978): Gedun Chophel's „Unfinished“. The White Annals (Deb-ther dkar-po) by Gedun Chophel. Tibetan Review, XIII (10), 19-22. Richardson, H. E. (1962): A Short History of Tibet. New York: E. P. Dutton. 
Rockhill, W. W. (1910): The Dalai Lamas of Lhasa and Their Relations with the Manchu Emperors of China (1644-1908). Toung Pao, XI, 1-104.

Serruys, H. (1958): Genealogical Tables of the Descendants of Dayan-Qan. Central Asiatic Studies, III, 20-27.

Schram, L. M. J. (1957): The Monguours of the Kansu-Tibetan frontier, Part II: Their religious life. Transactions of the American Philosophical Society, New Series, 47 (I), Philadelphia, 32-33.

Schwarz, M. (2010): Stručná historie států - Mongolsko. Praha: Libri.

Slobodník, Martin (2002a): Konštitutívne prvky identity Tibetanov v okrajových oblastiach - na príklade regiónu Amdo. Českýlid, 89 (4), 351-361.

Slobodník, Martin (2002b): Labrang: Tibetský buddhistický kláštor v socialistickej Č́ne (dokumenty a svedectvá). Bratislava: Lungta.

Stoddard, H. (1985): Le mendiant de l'Amdo. Paris: Societé d’ethnographie.

Sum-pa mkhan-po (1964): History of India. Edited by Ta-bla-ma. Delhi.

Sumpa Khanpo (1748): Phags jul rgja nag čhen po bod dang sog jul du dam pa’i čhos bjung cchul dpag bsam ldžon bzang [Dějiny buddhismu v Indii, Číně, Tibetu a Mongolsku, „Dobrý strom splňující přáni“")].

Sumpa Khanpo (1786): Mccho sngon gji lo rgjus sogs bkod pa'i cchangs glu gsar sňan [Letopisy Kökenúrska].

Šíma, J. - Luvsandžav, Č. (1987): Mongolsko-český a česko-mongolský kapesní slovník. Praha: Státní pedagogické nakladatelství.

Tarthang Tulku (2006): Starověký Tibet. Z angličtiny přeložil Josef Kolmaš. Praha: Vyšehrad.

Tibetská kniha mrtvých. Bardo thödol. Vysvobození v bardu skrze naslouchání (1991, 2008). Z tibetštiny přeložil Josef Kolmaš. Praha: Odeon.

Vostrikov, A. I. (1962): Tibetskaja istoričeskaja literatura. Moskva (Bibliotheca Buddhica, 32): Petěrburgskoje vostokoveděnije.

Wan, Kuo-ting 萬國鼎 (1958): Čung-kuo li-šs ti-nien piao 中國歷史紀年表 [Chronologické tabulky k dějinám Č́ny]. Peking: Šang-wu jin-šu-kuan 商務印書館.

Wylie, T. V. (1962): The Geography of Tibet According to the 'Dzam-glingrgyas-bshad. Roma (Serie Orientale Roma, 25).

Yang, Ho-Chin (1969): The Annals of Kokonor. Bloomington: Indiana University Publications. Uralic and Altaic Series, 106.

Žagabpa, W. D. (2000, 2008): Dějiny Tibetu. Z angličtiny přeložil Josef Kolmaš. Praha: Nakladatelství Lidové noviny.

\section{TRANSLITERACE TIBETSKÝCH VÝRAZŮ}

\section{A}

$\operatorname{Abar}(a$ bar)

Ačhi ( $a$ čhi)?

Akja (a skja)

Alagša (a lag ša)

Amdo (a mdo)

Amňemačhen ( $a$ mjes ma čhen)

\section{B}

Bandhe (ban dhe)

Barčhokha Dargjab cho’ušočhe (bar čho kha dar rgjab cho’u šo čhe)? bardo (bar do)

Baročhugag (ba ro čhu 'gag)

Beri (be ri)

Bö (bod)

Böčhen (bod čhen)

bögjal (bod rgjal)

Bogšag (bog šag)?

bön (bon)

Butön Rinčhendub (bu ston rin čhen grub)

C

Cang (gcang)

Cangpa (gcang pa)

Cangpo (gcang po)

Cchabčhe (cchab čhe)
Cchädam (cchwa'i 'dam)

Cchangjanggjamccho (cchangs dbjangs rgja mccho)

cchänňi (mcchan ňid)

Cchedag (cche bdag)

cchepagme (cche dpag med)

Cchering (cche ring)

Ccheringdöndub (cche ring don grub)

Ccheringtaši (cche ring bkra šis)

Cchetänrabdžam (cche brtan rab 'bjams)

Cchethar (cche thar)

Cchewangdordže (cche dbang rdo rdže)

Cchewanggjalmo (cche dbang rgjal mo)

Cchewangrabtän (cche dbang rab brtan)

Cchodüngön (mccho bdun dgon)

Cchogthu (cchog thu)

Cchokjaring (mccho skja ring)

Cchokjedordže (mccho skje rdo rdže)

Cchomora (mccho mo ra)?

Cchongöngji lurgjü (mccho sngon gji lo rgjus)

Cchongöngji lurgjü sog köpä cchanglu sar ñän (mccho sngon gji lo rgjus sogs bkod pa'i cchangs glu gsar sňan)

Cchongönpo (mccho sngon po)

Cchongoring (mccho sngo ring)

Cchoňingri (mccho sňing ri)

ci (rcis)

cikar (rcis dkar)

cinag (rcis nag)

cö (rcod)

com $($ rcom $)$

Congkha (cong kha)

Congkhapa Lozangdagpa (cong kha pa blo bzang grags pa) cünčhung (bcun čhung)

$\check{\mathrm{C}}$

Čagpori (lčags po ri)

Čangkja (lčang skja)

čhä (čhhad)

Čhagdor (phjag rdor)

Čhagnadordže-tálama (phjag na rdo rdže twa bla ma)

čhangčhub (bjang čhub)

Čhimedawa ('chi med zla ba)

čhö (mčhod)

Čhöcünkjab (čhos bcun skjabs)

Čhödžung (čhos 'bjung)

Čhögjal-namsum (čhos rgjal rnam gsum)

Čhogthu (čhog thu)

čhöjön (mčhod jon)

Čhökjigjalcchän (čhos kji rgjal mcchan)

Čhökjiwangčhug (čhos kji dbang phjug)

čhökjong (čhos skjong)

Čhökjongkjab (čhos skjong skjabs)

Čholkhasum (čhol kha gsum)

Čhöndzingenphel (čhos 'dzin dge 'phel)

Čhönphel (čhos 'phel)

Čhöpal (čhos dpal)

čhörten (mčhod rten)

Čone (čo ne)

Čoni (̌́o ni)

D

dacchang (grwa cchang)

dalajlama (twa la’i bla ma) 
Dala-tajdž (da la the dže)

Dam ('dam)

Dangapa (mda'lnga pa)

Dangla (ldang la)

Debther karpo (deb ther dkar po)

Debther Šelgjimelong (deb ther šel gji me long)

depa (sde pa)

Däpung ('bras spungs)

desi (sde srid)

Dičhu ('bri čhu)

Digung ('bri gung)

dilän (dris lan)

döjön nga ('dod jon lnga)

Dokham (mdo khams)

dol (grol)

Dolmakjab (sgrol ma skjabs)

Domä ( $m$ do smad)

Dönjödordže (don jod rdo rdže)

Dönjögjalpo (don jod rgjal po)

Dordže ( $r$ do $r d z ̌ e)$

Dordžecchetän (rdo rdže cche brtan)

Dordžedag ( $r$ do rdže brag)

Dordžedag-tulku ( $r$ do rdže brag sprul sku)

Dordžedzinpa-tulku (rdo rdže 'dzin pa sprul sku)

Dordžegjalpo (rdo rdže rgjal po)

Dordžerabtän (rdo rdže rab brtan)

Dotö (mdo stod)

Dü (bdud)

Dudzin (gru'dzin)

Dugkar-džajisang (gdugs dkar dže’i sang)

Dugpa ('brug pa)

Dungbura (dung bu ra)

Düsumkhjenpa (dus gsum mkhjen pa)

Dzačhu ( $r d z a$ čhu)

Dzamling čišä ('dzam gling spji bšad)

dzong (rdzong)

Džamjang ('džam dbjangs)

Džamjangžäpa ('džam dbjangs bžad pa)

Džampal ('džam dpal)

Džampalgjamccho ('džam dpal rgja mccho)

Džang ('džang)

Džarawa (sbjar ra ba)

dželama (rdže bla ma)

Džigčhekjab ('džigs bjed skjabs)

Džigmeješe ('džig med je šes)

Džigmesamtän ('džigs med bsam gtan)

Džigtengönpo ('džig rten mgon po)

Džókhang (džo khang)

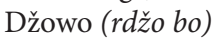

Džowökhang (džo bo’i khang)

Džowo-rinpočhe (džo bo rin po čhe)

Džulag ('džu lag)

\section{E}

emaho (e ma ho)

\section{G}

Gamothang (dga' mo 'phrang)

Gämothang (rgad mo 'phrang)

Gampopa (sgam po pa)

Gandän (dga' ldan)

Gandänpodang (dga' ldan pho brang)
Gandäntänkjong (dga' ldan bstan skjong)

Gangkar (gangs kar)

Gangtese (gangs te se)

Gangtise (gangs ti se)

Garu-locawa ('ga' ru lo ca ba)

gecchul (dge cchul)

Gedän (dge ldan)

Gedänpa (dge ldan pa)

Gelug (dge lugs)

Gelugpa (dge lugs pa)

Gendün Čhönphel (dge 'dun čhos 'phel)

Gendündöndub (dge 'dun don 'grub)

Gendüngjamccho (dge 'dun rgja mccho)

Gendünkjab (dge 'dun skjabs)

Gesar (ge sar)

Gjance (rgjal rce)

Gjümä (rgjud smad)

Gjurmenamgjal ('gjur med rnam rgjal)

Gokar (mgo dkar)

Gola (rgo/sgo la)

Gomang (sgo mang)

Gongkardzong (gong dkar rdzong)

Gönlung (dgon lung)

Gönlungčhamling (dgon lung bjams gling)

Gönlunggönčhen (dgon lung mgon čhen)

Gönlunggönpa (dgon lung dgon pa)

Gönpodong (mgon po gdong)

Gullu (mgul glu)

Gungthang (gung thang)

Guru Čhöwang (gu ru čhos dbang)

H

Hor (hor)

$\mathrm{CH}$

Cheši (hơ šsod)?

J

Jamdog (jar 'brog)

Jamdogccho (jar 'brog mccho)

Ješegjamccho (je šes rgja mccho)

Ješepaldžor (je šes dpal 'bjor)

Ješepaldžor Sumpa-pandita-khänpö Sungbumgji karčhag (je šes dpal 'bjor sum pa pandita mkhan po'i gsung 'bum gji dkar čhag)

Ješetänpädönme (je šes bstan pa’i sgron me)

jigkur (jig bskur)

jižinnorbu (jid bžin nor bu)

jön (jon)

Julni (jul ni)

Juthog Jöntängönpo (g.ju thog jon tan mgon po)

K

Kadam (bka' gdams)

Kagjü (bka' brgjud)

kalön (bka' blon)

Kalzangcchetän (bskal bzang cche brtan)

Kalzanggjamccho (bskal bzang rgja mccho)

Kandžur (bka' 'gjur)

Känlho (kan lho)

kar (dkar)

Karma (karma)

Karmakagjü (karma bka' brgjud) 
Karmapa (karma pa)

Khačhe (kha čhe)

Kham (khams)

Khangčhennä (khang čhen nas)

Khangčhenpa (khang čhen pa)

khänpo (mkhan po)

Khjamra ('khjam/khjams ra)

khorlö gjurwa ('khor los sgjur ba)

Khurlug (khur lug)

Kjangthanggang (rkjang thang sgang)

Kjičhu (skjid čhu)

Kjišö (skjid šod)

Kjorlung (skjor lung)

Kjormolung (skjor mo lung)

Könčhog (dkon mčhog)

Kongpo (kong po)

Kumbum (sku 'bum)

Künganúr (kun dga' no’ur)

künkhjen (kun mkhjen)

Künzangcchering (kun bzang cche ring)

künzig (kun gzigs)

L

Labrang (bla brang)

Ladak (la dwags)

Lágän (lwa rgan)?

Lama čhöpä čhoga (bla ma mčhod pa’i čho ga)

Lama-rinpočhe (bla ma rin po čhe)

lamän (bla sman)

Lamo (la mo)

Lamrim čhenpo (lam rim čhen po)

Langkarčän (glang dkar čan)

lazur (bla zur)

lhabcün (lha bcun)

Lhabzang (lha bzang)

Lhagjalrabtän (lha rgjal rab brtan)

Lhakjab (lha skjabs)

Lhasa (lha sa)

Lhokha (lho kha)

ling (gling)

Lingräpa Pämadordže (gling ras pa pad ma rdo rdže)

Lithang (li thang)

lobpön (slob dpon)

Lodögjalpo (blo gros rgjal po)

Lozang Čhökjigjalcchän (blo bzang čhos kji rgjal mcchan)

Lozang Čhökjiňima (blo bzang čhos kji ňi ma)

Lozang Paldänješe (blo bzang dpal ldan je šes)

Lozang Tändzingjamccho (blo bzang bstan 'dzin rgja mccho)

Lozang Tänpägjalcchän (blo bzang bstan pa'i rgjal mcchan)

Lozang Tänpäňima (blo bzang bstan pa’i ňi ma)

Lozangcchetän (blo bzang cche brtan)

Lozangcöndü (blo bzang brcon' 'grus)

Lozangdagpa (blo bzang grags pa)

Lozangješe (blo bzang je šes)

Lozangješepalzangpo (blo bzang je šes dpal bzang po)

Lozangphüncchog (blo bzang phun cchogs)

Lozangtändzin (blo bzang bstan 'dzin)

Lozangtänphel (blo bzang bstan 'phel)

luggi sogpa (lug gi sog pa)

lugzung (lugs zung)

Lumbum (klu 'bum)

Lüme-dagpo (lus med bdag po)
Lumpanä (lum pa nas)

lurgjü (lo rgjus)

M

mačhu ( $r m a \check{c h} u)$

mangdža (mang dža)

mänrampa (sman rams pa)

Marmedzä Ješe (mar me mdzad je šes)

Meru (rme ru)

Mindolling (smin grol gling)

Mön (mon)

Mönjul (mon jul)

Mönlam-čhenpo (smon lam čhen po)

Mönpa Päkardzinpa (mon pa pad dkar 'dzin pa)

\section{$\mathbf{N} / \check{\mathbf{N}}$}

Načhen (sna čhen)

nag (nag)

Nagčhu (nag čhu)

Ňagčhu (řag čhu)

Namccho (gnam mccho)

Namgjalling (rnam rgjal gling)

Ň̈ncchor (gňan cchor)

Ňangčhu (řang/mjang čhu)

Ň̈̈ngag (š̌an ngag)

Ňašur (ňa šur)

Ngabö Lozang (rnga bod blo bzang)

Ngagrim čhenpo (sngags rim čhen po)

ngapa (lnga pa)

Ngapa-čhenpo (lnga pa čhen po)

Ngaphöpa (nga phod pa)

Ngari (mnga' ris)

Ngawang Čhökjigjamccho (ngag dbang čhos kji rgja mccho)

Ngawang Ješegjamccho (ngag dbang je šes rgja mccho)

Ngawang Lozangčhödän (ngag dbang blo bzang čhos ldan)

Ngawang Lozanggjamccho (ngag dbang blo bzang rgja mccho)

Ngawang Thinlälhündub (ngag dbang 'phrin las lhun grub)

Ngawangcöndü (ngag dbang brcon 'grus)

Ngawangčhödän (ngag dbang čhos ldan)

Ngawangdargjä (ngag dbang dar rgjas)

Nimagjalcchän (ňi ma rgjal mcchan)

Ňingma (rňing ma)

Ňingmapa (rňing ma pa)

Norburinčhen (nor bu rin čhen)

\section{$\mathbf{P}$}

Pagsam džönzang (dpag bsam ldžon bzang)

Päkardzin (pad dkar 'dzin)

Paldänješe (dpal ldan je šes)

Paldžor (dpal 'bjor)

pančhenlama (pan čhen bla ma)

Pari (dpa' ri/ris)

Patulčän (dpa' rtul čan)

phodang (pho brang)

Pholha (pho lha)

Pholha-wang (pho lha wang)

Pholhanä (pho lha nas)

Pholhawa (pho lha ba)

phowa ('pho ba)

Phumdo (phu mdo)

Phüncchognamgjal (phun cchogs rnam rgjal)

phur (phur) 
Phurccha-gampa Čhödordže (phur ccha sgam pa čhos rdo rdže) Potala ( po ta la)

R

rabčhung (rab bjung)

rabdžampa ( $r a b$ 'bjams pa)

Radeng (rwa sgreng)

Ralpačän (ral pa čan)

Rawaphugpočhe (ra ba phug po čhe)

Rirab (ri rab)

Rolpädordže (rol pa’i rdo rdže)

\section{$S$}

Sadam (sa dam)

Sakja (sa skja)

sakjong (sa skjong)

Samdubgjamccho (bsam 'grub rgja mccho)

Samjä (bsam jas)

Samtänling (bsam gtan gling)

Sanggjä (sangs rgjas)

Sanggjägjamccho (sangs rgjas rgja mccho)

Sanggjampa (sangs rgjam pa)

Semňi (sem ňi $)$ ?

sengthi (seng khri)

Sera (se ra)

Seri (se ri)

Sogjul (sog jul)

Sönamčhönphel (bsod nams čhos 'phel)

Sönamdordže (bsod nams rdo rdže)

Sönamgjalpo (bsod nams rgjal po)

Sönamgjamccho (bsod nams rgja mccho)

Sönamtobgjä (bsod nams stobs rgjas)

Songcängampo (srong bcan sgam po)

sorig (gso rig)

Sorig gjüži (gso rig rgjud bži)

Sumpa (sum pa)

Sumpa-khänčhen (sum pa mkhan čhen)

Sumpa-khänpo (sum pa mkhan po)

sumtag (sum rtags)

sungbum (gsung 'bum)

$\check{S}$

Šädubling (bšad grub gling)

Šang (řangs)

Šangčhu (šangs čhu)

Šehor (gše hor)

Šerab ňingpo (šes rab sňing po)

Šerabgjamccho (̌̌es rab rgja mccho)

Šingdže-čhögjal (gšin rdže čhos rgjal)

Šugšapätong (šug ša pad stong)

\section{T}

tačä (rta dpjad)

Tagce (stag rce)

Tagcedzong (stag rce rdzong)

Tagcepa (stag rce pa)

Tagccher (stag ccher)

Tagccher-rinpočhe (stag ccher rin po čhe)

Taglung (stag lung)

Tagnago’usi (stag sna go’u si)

Tamdin (rta mgrin)

tändzinčhögjal (bstan 'dzin čhos rgjal)
Tändzingjamccho (bstan 'dzin rgja mccho)

Tandžur (bstan 'gjur)

Tänkjongwangpo (bstan skjong dbang po)

Tänpädönme (bstan pa’i sgron me)

Taši-báthur (bkra šis pwa thur)

Taši-báturwang (bkra šis pwa thur wang)

Tašičhönphel (bkra šis čhos 'phel)

Tašigjalpo (bkra šis rgjal po)

Tašikhjil (bkra šis 'khjil)

Tašilhünpo (bkra šis lhun po)

Tašipal (bkra šis dpal)

Tašizilnön (bkra šis zil gnon)

terma (gter ma)

Thanglha (thang lha)

thikor-čusum (khri skor bču gsum)

thimzung (khrims zung)

Thitamarčän (khri rta dmar čan)

Thobčhi (thob čhi)

Tholi (tho li)

Thubčhenling (thub čhen gling)

Thubtän Džigmenorbu (thub bstan 'džigs med nor bu)

Thugü-džajisang (thu gwus dže'i sang)

Thukwan (thu'u kwan)

Thusa-lagčhi (thu sa lag čhi)?

Tölung (stod lung)

tongpaňi (stong pa ňid)

Tönpäňima (bstan pa’i ňi ma)

tulku (sprul sku)

$\mathbf{U} / \ddot{\mathbf{U}}$

Ü (dbus)

Ücang (dbus gcang)

uma (dbu ma)

Urgjän (u rgjan)

V

Vaidúrja serpö melong (bai dwu rja ser po’i me long)

W

Wangčhenpalbar (dbang čhen dpal 'bar)

$\check{\mathbf{Z}}$

Žamar (žwa dmar)

Žaser (žwa ser)

Žikace (gžis ka rce)

Žise ( $\check{z} i s e)$

žulän (žu lan) 


\section{AUTOR}

Kolmaš, Josef (6. 8. 1933, Těmice u Hodonína), český sinolog a tibetolog, sociokulturní antropolog, překladatel. Emeritní ředitel Orientálního ústavu Akademie věd České republiky v Praze (1994-2002) a emeritní profesor Masarykovy univerzity v Brně. Po gymnazijních studiích na Velehradě a v Kyjově (1945-1952) absolvoval v letech 1952 až 1957 obory čínština a dějiny Dálného východu na Filologické fakultě Univerzity Karlovy v Praze a v letech 1957 až 1959 tibetský jazyk a literaturu na Ústředním národnostním ústavu v Pekingu. Od roku 1959 do roku 2003 působil v Orientálním ústavu, kde v letech 1961-1964 absolvoval interní vědeckou aspiranturu v oboru tibetanistiky. Působil jako Visiting Lecturer na Australian National University v Canbeře (1966), byl profesorem tibetštiny na Státní jazykové škole v Praze (1975-1994); v roce 1997 se habilitoval v oboru antropologie na Přírodovědecké fakultě Masarykovy univerzity v Brně (Antropologické struktury zemí východní a vnitřní Asie a jejich místo $v$ současném světě: Fenomén sociokulturního přenosu), v roce 2003 byl jmenován profesorem antropologie na Masarykově univerzitě v Brně. V letech 1994-2003 byl členem redakčních rad Archivu orientálního a Nového Orientu. Je členem International Association for Tibetan Studies (1979), European Association of Chinese Studies (1990). V letech 1993-2001 byl členem Vědecké rady Akademie věd České republiky v Praze. Od roku 1998 je členem ediční rady Edice Scientia Nadace Universitas Masarykiana v Brně, od roku 2003 členem Vědecké rady Filozofické fakulty Univerzity Palackého v Olomouci, od roku 2004 je členem redakční rady časopisu Univerzitní noviny (Brno).

V odborné práci se zabývá sociokulturní antropologií a politickými a kulturními dějinami Číny a Tibetu, tibetskou historiografií, klasickou tibetskou a čínskou literaturou, tibetským buddhismem a bibliografií tibetského a tibetologického písemnictví. Překládá z čínštiny, tibetštiny a některých evropských jazyků. Publikoval u nás i v zahraničí řadu vědeckých knih, překladů a odborných statí, mimo jiné Bibliography of Sino-Tibetan Languages [Bibliografie sino-tibetských jazyků], sv. 2 (Wiesbaden 1963, spoluvydavatel); Tibet and Imperial China: A Survey of Sino-Tibetan Relations up to the End of the Manchu Dynasty in 1912 [Tibet a císařská Čína: Výzkum sino-tibetských vztahů do konce mandžuské dynastie v roce 1912] (Canberra 1967); A Genealogy of the Kings of Derge (Sde-dge'i rgyal-rabs) [Genealogie králů Derge] (Prague 1968); Tibetan Manuscripts and Blockprints in the Library of the Oriental Institute Prague [Tibetské rukopisy a tisky v knihovně Orientálního ústavu v Praze] (Prague 1969); Prague Collection of Tibetan Prints from Derge, I-III [Pražská sbírka tibetských tisků z Derge] (Wiesbaden - Prague 1971-1996); Mezinárodní konference o otázkách statutu a hranic Tibetu (Simla, 1913-1914) (Praha 1975); Tibetan Books and Newspapers (Chinese Collection) with Bibliographical Notes [Tibetské knihy a noviny /čínská kolekce/ s bibliografickými poznámkami] (Wiesbaden - Prague 1978); The Iconography of the Derge Kanjur and Tanjur [Ikonografie dergeského Kandžuru a Tandžuru] (New Delhi 1978, 2002); ABC cestovatelü, mořeplavců, objeviteli (Praha 1979, ve spolupráci s Ivanem Hrbkem); Ferdinand Stoliczka (1838-1874): The Life and Work of the Czech Explorer in India and High Asia [Ferdinand Stoliczka /1838-1874/: Život a dílo českého badatele v Indii a Střední Asii] (Wien 1982); Chinese Studies on Tibetan Culture [Čínské výzkumy tibetské kultury] (New Delhi 1983); The Ambans and Assistant Ambans of Tibet (A Chronological Study) [Ambanové a zástupci ambanů v Tibetu /Chronologická studie/] (Prague 1994); Buddhistická svatá písma. Šestnáct arhatů (Praha 1995); Svět tibetského buddhismu (Praha 1996, spoluautor); Vzpomínka na Tibet / Recalling Tibet (Prague: Práh, 1997, spoluautor); Tibet: Dějiny a duchovní kultura (Praha 2004); Suma tibetského písemnictví (Praha 2004); Slovník tibetské literatury (Praha 2010); Stručná historie států - Tibet (Praha 2011). Pro edici Panoráma biologické a sociokulturní antropologie napsal 11. svazek Tibet $z$ antropologické perspektivy (2002), 12. svazek Smrt a pohŕbívání u Tibetanů (2003), 16. svazek První Evropané ve Lhase (1661) (Kircherovo résumé Grueberovy cestovní zprávy. Latinský text a český překlad) (2003) a 21. svazek (s Jaroslavem Malinou) Čína z antropologické perspektivy (2005). Autorsky se podílel na projektu Kruh prstenu: Světové dějiny sexuality, erotiky a lásky od počátkư do současnosti v reálném životè, krásné literatuře, výtvarném umèní a dílech českých malíru a sochařu inspirovaných obsahem této knihy, 1: „Celý svět" kromè euroamerické civilizace (2007). Překlady z čínštiny: Po Tüi-i, Drak z černé tůně (Praha 1958, 1964, v básnické spolupráci s J. Štroblovou); Fa-sien, Zápisky o buddhistických zemích (Praha 1972, 1995); Po Ťü-i, Datlovník v meruňkovém sadu (Praha 1996, v básnické spolupráci s J. Štroblovou); Süan-cang, Zápisky o západních krajinách za Velkých Tchangů (Praha 2002). Překlady z tibetštiny: Bajka o ptácích a opicích (Praha 1965); Černý mrak $v$ bilém. Tibetská lidová poezie (Praha 1976, Ostrava 2000, v básnické spolupráci s J. Štroblovou); Tibet, v knize Prameny života. Obraz člověka a světa ve starých kulturách (Praha 1982, s novým názvem Duchovni prameny života. Stvoření světa ve starých mýtech a náboženstvích, Praha 1997); Sakja-pandita, Pokladnice moudrých rčení (Praha 1984, 1988, v básnické spolupráci s J. Štroblovou); Tibetská kniha mrtvých. Bardo thödol. Vysvobození v bardu skrze naslouchání (Praha 1991, 1995, 1998, 2001, 2004; též ve slovenském překladu, Tibetská kniha mŕtvych, Praha 1998); Jádro transcendentální moudrosti (Praha 1992); Nangsa Öbum. Mystérium o životě a zmrtvýchvstání krásné paní Nangsy (Praha 1993); Sönam Gjalcchän, Zrcadlo králu․ Tibetská kronika 14. století (Praha 1998). Překlady z ruštiny: Čína. Čínský jazyk (Praha 1957, spolupřekladatel); G. C. Cybikov, Cesta k posvátným místům Tibetu (Praha 1987, 2001). Překlady z angličtiny: XIV. dalajlama, O Tibetu a tibetském buddhismu (Praha 1992, spolupřekladatel); Svoboda v exilu. Autobiografie 14. dalajlamy (Praha 1992, 2011); Roy Willis, Mytologie světa. Ilustrovaný prưvodce (Praha 1997, spolupřekladatel); W. D. Žagabpa, Dějiny Tibetu (Praha 2000); Tarthang Tulku, Starověký Tibet (Praha 2006). Překlady z latiny a francouzštiny: Karel Slavíček, Listy z Číny do vlasti a jiná korespondence s evropskými hvězdáŕi (1716-1735), Praha 1995 (překlad do čínštiny, Čung-kuo laj-sin [Listy z Č́ny], Čeng-čou 2002). Překlady z němčiny: Lexikon východní moudrosti. Buddhismus, hinduismus, taoismus, zen (Praha - Olomouc 1996, spolupřekladatel). Odborný editor cestopisných a jiných knih o Tibetu, autor odborných úprav, předmluv, doslovů, poznámek apod.: Arnošt Černík, Trůny bohů. K nebetyčným štítům Himálaje (Praha 1964, 1972); Láma Yongden [Lama Jongdän] a Alexandra David-Néelová, Mipam, lama s Paterou moudrostí (Praha 1969, 1990, Kutná Hora 2000); Evariste-Régis Huc, Cesta do Lhasy (Praha 1971, s novým názvem Putování Tibetem L. P. 1845-1846, Praha 2002); Heinrich Harrer, Sedm let v Tibetu: Mưj život na dvoře dalajlamy (Praha 1972, 1998); Ippolito Desideri, Cesta do Tibetu (Praha 1976, 2001); W. Y. Evans-Wentz, Milaräpa. Velký tibetský jógin (Praha 1996); Helmut Uhlig, Tibet. Tajemná země na střeše světa (Praha 2002); Patrick French, Tibet, Tibet. Historie ztracené země (Praha 2004); Fosco Maraini, Skrytý Tibet (Praha 2005). Josef Kolmaš je držitelem medaile Körösi Csoma Sándora (Budapest, 1984), Zlaté plakety Františka Palackého (Akademie věd ČR, 1993), několika nakladatelských cen ad. K 70. narozeninám mu byl věnován sborník Studia Sinica et Tibetica (Dedicated to Josef Kolmaš to His $70^{\text {th }}$ Birthday). Archiv orientální, roč. 71, 2003, č. 3, s. 245-489. A dále Martin Slobodník (2003): Vedecká dráha na pomedzí sinica a tibetica - k životnému jubileu profesora Josefa Kolmaša. Studia Orientalia Slovaca, 2, s. 23-27 (Bratislava).

Kontakt: Prof. PhDr. Josef Kolmaš, DrSc., Čihákova 30, 19000 Praha 9, telefon: 284823782. 